\title{
ПРОДОЛЖИТЕЛЬНОСТЬ И ГЕОДИНАМИКА ФОРМИРОВАНИЯ АНГАРО-ВИТИМСКОГО БАТОЛИТА: ПО ДАННЫМ U-Pb ИЗОТОПНОГО LA-ICP-MS ДАТИРОВАНИЯ МАГМАТИЧЕСКИХ И ДЕТРИТОВЫХ ЦИРКОНОВ
}

Хубанов В. Б., Цыганков А. А., Бурмакина Г. Н.

\begin{abstract}
Аннотация
В статье приведены результаты U-Pb (LA-ICP-MS) датирования детритовых цирконов из аллювиальных отложений р. Ангаракан (Северо-Муйский хребет, Северное Прибайкалье), водосборный бассейн которой сложен в основном гранитоидами баргузинского комплекса, типоморфного для позднепалеозойского Ангаро-Витимского батолита. В изученной популяции обломочных цирконов установлено три возрастных кластера с пиками 728, 423 и 314 млн. лет. Показано, что источником неопротерозойских и раннепалеозойских цирконов являются небольшие останцы магматических и метаморфических пород, вероятно подобные крупным провесам кровли АВБ, закартированным за пределами водосборного бассейна. Позднепалеозойский кластер включает два сближенных пика с возрастом 314 и 285 млн. лет, которые полностью «перекрываются» с временем формирования АВБ и указывают на гранитоидный источник цирконов. Данные детритовой геохронологии, в совокупности с данными по коренным источникам, указывают на длительное, около 40 млн. лет, формирование Ангаро-Витимского батолита, однако вопрос об интенсивности магматизма в течение этого времени требует дополнительных исследований. На основе анализа опубликованных геологических, геохимических и геохронологических данных предполагается, что формирование Ангаро-Витимского батолита происходило в результате плюм-литосферного взаимодействия, начавшегося в обстановке тектонического сжатия и сменившегося на рубеже 305 - 300 млн. лет (граница карбона и перми) растяжением, обусловившим смену «коровых» гранитоидов, гранитоидами, образованными за счет смешанного мантийно-корового источника.
\end{abstract}

\section{Ключевые слова:}

U-Pb геохронология, LA-ICP-MS, детритовый циркон, современный аллювий, Ангаро-Витимский гранитоидный батолит, SLIP, Северное Прибайкалье 


\title{
ПРОДОЛЖИТЕЛЬНОСТЬ И ГЕОДИНАМИКА ФОРМИРОВАНИЯ АНГАРО- ВИТИМСКОГО БАТОЛИТА: ПО ДАННЫМ U-РЬ ИЗОТОПНОГО LA-ICP-МS ДАТИРОВАНИЯ МАГМАТИЧЕСКИХ И ДЕТРИТОВЫХ ЦИРКОНОВ
}

\author{
В.Б. Хубанов, А.А. Цыганков, Г.Н. Бурмакина \\ Геологический институт СО РАН, г. Улан-Удэ, khubanov@mail.ru
}

В статье приведены результаты U-Pb (LA-ICP-MS) датирования детритовых цирконов из аллювиальных отложений р. Ангаракан (Северо-Муйский хребет, Северное Прибайкалье), водосборный бассейн которой сложен в основном гранитоидами баргузинского комплекса, типоморфного для позднепалеозойского Ангаро-Витимского батолита. В изученной популяции обломочных цирконов установлено три возрастных кластера с пиками 728, 423 и 314 млн. лет. Показано, что источником неопротерозойских и раннепалеозойских цирконов являются небольшие останцы магматических и метаморфических пород, вероятно подобные крупным провесам кровли АВБ, закартированным за пределами водосборного бассейна. Позднепалеозойский кластер включает два сближенных пика с возрастом 314 и 285 млн. лет, которые полностью «перекрываются» с временем формирования АВБ и указывают на гранитоидный источник цирконов. Данные детритовой геохронологии, в совокупности с данными по коренным источникам, указывают на длительное, около 40 млн. лет, формирование Ангаро-Витимского батолита, однако вопрос об интенсивности магматизма в течение этого времени требует дополнительных исследований. На основе анализа опубликованных геологических, геохимических и геохронологических данных предполагается, что формирование АнгароВитимского батолита происходило в результате плюм-литосферного взаимодействия, начавшегося в обстановке тектонического сжатия и сменившегося на рубеже 305 - 300 млн. лет (граница карбона и перми) растяжением, обусловившим смену «коровых» гранитоидов, гранитоидами, образованными за счет смешанного мантийно-корового источника.

Ключевые слова: U-Pb геохронология, LA-ICP-MS, детритовый циркон, современный аллювий, Ангаро-Витимский гранитоидный батолит, SLIP, Северное Прибайкалье.

\section{ВВЕДЕНИЕ}

Значительная часть Западного Забайкалья сложена различными гранитоидами, которые, в своем большинстве, составляют ареал-плутон под названием АнгароВитимский батолит (АВБ) [Салоп, 1967; Литвиновский и др., 1993]. Батолит включает в себя сотни, а может быть, тысячи пространственно сближенных отдельных гранитоидных тел, в совокупности занимающих площадь более 200 тыс. км². Типоморфными породами АВБ являются известково-щелочные граниты баргузинского комплекса, которые составляют около двух третей батолита [Litvinovsky et al., 2011]. По масштабам проявления гранитоидного магматизма АВБ сопоставим с известными салическими 
(кремнекислыми) крупными изверженными провинциями мира (Silicic Large Igneous Province, SLIP) [Bryan, 2007].

За последние два десятилетия для гранитоидов АВБ получено значительное количество изотопных датировок, свидетельствующих об их позднепалеозойском возрасте [Ярмолюк и др., 1997а; Цыганков и др., 2007; 2010; 2017; Ковач и др., 2012; Хубанов и др., 2016; и др.]. Результатом этих исследований стало осознание того, что формирование АВБ никак не связано с каледонскими тектоническими событиями. Это, в свою очередь, выдвинуло на первый план проблему геодинамики столь масштабного гранитообразования (см. обзор в Цыганков и др., 2017). Предложено несколько моделей формирования АВБ: плюмовая [Ярмолюк и др., 1997а; Ярмолюк и др., 1997б; 2013; Yarmolyuk et al., 2014], модель активной континентальной окраины [Рыцк и др., 1998; Zorin, 1999; Donskaya et al., 2013], анатектическое плавление коры при ее утолщении в условиях внутриконтинентального сжатия и радиогенного разогрева [Шацило и др., 2014], постколлизионная модель [Цыганков и др., 2010; Litvinovsky et al., 2011] и модель деламинации коры коллизионного орогена [Гордиенко и др., 2003; Киселев и др., 2004]. В некоторой степени разнообразие взглядов обусловлено тем, что, не смотря на значительный прогресс в геохронологическом изучении магматизма Забайкалья в целом, по-прежнему нет полной ясности в понимании общей продолжительности и хронологии формирования разнотипных гранитоидов АВБ; в соотношении времени завершения герцинских тектонических событий [Руженцев и др., 2012] и начала массового гранитообразования; в этапах щелочно-основного и щелочно-гранитоидного магматизма региона и т.д.

Главные трудности в оценке хронологии процессов формирования АВБ связаны с невозможностью датирования каждого из многих сотен его плутонов, а также ввиду сложности интерпретации изотопно-геохронологических данных в случае вероятного нарушения изотопной системы. Поэтому в настоящей работе для расшифровки истории становления известково-щелочных гранитов АВБ использован подход, представляющий собой совокупный анализ U-Pb изотопных возрастов детритовых (обломочных) цирконов из осадков современных водотоков, дренирующих преимущественно выходы гранитов баргузинского комплекса, типоморфного для АВБ, и магматических цирконов из собственно этих гранитов. Определение $\mathrm{U}-\mathrm{Pb}$ изотопного возраста цирконов осуществлялось с помощью метода масс-спектрометрии с индуктивно-связанной плазмой и лазерным пробоотбором (Laser Ablation Inductively Coupled Plasma Mass Spectrometry, LA-ICP-MS). При этом ожидается, что возрастные данные, полученные при датировании тех и других цирконов, будут сопоставимы между собой, что будет служить некоторым критерием достоверности оценки длительности и возможной стадийности становления баргузинского комплекса, гранитоиды которого обнажены на водосборной площади. Кроме того, в свете новых геохронологических данных для известково-щелочных гранитоидов, обсуждаются продолжительность, последовательность и некоторые геодинамические аспекты масштабного и разнотипного позднепалеозойского гранитообразования Западного Забайкалья.

\section{КРАТКИЙ ГЕОЛОГИЧЕСКИЙ ОЧЕРК}

В Западном Забайкалье выходы гранитоидов Ангаро-Витимского батолита занимают площадь порядка 200 тыс. км², а общий ареал их распространения превышает 
500 тыс. км² (рис. 1) [Салоп, 1967; Литвиновский и др., 1993; Litvinovsky et al., 2011]. Объем магматического материала (гранитоидов), слагающего батолит, составляет, по разным оценкам, от 0.7 до 1.5 млн км³ [Турутанов, 2007; Цыганков и др., 2017]. Позднепалеозойский магматизм Забайкалья развивался на гетерогенном фундаменте, представляющем собой коллаж разновозрастных террейнов различной геодинамической природы: архей-палеопротерозойские кратонные, рифей-раннепалеозойские океанические, флишевые, островодужные, метаморфические террейны и террейны пассивной окраины (врезка, рис. 1) [Зоненштайн и др., 1990; Булгатов, Гордиенко, 1999].

В составе АВБ выделяют несколько интрузивных комплексов (серий) [Цыганков и др., 2010; 2017; Litvinovsky et al., 2011], различающихся составом и формировавшихся в определенной последовательности, но со значительным, а в ряде случаев полным перекрытием во времени. Наиболее ранними являются высококалиевые известковощелочные (рис.1) автохтонные и аллохтонные граниты баргузинского комплекса. Они составляют основной объем АВБ и образуют ареал со сложными очертаниями и площадью около 120-150 тыс. км². Следует отметить, что автохтонные граниты нередко содержат многочисленные недоплавленные фрагменты протолита (разнообразных метаморфитов), или сопровождаются зонами мигматизации, образующими «постепенный» переход к вмещающим кристаллическим сланцам. Для автохтонных гранитоидов (порядка 20 \% объема баргузинского комплекса) характерна одинаковая ориентировка гнейсовидности гранитов, директивных текстур крупных скиалитов и вмещающих метаморфических образований [Рейф, 1976; Литвиновский, Занвилевич, 1976; Литвиновский и др. 1993]. Преобладающие аллохтонные фациальные разновидности баргузинских гранитов содержат ксенолиты вмещающих пород и сопровождаются ореолами термального метаморфизма [Рейф, 1976].

Опубликованные к настоящему времени изотопно-геохронологические данные [см. обзор в Ярмолюк и др., 1997а; Цыганков и др., 2007; 2010; 2017; Ковач и др., 2012; Шацило и др., 2015; Хубанов и др., 2016 и др.] не оставляют сомнений в позднепалеозойском возрасте баргузинских гранитов, однако длительность их формирования, равно как и АВБ в целом, оценивается по-разному. По одним представлениям [Ковач и др., 2012; Ярмолюк и др., 2013] становление баргузинского комплекса произошло в течение примерно 20 млн лет в интервале 300 - 280 млн лет назад. Согласно другим данным [Цыганков и др., 2007; 2010; 2017; Хубанов и др., 2016; Litvinovsky et al., 2011] этот интервал составлял около 50 млн лет - 330-280 млн лет назад.

Вслед за баргузинскими гранитами, но со значительным временным перекрытием (305 - 285 млн лет назад), одновременно формировались высококалиевые известковощелочные кварцевые монцониты, кварцевые сиениты и габброиды чивыркуйского комплекса и переходные от известково-щелочных к субщелочным лейкограниты и кварцевые сиениты зазинского комплекса [Цыганков и др., 2010; Litvinovsky et al., 2011]. Те и другие сопровождаются минглинг-дайками, синплутоническими базитовыми интрузиями и содержат мафические микрогранулярные включения [Литвиновский и др., 1995а; 1995б; Титов и др., 1998; 2000; Бурмакина, Цыганков, 2013; Цыганков и др., 2016; Бурмакина и др., 2018; Litvinovsky et al., 2011; 2012; 2017], свидетельствующие о синхронности мафического и гранитоидного магматизма в этот период времени.

В южной половине Западно-Забайкальской провинции гранитоиды АВБ прорываются позднепалеозойской шошонитовой сиенит-монцонитовой с подчиненными 
базитами интрузивной серией, выделяемой в качестве нижне-селенгинского комплекса [Цыганков и др., 2010; Litvinovsky et al., 2011], а также многочисленными щелочногранитоидными плутонами позднепалеозойского раннекуналейского (285-275 млн лет назад) и мезозойского позднекуналейского (230-200 млн лет) комплексов, входящих в состав Северо-Монголо-Забайкальского вулканоплутонического пояса (СМЗП) [Занвилевич и др., 1985; Гордиенко, 1987; Воронцов, Ярмолюк, 2004; Reichow et al., 2010; Цыганков и др., 2019]. Кроме того, в позднем палеозое в пределах площади, занятой АВБ произошло становление ряда щелочных массивов (йолитов, щелочных габбро, лейцитовых и нефелиновых сиенитов) сайженского [Doroshkevich et al., 2012; Дорошкевич и др., 2018; Избродин и др., 2017] и сыннырского [Покровский, Жидков, 1993] комплексов, маркирующих одноименные рифтовые зоны [Ярмолюк и др., 2013] в северо-западной и центральной частях АВБ.

Еще раз подчеркнем, что постбаргузинские гранитоидные комплексы содержат синхронные базиты в той или иной форме проявления (см. выше), тогда как базитов, ассоциирующих с баргузинскими гранитами, пока не установлено.

\section{МЕТОДИКА ИССЛЕДОВАНИЙ}

Подготовка цирконов. Выделение цирконов из гранитоидов представляло собой процедуру дробления, просеивания и отбора фракции менее 250 мкм, сепарации по плотности с помощью тяжелой жидкости (бромоформ) и магнитным свойствам. Обломочные цирконы выделялись из шлиха, намытого из речного среднезернистого аркозового песка, посредством сепарации по плотности и магнитным свойствам. Затем из тяжелой фракции зерна цирконов отбирались вручную под бинокулярным микроскопом, ополаскивались 3\% раствором азотной кислоты в ультразвуковой ванне. Цирконы фиксировались в эпоксидной смоле, после чего подверглись шлифованию до выведения зерен на поверхность и полировке. Готовый препарат представлял собой цилиндр с диаметром 25 мм и высотой не более 8 мм. Для стандартных цирконов был приготовлен отдельный препарат, также цилиндрической формы, диаметром 10 мм и высотой менее 8 MM.

Оборудование и параметры настроек. U-Pb изотопное LA-ICP-MS датирование цирконов проводилось с помощью высокоразрешающего магнитно-секторного массспектрометра с индуктивно-связанной плазмой Element XR (Thermo) и лазерной приставки для пробоотбора UP-213 (NewWave) в Центре коллективного пользования «Аналитический центр минералого-геохимических и изотопных исследований» ГИН СО РАН (г. Улан-Удэ). Операционные параметры и конфигурация оборудования для анализа в большинстве своем были идентичны тем, что приведены в [Хубанов и др., 2016; Буянтуев и др., 2017] (табл. 1). Масс-спектрометром измерялись сигналы следующих изотопов: ${ }^{202} \mathrm{Hg},{ }^{204}(\mathrm{Hg}+\mathrm{Pb}),{ }^{206} \mathrm{~Pb},{ }^{207} \mathrm{~Pb},{ }^{208} \mathrm{~Pb},{ }^{232} \mathrm{Th},{ }^{238} \mathrm{U}$ (табл. 1). Сигнал ${ }^{235} \mathrm{U}$ рассчитывался из сигнала ${ }^{238} \mathrm{U}$, основываясь на постоянстве современного значения их отношения $\left({ }^{238} \mathrm{U} /{ }^{235} \mathrm{U}\right.$ = 137.88). Съемка проводилась в скоростном режиме электростатического сканирования (E-scan). Диапазон беспрерывного E-scan сканирования масс (от 202 до 238 а.е.м.) позволял производить измерения сигналов изотопов без переключения магнитного поля. Детектирование сигналов проводилось в режиме счета «Counting», кроме изотопов ${ }^{232} \mathrm{Th}$ и ${ }^{238} \mathrm{U}$ - в режиме «Analog». 
Процедура измерения и расчета. В качестве внешнего стандарта измерялись эталонные цирконы 91500 (возраст 1065 млн лет) [Wiedenbeck et al., 1995], в качестве контрольного образца - эталоны Plešovice (337 млн лет) [Slama et al., 2008] и GJ-1 [Jackson et al., 2004]. Относительные погрешности измерения изотопных отношений ${ }^{208} \mathrm{~Pb} /{ }^{232} \mathrm{Th}$, ${ }^{207} \mathrm{~Pb} /{ }^{206} \mathrm{~Pb},{ }^{206} \mathrm{~Pb} /{ }^{238} \mathrm{U}$ и ${ }^{207} \mathrm{~Pb} /{ }^{235} \mathrm{U}$ в контрольных образцах варьировали в пределах от 1 до 3\%. Значения относительной погрешности средневзвешенных конкордантных возрастов цирконов Plešovice и GJ-1, определенных LA -ICP-MS методом, составляли менее 2\% от их аттестованного значения возраста. Обработка данных анализа выполнена в программах Glitter [Griffin et al., 2008] и Microsoft Excel с надстройкой Isoplot [Ludwig, 2008]. C помощью последней программы проводились: ${ }^{207} \mathrm{~Pb}$-коррекция на присутствие в ${ }^{206} \mathrm{~Pb} /{ }^{238} \mathrm{U}$ изотопной системе обыкновенного свинца, при этом, изотопные отношения общего свинца определялись с помощью двухстадийной модели эволюции свинца по [Stacey, Kramers, 1975]; рассчитывались значения средневзвешенных возрастов и строились графики распределения изотопных отношений с U-Pb конкордией; а также гистограммы и кривые плотности вероятности распределения возрастов детритовых цирконов. Кроме того, с использованием макроса AGE PICK (Gehrels, Arizona LaserChron Center) были рассчитаны возрастные пики для детритовых цирконов. Гистограммы и кривые относительной вероятности для цирконов древнее 1 млрд лет построены по ${ }^{207} \mathrm{~Pb} /{ }^{206} \mathrm{~Pb}$ значениям возраста с ошибкой $2 \sigma$, для цирконов моложе 1 млрд лет - по возрасту, рассчитанному по ${ }^{206} \mathrm{~Pb} /{ }^{238} \mathrm{U}$ с ошибкой $2 \sigma$.

Стратегия датирования. Для соблюдения условий случайной выборки измерение изотопных отношений в цирконах проводилось без какого-либо их предварительного отбора по размеру или морфологии. Для каждой пробы магматических цирконов датировалось не менее пятнадцати зерен, по одной точке абляции на зерно. При этом диаметр испаряющего лазерного луча составлял 25 мкм, а размеры зерен, как правило, не превышали 100 мкм по длинной оси. По нашему мнению, при подобных размерах лазерного луча и зерен, несколько десятков измерений на пробу позволило выделить статистически значимые значения возрастов даже при отсутствии данных о внутренней структуре цирконов.

При проведении измерений магматических цирконов выстраивалась следующая аналитическая последовательность: в начале и в конце - по два измерения эталонного циркона, используемого в качестве внешнего стандарта (91500), и по одному измерению двух контрольных эталонов (Plešovice и GJ-1), далее через каждые пять измерений неизвестных цирконов проводилось по одному измерению всех трех эталонов.

Проба обломочных цикронов взята из осадков, для которых источником материала, согласно геологической карте (1:200 тыс.), служили окружающие известково-щелочные граниты баргузинского комплекса. Таким образом, возраст обломочных и магматическихцирконов должен совпадать, отражая историю формирования материнских гранитов. Нужно сказать, что такой подход не является оригинальным. Подобный способ сбора цирконов шлиховым методом из одного магматического тела и их U-Pb LA-ICP-MS исследования, например, использовался для датирования экструзивных пород кальдеры Уксичан в Срединном хребте Камчатки [Костицин, Аносова, 2013].

В пробе обломочных цирконов также без какой-либо селекции было исследовано 150 зерен, анализ проводился в одной точке на каждое зерно. Здесь была соблюдена следующая аналитическая последовательность: в начале и в конце - по четыре измерения 
эталонного циркона, используемого в качестве внешнего стандарта (91500) и по одному измерению двух контрольных эталонов (Plešovice и GJ-1), далее через каждые пять анализов обломочных цирконов измерялся стандарт 91500, а через каждые десять Plešovice и GJ-1.

В интерпретации U-Pb изотопных хронологических данных по магматическим и обломочным цирконам учитывались только значения, для которых дискордантность не превышала $10 \%$.

\section{ОБЪЕКТ ИССЛЕДОВАНИЙ}

Одной из территорий, сложенной преимущественно известково-щелочными гранитами баргузинского комплекса, является бассейн р. Ангаракан, дренирующей северозападные склоны центральной части Северо-Муйского хребта (север Западного Забайкалья), в районе пересечения его трассой Байкало-Амурской железнодорожной магистрали (рис. 1). Район более чем на 95 \% (без учета четвертичных отложений) сложен гранитоидами АВБ, среди которых встречаются разновеликие останцы (провесы кровли) докембрийских(?) кристаллических сланцев площадью до нескольких квадратных километров (рис. 2).

Рис. 2 Опробование коренных выходов известково-щелочных гранитоидов баргузинского комплекса АВБ проводилась вдоль бортов верхнего течения р. Ангаракан и его левого притока р. Итыкит. Опробованы средне- крупнозернистые, массивные, порфировидные (кпш) амфиболовые и амфибол-биотитовые граниты, граносиениты и лейкограниты близкого химического состава (см. ниже), представляющие, по-видимому, фациальные разновидности или фазы внедрения единого крупного плутона. Всего отобрано 8 геохронологических проб, химический состав которых приведен в таблице 2. На классификационных петрохимических диаграммах (рис. За, б) они показаны в сравнении с баргузинскими гранитами центральной и юго-западной частей АВБ. Исследуемые гранитоиды содержат 65 - 74 мас. \% $\mathrm{SiO}_{2}$ при 8.5 - 9.4 мас. \% суммы щелочей, что согласно последней версии TAS-диаграммы [Шарпенок и др., 2013] соответствует граносиенитам, умеренно щелочным гранитам и лейкогранитам. Индекс насыщения глиноземом A/CNK варьирует от 0.9 до 1.12, но в большинстве проб - больше 1; агпаитовый индекс NK/A составляет 0.75 - 0.8 (рис. 3б), что в совокупности с повышенным содержанием оксида калия (3.9 - 4.8 мас. \% $\mathrm{K}_{2} \mathrm{O}$ ) определяет их принадлежность к высококалиевой известково-щелочной серии (рис. За), типичной для баргузинского комплекса в целом [Litvinovsky et al., 2011; Цыганков, 2014]. Следует отметить, что биотитовые лейкограниты в целом не характерны для баргузинского комплекса. Они типоморфны для зазинского комплекса, к которому принадлежат крупные плутоны лейкогранитов, площадью в сотни и даже тысячи км² (Цыганков и др., 2010; Litvinovsky et al., 2011), а также жильные и дайковые тела, секущие гранитоиды баргузинского и чивыркуйского комплексов (Цыганков и др., 2007, 2017).

\section{РЕЗУЛЬТАТЫ ДАТИРОВАНИЯ}

Результаты U-Pb изотопного датирования цирконов из гранитоидов верховьев $\mathrm{p}$. Ангаракан и ее притока р. Итыкит приведены в таблице 3 и показаны на рисунках 4 - 7. Средневзвешенные конкордантные возрасты для 4 проб из гранитов (KM-02-15, KM-04-15 KM-07-15, KM-10-15) укладываются в сравнительно узкий диапазон - 310 - 304 млн лет 
(рис. 4): среднезернистый биотитовый гранит КM-02-15 имеет средневзвешенный конкордатный возраст по 19 определениям $304 \pm 3$ млн лет (рис. 4а); среднезернистый амфиболовый гранит КМ-04-15 - 310 \pm 2 млн лет, по 24 цирконам (рис. 4б); среднезернистый биотитовый гранит КМ-07-15 - $307 \pm 2$ млн лет, по 27 точкам (рис. 4в); порфировидный крупнозернистый гранит КM-10-15 - $305 \pm 2$ млн лет, по 16 определениям (рис. 4г). Также на этих рисунках с правой стороны приведены средневзвешенные значения ${ }^{206} \mathrm{~Pb} /{ }^{238} \mathrm{U}$ возраста с ${ }^{207} \mathrm{~Pb}$-коррекцией на нерадиогенный свинец. Корректированные данные дают возраст аналогичный конкордатному, при этом имеют несколько меньшее среднеквадратичное отклонение (СКВО). В целом полученные оценки возраста для этих проб в пределах погрешности сопоставимы друг с другом.

В четырех других пробах (KM-01-15, KM-06-15, KM-05-15, KM-09-15) наблюдается значительный разброс значений возрастов цирконов. В пробе порфировидного среднезернистого амфибол-биотитового граносиенита КМ-01-15 (рис. 5а) отмечено три возраста: основное количество цирконов, 28 зерен, показали средневзвешенный конкордатный возраст $303 \pm 3$ млн лет, одно зерно - $472 \pm 15$ млн лет и еще одно зерно $772 \pm 9$ млн лет. В пробе порфировидного среднезернистого амфиболового граносиенита КМ-06-15 (рис. 5б) обнаружено два возрастных кластера: 16 определений соответствуют конкордантному возрасту $305 \pm 3$ млн лет и для двух цирконов установлен средневзвешенный конкордантный возраст $444 \pm 24$ млн лет. В пробе массивного среднезернистого лейкогранита КM-05-15 (рис. 6а) конкордантные определения дают вариации от 280 до 320 млн лет, при этом на гистограмме плотностной вероятности распределения ${ }^{206} \mathrm{~Pb} /{ }^{238} \mathrm{U}$ возрастов (правый график) наблюдаются максимальный пик из 14 определений на уровне 280 млн лет, менее выраженный из 6 определений - на 306 млн лет и еще меньший из 4 определений - на 314 млн лет. Наиболее широкий разброс дат обнаруживается в пробе мелкозернистого амфибол-биотитового лейкогранита KM-09-15 от 293 до 884 млн лет (рис. 6б). На гистограмме плотностной вероятности распределения ${ }^{206} \mathrm{~Pb} /{ }^{238} \mathrm{U}$ возрастов относительно слабо выражены пики на 320 млн лет и 708 млн лет.

Детритовые цирконы были выделены из серого шлиха, намытого из речного среднезернистого аркозового песка, отложенного 500 м ниже по течению от места слияния p. Ангаракан и р. Итыкит. Площадь водосбора верховьев р. Ангаракан и р. Итыкит составляет около $350 \mathrm{kм}^{2}$ и сложена, согласно геологической карте, исключительно аллохтонными гранитоидами, краткая характеристика которых приведена выше. Однако следует отметить, что за пределами водосборной площади верховьев р. Ангаракан и р. Итыкит среди обширных полей гранитоидов закартированы останцы метаморфических сланцев, относимых, согласно легенды геологической карты масштаба 1:200000 (Лист О49-XXXVI), к муйской серии нижнего протерозоя. Из пробы SHL-01-15 из аркозового песка среднего течения р. Ангаракан проанализировано 150 цирконов, из них для хронологических оценок отобрано 140 зерен с D (коэффициент, характеризующий степень дискордантности) $<10 \%$. Чуть более 44 \% проанализированных цирконов (60 зерен) имеют позднепалеозойский возраст (рис. 7a), 29 цирконов (21\%) характеризуются раннесреднепалеозойским возрастом с пиком 423 млн лет. Значительное количество цирконов (около 26 \%) имеют неопротерозойский возраст с максимумом 782 млн лет; в единичных зернах зафиксированы даты 1100, 1400, 1760, 1825 млн лет. Цирконов моложе 248 млн лет не обнаружено. 
Более детальный анализ позднепалеозойского временного интервала, на который приходится почти половина всех цирконов, показывает, что здесь статистически значимо выделяются два максимума (рис. 7б) с возрастом 314 и 285 млн лет (30 и 21 зерно, соответственно).

\section{ОБСУЖДЕНИЕ}

\section{Геохронология: стадийность и продолжительность позднепалеозойского гранитоидного магматизма.}

В основе настоящего исследования лежит вполне очевидное предположение о том, что изотопный $\mathrm{U}-\mathrm{Pb}$ возраст цирконов из аллювиальных отложений современных водотоков соответствует возрасту коренных источников водосборного бассейна. В качестве тестовой территории нами выбран водосборный бассейн р. Ангаракан, стекающей с западных склонов Северо-Муйского хребта (Северное Прибайкалье) в районе его пересечения трассой Байкало-Амурской железнодорожной магистрали. Водосборный бассейн и прилегающие территории характеризуются расчлененным среднегорным рельефом и хорошей обнаженностью (гольцовая зона). Водосборная площадь сложена крупно-среднезернистыми массивными и порфировидными (Kfs) биотитовыми гранитами и граносиенитами (см. рис. 2), аналогичными гранитоидам баргузинского комплекса центральной и юго-западной части Ангаро-Витимского батолита. Эти гранитоиды прорваны небольшими телами сложной конфигурации, штоками и дайками мелкосреднезернистых лейкогранитов (см. рис. 2), которые могут быть параллелизованы с гранитами зазинского коплекса центральных и южных районов АВБ.

B пробе SHL-01-15, отобранной из русловых песчаных отложений р. Ангаракан, проанализировано 140 зерен циркона, которые на графике распределения плотности вероятности возрастов образуют три четко обособленных кластера с максимумами 782, 423 и 314 млн. лет (рис. 7а). Природа неопротерозойского и раннепалеозойского (силур, граница венлок - лудлов) кластеров может быть различна. Эти цирконы могут быть извлечены из самих гранитоидов баргузинского комплекса, что согласуется с отдельными определениями древних цирконов в магматических пробах, где они присутствуют в качестве ксенозерен и/или древних ядер в сложнозональных зернах циркона. Вместе с тем раннепалеозойских и неопротерозойских цирконов в пробах гранитоидов несопоставимо меньше, чем среди обломочных цирконов. Это означает, что в пределах водосборной площади могут иметься самостоятельные источники древних цирконов, что согласуется с наличием останцев метаморфических пород, и вероятно, раннепалеозойских гранитов, среди гранитоидов баргузинского комплекса. Следует отметить, что в пределах БайкалоМуйского пояса, в том числе Северо-Муйского хребта, широко распространены раннепалеозойские и неопротерозойские магматические и метаморфические комплексы [Рыцк и др., 1998; 2001; 2009; 2018], связанные с байкальской аккрецией и каледонским тектоногенезом. Кроме того, раннепалеозойские и неопротерозойские максимумы на кривой плотности вероятности коррелируют с хронологией глобальных, по крайней мере, в масштабах южного складчатого обрамления Сибирского кратона, корообразующих процессов [Цыганков и др., 2018].

Наибольший интерес, в контексте данной работы, представляет позднепалеозойский кластер с пиком 314 млн. лет. При более детальном рассмотрении видно, что этот кластер включает два пика с возрастом 314 и 285 млн. лет (рис. 7б), 
которые коррелируют как с возрастом гранитоидов Ангаро-Витимского батолита в целом (рис. 8) [Ярмолюк и др., 1997а; Цыганков и др., 2007; 2010; 2016; 2017; Ковач и др., 2012; Шацило и др., 2014; Хубанов и др., 2016], так и с возрастом гранитов, отобранных непосредственно в пределах водосборного бассейна. При этом, детритовые цирконы ожидаемо дают больший размах возрастов, по сравнению с коренными источниками [Condie et al., 2009].

Таким образом, полученные данные не оставляет сомнений в том, что позднепалеозойский кластер на графике распределения плотности вероятности возрастов обусловлен цирконом из гранитоидов АВБ. В то же время, детальное сопоставление данных детритовой и коренной геохронологии показывает, что картина распределения возрастов значительно сложнее, чем предполагалось в начале. Во-первых, имеет место некоторый «сдвиг» пиков возрастов магматических цирконов (пик 280 по 14 измерениям и 306 млн лет по 123 измерениям) и обломочных цирконов (пик 285 по 21 измерению и 314 по 30 измерениям) относительно друг друга на 5 и 8 млн лет (рис. 7б и 7г). Во-вторых, среди гранитов не обнаружено разновидностей с возрастом более 310 млн лет и, наконец, не ясна природа бимодальности в распределении позднепалеозойских возрастов обломочных цирконов. В конечном счете, вопрос заключается в том, какие данные «обломочные» или «коренные», более объективны для решения вопроса об общей длительности и возможной стадийности позднепалеозойского гранитоидного магматизма Забайкалья?

Безусловным достоинством детритовой геохронологии является площадной характер «опробования», при котором количество разновозрастных цирконов в осадочных отложениях в первом приближении пропорционально площади обнаженной поверхности пород разного возраста. Трудность же заключается в невозможности точной «привязки» обломочных цирконов к какому-либо литологическому (петрографическому) типу пород. Достоинства и недостатки «коренной» геохронологии прямо противоположны: известно, что датировано, но какой объем геологического пространства характеризует полученная дата, особенно при отсутствии детальных геологических карт, не всегда можно определить с достаточной точностью. Более того, как выяснилось в последние годы (Цыганков и др., 2010; Litvinovsky et al., 2011 и ссылки в этих работах), петрографически однотипные магматические породы, например, гранитоиды, развитые в пределах достаточно большой площади, могут иметь разный изотопный возраст, также как субсинхронными могут быть петрографически разнотипные образования.

Большинство определений возраста магматических цирконов из гранитоидов рассматриваемого района укладывается в диапазоне от 310 до 302 млн лет, перекрывая друг друга с учетом погрешности метода (табл. 3). От этих значений заметно отличается проба КM-05-15 (280 млн. лет). Выше отмечалось, что лейкограниты (проба КM-05-15) типоморфны для зазинского комплекса, тогда как в составе баргузинского они редки. Макро- и микроэлементный состав баргузинских и зазинских гранитов в значительной степени перекрываются (Цыганков и др., 2017). Однако, учитывая повышенное содержание $\mathrm{SiO}_{2}$ в граните KM-05-15 (табл. 2), его лейкократовый облик и наличие небольших пегматоидных обособлений, характерных для зазинских гранитов, есть основания для отнесения данной пробы именно к зазинскому комплексу. Не смотря на значительное перекрытие датировок баргузинских и зазинских гранитов (рис. 8 и ссылки в подписи к нему), геологические соотношения указывают на более позднее формирование 
зазинских гранитов, что было зафиксировано, например, в бассейне р. Курбы (Цыганков и др., 2007), на восточном побережье оз. Байкал (Цыганков и др., 2017), в некоторых других районах. В рассматриваемом районе доминирующие граниты и граносиениты баргузинского типа также прорваны лейкократовыми гранитами зазинского типа (см. рис. 2). Таким образом, есть все основания считать, что проба КМ-05-15 характеризует возраст зазинских гранитов бассейна р. Ангаракан. Соответственно пик 280 млн. лет на рис. 7 г, обусловлен именно этой пробой (см. также рис. 6а).

Остальные пробы варьирующих по составу граносиенитов и гранитов баргузинского типа со средним возрастом 306 млн. лет (от 310 до 302 млн лет), отобранные на сравнительно небольшом по площади участке, характеризуют по-видимому фациальные разновидности единого крупного плутона. Его усредненный возраст - 306 млн. лет, с одной стороны, согласуется с возрастом баргузинских гранитов из других районов их распространения (рис. 8), а с другой, не исключает присутствия останцев несколько более ранних гранитоидов с интегральным возрастом около 314 млн. лет. Принципиальная возможность такой интерпретации, т.е. наличия в пределах водосборного бассейна гранитоидов с возрастом более 310 млн. лет, поддерживается следующими соображениями. Пик 314 млн лет образуют 30 зерен обломочных цирконов, что составляет примерно пятую часть (21.5 \%) (табл. 3) от всей выборки датированных детритовых цирконов. Это статистически значимая величина, которая позволяет исключить случайные факторы. В том числе, это не может быть «смешанным» возрастом (захват разновозрастных зон циркона), не имеющим геологического смысла, поскольку: а) все значения лежат в сравнительно узком диапазоне, что трудно ожидать в случае возрастной гетерогенности анализируемой области (25 микрон в поперечнике), иначе говоря случайные значения не дают статистически значимых пиков; б) возрастной пик 314 млн лет коррелирует с возрастом баргузинских гранитов центральной части батолита [Цыганков и др., 2017], тогда как не имеющие геологического смысла определения (смешанные) вряд ли будут коррелировать с какими-либо известными геологическим событиями; в) различного рода процессы (термальные, метасоматические), нарушающие изотопное равновесие, как правило приводят к омоложению изотопного возраста и характеризуются дискордантностью, превышающей принятый нами 10 \% уровень; г) имеются четко выраженные кластеры 423 и 782 млн лет, которые коррелируют с каледонскими и неопротерозойскими эндогенными событиями в регионе, но не отражены на использованной геологической карте (м-б 1:200000) данного участка (см. рис. 2). Кроме того, в рассматриваемом районе широко распространены гнейсовидные граниты (рис. 2), возможные аналоги которых имеют возраст 325 и 316 млн. лет [Цыганков и др., 2007, 2012].

Таким образом, основной вывод заключается в том, что данные «площадного опробования», отраженные в возрасте детритовых цирконов, точнее характеризуют длительность и стадийность магматизма, по сравнению с «точечной» геохронологией коренных пород.

Если этот вывод верен, то это означает, что пики 285 и 314 млн. лет реально отражают непрерывно-пульсационный характер магматизма. Учитывая ранее опубликованные данные (рис. 8а) можно предположить, что в пик 314 млн. лет основной вклад вносят граниты баргузинского типа, тогда как популяция цирконов с интегральным возрастом 285 млн. лет, образована преимущественно гранитоидами зазинского типа. 
Косвенно это подтверждается меньшим на 1/3 количеством цирконов поздней популяции, что согласуется с подчиненным распространением этих гранитов в рассматриваемом районе.

Можно предположить, что выявленная закономерность присуща позднепалеозойскому магматизму Забайкалья в целом, поскольку аналогичные максимумы - 315 и 285 млн. лет, зафиксированы в обломочных цирконах Селенги, Витима и Муи [Цыганков и др., 2020]. Кроме того, ${ }^{40} \mathrm{Ar} /{ }^{39} \mathrm{Ar}$ изотопные данные о возрасте ряда золоторудных объектов Забайкалья, в том числе в пределах Байкало-Муйской складчатой области, указывают на пространственно-временную связь процессов концентрирования золота в рудных телах и образования гранитоидов АВБ [Ivanov et al., 2015; Чугаев и др., 2015; Ванин и др., 2018б]. Для формирования рудной минерализации также выделяется два возрастных рубежа - 330-320 млн лет и 285-265 млн лет [Ванин и др., 2018а]. Вместе с тем, новые и опубликованные данные коренной геохронологии (рис. 8а) не подтверждают этого предположения. Представленная на рис. 8 гистограмма распределения U-Pb изотопных «возрастов» заимствована из [Цыганков и др., 2017] и дополнена данными, приведенными выше (показаны звездочками). Диаграмма построена по принципу «один массив - одна дата». В соответствие с этим в интервал 310 - 300 млн. лет попадает один массив, по которому получено шесть датировок (см. выше), со средним возрастом 306 млн. лет. Представленная диаграмма демонстрирует одномодальное распределение возрастов с максимумом в диапазоне 300 - 380 млн. лет. Граниты баргузинского комплекса являются наиболее ранними, что следует как из изотопных, так и из геологических данных. При этим главный максимум обломочных цирконов (314 млн. лет) совпадает с ранней стадией формирования батолита (рис. 8а), которая охарактеризована всего четырьмя массивами. «Второстепенный» максимум обломочных цирконов (285 млн. лет) напротив, совпадает с максимумом «коренной летописи», однако баргузинских гранитов в это время уже не формировалось.

Причины расхождения данных коренной и обломочной геохронологии могут быть различны. Возможно, имеет место селективность отбора коренных объектов (массивов) для геохронологического изучения, тогда как данные по обломочным цирконам имеют более случайный характер, хотя и в этом случае возможность некоторой селекции нельзя исключить полностью. Однако с нашей точки зрения проблема имеет вполне логичное объяснение, суть которого в том, что каждая датировка баргузинских гранитов характеризует несопоставимо больший объем геологического пространства, по сравнению с другими комплексами, поскольку на баргузинские граниты приходится не менее 2/3 всего объема (обнаженной поверхности) АВБ [Ярмолюк и др., 1997; Литвиновский и др., 1993; Цыганков и др., 2010; Litvinovsky et al., 2011].

Таким образом можно констатировать, что основной объем Ангаро-Витимского батолита (щелочные граниты не входят в его состав [Цыганков и др., 2010; Litvinovsky et al., 2011]) формировался длительное время, не менее 40 млн. лет (320 до 280 млн. лет назад). Вопрос стадийности его формирования АВБ в целом, равно как и доминирующих баргузинских гранитов, остается открытым.

Принадлежность к SLIPs и геодинамические следствия: обстановка сжатия и плюм-литосферное взаимодействие. По своим площадным (ареал до 0.5 млн км²) и объемным (по разным оценкам 0.7 до 1.5 млн км³) масштабам, продолжительности формирования, ( 40 млн. лет), выдержанности состава типоморфных гранитов 
баргузинского комплекса на большой площади Ангаро-Витимский батолит удовлетворяет условиям принадлежности к салическим (кремнекислым) крупным изверженным провинциям (Silicic Large Igneous Province, SLIP) [Bryan, 2007; Bryan, Ernst, 2008]. Однако, позднепалеозойская Западно-Забайкальская гранитоидная провинция (АВБ) существенно отличается от типичных SLIPs практически полным отсутствием комагматичных кислых вулканитов. По крайней мере на сегодняшний день, не найдены какие-либо свидетельства наличия вулканических аналогов баргузинских гранитов. Можно предположить, что изначально на момент становления АВБ известково-щелочные кислые вулканиты имели очень подчиненное значение и/или впоследствии были полностью эродированы.

Ранее рядом исследователей были приведены убедительные аргументы в пользу того, что позднепалеозойский гранитоидный магматизм Западного Забайкалья развивался на фоне конвергентных геодинамических условий. Об этом говорят: развитие девонкаменоугольных межгорных осадочных бассейнов типа форланд и позднепалеозойских надвиговых структур, индикаторы карбон-пермского регионального метаморфизма и палеомагнитные данные [Руженцев и др., 2005; 2012; Мазукабзов и др., 2010; Шацилло и др., 2014; Резницкий и др., 2015 и др.]. При этом могло иметь место совмещение двух геодинамических событий, которые обеспечили орогенез в регионе - это закрытие Монголо-Охотского океанического бассейна юго-восточнее (в современных координатах) от АВБ [Zorin, 1999; Donskaya et al., 2013; Гордиенко, 2006] и разворот Алданского кратонного блока относительно Ангаро-Оленекского кратонного блока, между которыми была «зажата» северная половина Западного Забайкалья [Powerman et al., 2013; Шацилло и др., 2014]. Последнее событие, по-видимому, связано с раскрытием Вилюйской палеорифтовой системы в результате воздействия мантийного плюма [Масайтис, 2006; Pavlov., 2008; Powerman et al., 2013; Шацилло и др., 2014; Полянский и др., 2018].

Поэтому есть основания считать, что гранитоидные магмы АВБ генерировались из вещества утолщенной континентальной коры в результате ее радиогенного разогрева [Шацилло и др., 2014] и/или декомпрессионного плавления при развале орогена в постколлизионную стадию [Мазукабзов и др., 2010; Цыганков и др., 2010; Litvinovsky et al., 2011]. В обоих случаях на столь огромной площади ожидаемы широкие вариации состава гранитоидных магм и производных их кристаллизации, в частности, гранитоидов баргузинского комплекса. Это должно быть обусловлено гетерогенностью природы и состава протолитов, т.е фундамента (коллаж террейнов) Западного Забайкалья, а также локальностью и мозаичностью радиогенного разогрева и возникновения декомпрессионных условий, что обеспечивает различную степень плавления протолитов. Однако для автохтонных и аллохтонных высококалиевых известково-щелочных пород баргузинского комплекса наблюдаются относительно однородные минералогопетрографические и геохимические (макро- и микроэлементные) характеристики на всей площади их распространения [Литвиновский и др., 1993; Litvinovsky et al., 2011; Цыганков, 2014; Цыганков и др., 2017], что предполагает выдержанность состава их магм по всему ареал-плутону (АВБ).

Данное противоречие может быть устранено, если предположить существование дополнительного глубинного регионального теплового источника, например, горячего мантийного плюма, воздействовавшего на всю площадь утолщенной литосферы Западного Забайкалья. Этот энергический источник необходим, с одной стороны, для обеспечения сравнительно продолжительного постоянства тепловых условий магмогенерации на 
обширной площади ( 0.5 млн. км²) и, с другой стороны, для поддержки подвижности (циркуляции) компонентов, главным образом летучих и щелочей [Литвиновский и др., 1993]. Оба фактора в совокупности обеспечат относительно выдержанные условия генерации и кристаллизации гранитоидных магм на значительной части ареал-плутона. Действительно, имеются вполне весомые и независимые доказательства в пользу того, что масштабность гранитообразования АВБ также обусловлена тепловым воздействием горячего мантийного вещества на континентальную литосферу. Об этом свидетельствуют следующие факты: гранитоидные тела распределены в виде ареал-плутона, а не в виде линейной зоны (пояса); одновременный с гранитоидами щелочной (сайженский, сынырский комплексы) и базитовый (синплутонические интрузии, минглинг-дайки, габбро-монцонитовые плутоны) магматизм (рис. 8 б); наличие геологических, геохимических и изотопных признаков участия мантийного базитового материала в формировании чивыркуйского, зазинского и нижне-селенгинского комплексов АВБ и близко одновозрастных гранитоидах повышенной щелочности Северо-МонголоЗабайкальского вулканоплутонического пояса (СМЗП) [Ярмолюк и др., 1997; 2013; Yarmoluk et al., 2014; Бурмакина, Цыганков, 2013; Цыганков и др., 2016; 2017 и др.].

В свете представленного обзора вполне уместным выглядит ранее высказанное мнение о том, что развитие магматизма АВБ обусловлено сочетанием геодинамических обстановок сжатия и воздействия мантийного плюма на литосферу Западного Забайкалья [Ярмолюк и др., 1997; Цыганков и др., 2016].

Однако, на наш взгляд, в предшествующих обсуждениях без полного объяснения осталось два вопроса - почему баргузинские граниты не содержат признаков участия мантийного вещества и почему только на заключительной стадии позднепалеозойских событий отмечается максимально разнообразный магматизм с широкими вариациями соотношения мантийной и коровой составляющих?

Совокупный анализ геохронологических данных показывает, что в раннюю стадию становления АВБ, 320-310 млн лет назад, имело место образование в основном только баргузинских гранитов, причем в условиях автохтонной и аллохтонной фаций [Цыганков и др., 2007; 2010]. Эти граниты имеют исключительно коровые изотопные характеристики [Litvinovsky et al., 2011; Цыганков, 2014]. Следует обратить внимание на то, что автохтонные разности пермского возраста (поздней стадии) авторам неизвестны. Автохтонные граниты через зоны мигматизации имеют постепенные переходы в интенсивно деформированные метаморфические породы, что указывает на пластичность протолитов и условия тектонического сжатия. Кроме того, их формирование происходило на глубине средней коры [Рейф, 1976; Цыганков и др., 2017]. При этом в рамках плюмовой модели для плавления материала средней коры необходимо поступление мантийных магм на подстилающие уровни, т.е - в нижнюю кору и низы средней коры. Однако в то время нижняя и средняя кора по причине своей пластичности, ввиду сдвиго-надвигового утолщения и разогрева, должна была быть трудно проницаемой для мантийных магм.

В этом случае можно предположить, что вещество нижней коры испытывало растяжение из-за подпорного влияния восходящего потока мантийного вещества (плюма) (рис. 9а). В контакте с горячим плюмом нижнекоровый материал мог плавиться с Рис. 9 образованием гранитоидных расплавов. Дальнейшее сосуществование этих мантийных и коровых производных должно было привести к их химическому смешению (миксинг) и возникновению гибридных магм, например, монцонитоидных. Следует отметить, что 
одним из условий химического смешения является выравнивание температур контрастных расплавов, а именно кислая составляющая должна быть «перегрета» до температуры близкой к температуре мафического расплава [Врублевская и др., 2013], что возможно при относительно длительном их контакте. Эти гибридные магмы могли всплывать в более плотной окружающей среде нижней коры, которая к тому же испытывала пластичновязкие растягивающие деформации. Однако их барьером для дальнейшего продвижения вверх была перекрывающая также пластично-вязкая и частично расплавленная средняя кора, находящаяся в условиях тектонического сжатия.

Поэтому сравнительно горячая, вследствие инкорпорации мантийного вещества через магматическую гибридизацию, нижняя часть литосферы могла служить источником тепла для кондуктивного прогрева, возможно, дополнительным к радиоактивному разогреву вышележащего среднекорового уровня, в котором происходило выплавление высококалиевых известково-щелочных гранитных расплавов.

Нужно отметить, что данный механизм объясняет отсутствие геофизических признаков наличия крупных базитовых (габброидных) тел в подошве АВБ [Suvorov et al., 2002], что предполагается в рамках «чистой» плюмовой модели. Мантийный материал в значительной степени мог быть инкорпорирован в состав моноцонитоидов нижней коры. Так, по оценкам [Цыганков, 2014] средний состав позднепалеозойского монцонита АВБ может быть получен при смешении в пропорции около 30\% габброидной и 70\% гранитной магм. Последующая эволюция этих гибридных магм и/или плавление монцонитоидов могли привести к формированию кварц-сиенитовых и гранитных расплавов с мантийнокоровыми изотопными характеристиками.

Согласно [Цыганков и др., 2017] глубина современного эрозионного среза составляет не более 10-15 км, что соответствует уровню верхней-средней позднепалеозойской утолщенной коры. Поэтому, возможно, из-за относительно неглубокой эрозии, в регионе практически неизвестны позднекарбоновые проявления мафического (базитового и гибридного) магматизма, за исключением единичных габброидных тел [Лыхин и др., 2010]. Также не исключено, что выявить монцонитоиды карбонового возраста не позволяет относительный дефицит геохронологических данных.

В раннепермское время, или даже в самом конце карбона ( 305 - 300 млн. лет назад) произошла смена тектонического и магматического режимов: по-видимому, условия сжатия литосферы перестали доминировать, но Западное Забайкалье продолжало находится под влиянием мантийного плюма (рис. 9б). Изменение характера доминирующих напряжений от сжатия к, возможно, не повсеместному растяжению повлияло на проницаемость коры для глубинных расплавов. При литосферном растяжении мантийные и нижнекоровые гибридные магмы, а также производные их эволюции получили возможность проникать в среднюю и верхнюю кору, вплоть до их излияния на дневную поверхность. Поэтому на современном эрозионном срезе мы наблюдаем разнотипные магматические комплексы (серии) с различной степенью участия в них мантийного вещества, становление которых произошло близко одновременно в пермское время. Помимо баргузинских гранитов, образованных за счет плавления корового материала, широкое распространение получили монцонитоиды чивыркуйского комплекса, а также субщелочные сиениты и лейкограниты зазинского комплекса, которые характеризуются смешанными мантийно-коровыми изотопными метками. Среди пород этих комплексов также отмечены тела габброидов и базитов, нередко с признаками 
сосуществования контрастных магм. Прямым свидетельством возникновения условий растяжения являются рифтогенные структуры, репером которых являются магматиты с явным участием мантийного вещества - это щелочные породы сайженского и сыннырского комплексов [Покровский, Жидков, 1993; Doroshkevich et al., 2012; Дорошкевич и др., 2018; Избродин и др., 2017; Izbrodin et al., 2020], а также щелочные гранитоиды, бимодальные вулканические и субвулканические серии, выделяемые в составе (СМЗП) [Воронцов, Ярмолюк, 2007; Reichow et al., 2010; Litvinovsky et al., 2011; Цыганков, 2014; Цыганков и др., 2019]. Причем бимодальные вулканиты имеют резко подчиненное значение, но относительно широко распространены субвулканические серии, которые объединяют в себя комплексы субпараллельных субвертикальных тел, нередко с соотношением «дайка в дайке» с образованием полудаек и скринов [Шадаев и др., 2005; Буянтуев и др., 2017], что является структурным признаком условий тектонического расширения.

Сочетание обстановок сжатия земной коры и плюм-литосферного взаимодействия позволяет объяснить дефицит и/или отсутствие вулканических комагматов известковощелочных гранитов баргузинского комплекса. На раннем этапе формирования АВБ , когда по-видимому началось выплавление известково-щелочной гранитоидной магмы, в условиях тектонического сжатия верхняя кора Забайкалья была трудно проницаема для подъема из области генерации на среднекоровой глубине и сдерживала излияние на дневную поверхность вязких кислых расплавов. В ранней перми известково-щелочные кислые расплавы, возможно, извергались, но их количество имело уже подчиненное значение, и в последствии производные этих извержений были в большей степени эродированы.

\section{ОСНОВНЫЕ ВЫВОДЫ}

В результате изотопно-геохронологического изучения (U-Pb, LA-ICP-MS) цирконов из аллювиальных отложений р. Ангаракан (Северо-Муйский хребет, Северное Прибайкалье), водосборный бассейн которой сложен преимущественно гранитоидами баргузинского комплекса, доминирующими в составе Ангаро-Витимского батолита, установлены три возрастных кластера с максимумами 782, 423 и 314 млн. лет. Первый из них коррелируют с возрастом неопротерозойских магматических образований, широко распространенных в северной части Байкальской складчатой области, тогда как второй отвечает времени каледонских орогенических событий в регионе. Позднепалеозойский кластер включает два сближенных пика с возрастом 314 и 285 млн. лет, которые полностью «перекрываются» с временем формирования АВБ и указывают на гранитоидный источник цирконов.

Данные по коренным источникам - биотитовым гранитам, граносиенитам и лейкогранитам баргузинского и, вероятно, зазинского комплексов демонстрируют аналогичный диапазон возрастов, однако их максимумы на кривой плотности распределения возрастов «сдвинуты» относительно детритовых возрастов на 5 - 8 млн. лет. Причина сдвига видится в особенностях отбора проб гранитоидов, локализованных на сравнительно небольшой, по сравнению с водосборным бассейном р. Ангаракан, площади.

Данные детритовой геохронологии, в совокупности с новыми и опубликованными ранее определениями, указывают на длительное, около 40 млн. лет, формирование Ангаро- 
Витимского батолита, однако вопрос об интенсивности магматизма в течение этого времени остается открытым.

Геологические, геохимические и геохронологические данные, в том числе гигантские масштабы гранитообразования и выдержанность состава известково-щелочных гранитоидов баргузинского комплекса, типоморфных для АВБ, свидетельствуют о формировании батолита в результате плюм-литосферного взаимодействия.

Предполагается, что на раннем этапе в карбоне это взаимодействие происходило на фоне тектонического сжатия континентальной коры Западного Забайкалья, что препятствовало подъему мантийных и гибридных магм выше нижней коры, но обусловило генерацию больших объемов однотипных кислых магм (гранитоидов баргузинского комплекса) за счет плавления вещества средней коры.

На рубеже карбона и перми (305 - 300 млн. лет назад) тектоническое сжатие сменилось растяжением, нараставшим в течение всего пермского периода. Смена тектонической обстановки обусловила возможность проникновения мантийных и нижнекоровых гибридных магм и их дифференциатов на средне- верхнекоровые уровни литосферы, что выразилось в субсинхронном формировании разнотипных магматических комплексов (серий) с различной степенью участия в них мантийного и корового вещества.

Благодарности. Авторы выражают благодарность академику В.В. Ярмолюку и анонимному рецензенту за конструктивные замечания, способствовавшими улучшению статьи.

$\mathrm{U}-\mathrm{Pb}$ изотопно-геохронологические исследования и определения химического состава пород проведены в ЦКП «Аналитический центр минералого-геохимических и изотопных исследований» ГИН СО РАН, г. Улан-Удэ. Работа выполнена в рамках фундаментальных исследований ГИН СО РАН (базовый проект IX.129.1.2., № гос. рег. AАAА-A16-116122110027-2), при поддержке проекта II.1.39. Комплексной программы фундаментальных научных исследований СО РАН и гранта РФФИ № 20-05-00344 А.

\section{ЛИТЕРАТУРА}

Булгатов А.Н., Гордиенко И.В. Террейны Байкальской горной области и размещение в их пределах месторождений золота // Геология рудных месторождений, 1999, т. 41, № 3, с. $230-240$.

Бурмакина Г.Н., Цыганков А.А. Мафические включения в позднепалеозойских гранитоидах Западного Забайкалья (Бургасский кварцево-сиенитовый массив): состав, петрогенезис // Петрология, 2013, т. 21, № 3, с. 309-334.

Бурмакина Г.Н., Цыганков А.А., Хубанов В.Б. Петрогенезис комбинированных даек в гранитоидах Западного Забайкалья // Геология и Геофизика, 2018, т. 59, № 1, с. 23-48.

Буянтуев М.Д., Хубанов В.Б., Врублевская Т.T. U-Pb LA-ICP-MS датирование цирконов из субвулканитов бимодальной дайковой серии Западного Забайкалья: методика, свидетельства позднепалеозойского растяжения земной коры // Геодинамика и тектонофизика, 2017, т. 8, № 2, с. 369-384.

Ванин В.А., Иванов А.В., Татаринов А.В., Горовой В.А. Возраст и этапы формирования золоторудных месторождений Байкало-Муйского пояса и Удино-Витимской зоны (Центрально-Азиатский складчатый пояс): 40Ar-39Ar данные // IX Сибирская конференция молодых ученых по наукам о Земле: материалы конференции / Ин-т геологии и минералогии им. В. С. Соболева СО РАН, Ин-т нефтегазовой геологии и геофизики им. А. А. Трофимука СО РАН, Новосиб. гос. ун-т. - Новосибирск: ИПЦ НГУ, 2018а, с. 92-96. 
Ванин В.А., Чугаев А.В., Демонтерова Е.И., Гладкочуб Д.П., Мазукабзов А.М. Геологическое строение золоторудного поля Мукодек, Северное Забайкалье и источники вещества (Pb-Pb и Sm-Nd данные) // Геология и геофизика, 2018б, №9, с. 1345-1356.

Воронцов А.А., Ярмолюк В.В. Северо-Монгольская полихронная рифтовая система (этапы формирования, магматизм, источники расплавов, геодинамика) // Литосфера, 2004, №3, с. 17-32.

Врублевская Т.Т., Хубанов В.Б., Цыренов Б.Ц. Образование трахиандезитов и трахидацитов при смешении контрастных магм в сложных дайках (Западное Забайкалье) // Отечественная геология, 2013, № 3, с. 55-64.

Гордиенко И.В. Геодинамическая эволюция поздних байкалид и палеозоид складчатого обрамления юга Сибирской платформы // Геология и геофизика, 2006, т. 47, № 1, с. 53-70.

Гордиенко И.В. Палеозойский магматизм и геодинамика Центрально-Азиатского складчатого пояса. Москва: Издательство «Наука», 1987, 238 с.

Гордиенко И.В., Киселев А.И., Лашкевич В.В. Деламинация литосферы и связанный с ней магматизм в складчатых областях (на примере складчатого обрамления юга Сибирской платформы) // Проблемы глобальной геодинамики: Материалы теоретического семинара ОГГГГН РАН, 2000-2001 гг, Ред. Рундквиста Д.В. М.: ГЕОС, 2003, с. 185-199.

Дорошкевич А.Г., Избродин И.А., Рампилов М.О., Рипп Г.С., Ласточкин Е.И., Хубанов В.Б. Пермотриасовый этап щелочного магматизма Витимского плоскогорья (Западное Забайкалье) // Геология и геофизика, 2018, т. 59, № 9, с. 1325-1344.

Дорошкевич А.Г., Рипп Г.С., Сергеев С.А. U-Pb (SHRIMP-II) изотопное датирование цирконов из щелочных пород Витимской провинции, Западное Забайкалье // ДАН, $2012 а$. T. 443. № 1. С. 73-77.

Дорошкевич А.Г., Рипп Г.С., Сергеев С.А., Конопелько Д.Л. U-Pb геохронология Мухальского щелочного массива (Западное Забайкалье) // Геология и геофизика, 2012б. Т. 53. № 2. С. 219-225.

Занвилевич А.Н., Литвиновский Б.А., Андреев Г.В. Монголо-Забайкальская щелочногранитоидная провинция. Москва: Наука, 1985, 232 с.

Зоненшайн Л.П., Кузьмин М.И., Натапов Л.М. Тектоника литосферных плит территории СССР. М.: Недра, 1990. Кн. 1-2, 327 с., 334 с.

Избродин И.А., Дорошкевич А.Г., Рампилов М.О., Рипп Г.С., Ласточкин Е.А., Хубанов В.Б., Посохов В.Ф., Владыкин Н.В. Возраст, минералогическая и геохимическая характеристика пород Чининского щелочного массива (Западное Забайкалье) // Геология и геофизика, 2017, т. 58 (8), с. 1135-1156.

Карта магматических формаций юга Сибири и Северной Монголии. Масштаб 1 : 1500000. М.: МинГео, 1989.

Киселев А.И., Гордиенко И.В., Лашкевич В.В. Петрологические аспекты гравитационной нестабильности тектонически утолщенной литосферы // Тихоокеанская геология, 2004, т. 23, № 2, с. 20-29.

Ковач В.П., Сальникова Е.Б., Рыцк Е.Ю., Ярмолюк В. В., Котов А. Б., Анисимова И. В., Яковлева С. З., Федосеенко А. М., Плоткина Ю. В. Длительность формирования Ангаро-Витимского батолита: результаты геохронологических U-Pb исследований // ДАН, 2012, т. 444, № 2, с. 184-189.

Костицын Ю.А., Аносова M.O. U-Pb возраст экструзивных пород кальдеры Уксичан в Срединном хребте Камчатки - применение лазерной абляции к датированию молодых цирконов // Геохимия, 2013, № 2, с. 171-179.

Литвиновский Б.А., Занвилевич А.Н. Палеозойский гранитоидный магматизм Западного Забайкалья. - Новосибирск: Наука, 1976, 141 с. 
Литвиновский Б.А., Занвилевич А.Н., Алакшин А.М., Подладчиков Ю.Ю. Ангаро-Витимский батолит - крупнейший гранитоидный плутон. Новосибирск: Изд-во ОИГГМ СО РАН, 1993, 141 с.

Литвиновский Б.А., Занвилевич А.Н., Калманович М.А. Многократное смешение сосуществующих сиенитовых магм и его петрологическое значение. Усть-Хилокский массив, Забайкалье // Петрология, 1995а, т. 3, № 2, 133-157.

Литвиновский Б.А., Занвилевич А.Н., Ляпунов С.М., Биндеман И.Н., Дэвис А.М., Калманович М.А. Условия образования комбинированных базит-гранитоидных даек: Шалутинский массив, Забайкалье // Геология и Геофизика, 1995б, № 7, с. 3-23.

Лыхин Д.А., Коваленко В.И., Ярмолюк В.В., Сальникова Е.Б., Котов А.Б., Анисимова И.В., Плоткина Ю.В. Геохронология магматизма Ермаковского бериллиевого месторождения (Западное Забайкалье, Россия) // Геология рудных месторождений, 2010, т. 52, № 2, с. 126-152.

Мазукабзов А.М., Донская Т.В., Гладкочуб Д.П., Падерин И.П. Геодинамика Западно-Забайкальского сегмента Центрально-Азиатского складчатого пояса в позднем палеозое // Геология и геофизика, 2010, т. 51 (5), с. 615-628.

Масайтис В.Л. Девонский вулканизм Патомско-Вилюйского авлакогена: многократное плавление неоднородных мантийных источников // Региональная геология и металлогения, 2006, № 29, с. 27-49.

Покровский Б.Г., Жидков А.Я. Источники вещества ультракалиевых щелочных пород Сыннырского и Сакунского массивов по изотопным данным // Петрология, 1993, т. 1, № 2, с. 195-204.

Полянский О.П., Прокопьев А.В., Королева О.В., Томшин М.Д., Ревердатто В.В., Бабичев А.В., Свердлова В.Г., Васильев Д.А. Природа теплового источника базитового магматизма при формировании Вилюйского рифта на основе данных о возрасте дайковых поясов и численного моделирования // Геология и геофизика, 2018, т. 59, № 10, с. 15191541.

Резницкий Л.З., Школьник С.И., Иванов А.В., Демонтерова Е.И., Летникова Е.Ф., Хунг Ц., Чунг С. Герцинский икатский надвиг в забайкальском сегменте центрально-азиатского складчатого пояса // Геология и геофизика, 2015., т. 56, № 12, с. 2118-2133.

Рейф Ф.Г. Физико-химические условия формирования крупных гранитоидных масс Восточного Прибайкалья. Новосибирск: Наука, 1976, 88 с.

Руженцев С.В., Минина О.Р., Аристов В.А., Катюха И.П., Голионко Б.Г. Тектоника Икат-Багдаринской и Джидинской зон Западного Забайкалья // Проблемы тектоники Центральной Азии. М.: ГЕОС, 2005, с. 171-196.

Руженцев С.В., Минина О.Р., Некрасов Г.Е., Аристов В.А., Голионко Б.Г., Доронина Н.А., Лыхин Д.А. Байкало-Витимская складчатая система: строение и геодинамическая эволюция // Геотектоника, 2012, № 2, с. 3-28.

Рыцк Е.Ю., Амелин Ю.В., Ризванова Н.Г., Крымский Р.Ш., Митрофанов Г.Л., Митрофанова Н.Н., Переляев В.И., Шалаев В.С. Возраст пород Байкало-Муйского складчатого пояса // Стратиграфия и геологическая корреляция, 2001, т. 9, № 4, с. 3-15.

Рыцк Е.Ю., Андреев А.А., Сальникова Е.Б., Великославинский С.Д. Гранитоиды раннего палеозоя Северного Прибайкалья // Геодинамическая эволюция литосферы Центрально-Азиатского подвижного пояса (от океана к континенту): Материалы совещания. Вып. 16. - Иркутск: Институт земной коры СО РАН, 2018, с. 231-232.

Рыцк Е.Ю., Ковач В.П., Макеев А.Ф., Богомолов Е.С., Ризванова Н.Г. Восточная граница Прибайкальского коллизионного пояса: геологические, геохронологические и $\mathrm{Nd}$ изотопные данные // Геотектоника, 2009, №4, с. 16-26.

Рыцк Е.Ю., Неймарк Л.А., Амелин Ю.В. Возраст и геодинамические обстановки формирования палеозойских гранитоидов северной части Байкальской складчатой области // Геотектоника, 1998, № 5, с. 46-60. 
Салоп Л.И. Геология Байкальской горной области. Т. 2. М.: Недра, 1967, 515 с.

Титов А.В., Литвиновский Б.А., Занвилевич А.Н. РТ-условия и механизмы взаимодействия контрастных магм в Шалутинском плутоне, Забайкалье (по результатам исследования включений в минералах) // Геология и геофизика, 1998, т. 39, № 3, с. 350360.

Титов А.В., Литвиновский Б.А., Занвилевич А.Н., Шадаев М.Г. Явления гибридизации в комбинированных базит-лейкогранитных дайках Усть-Хилокского массива (Забайкалье) // Геология и Геофизика, 2000, т. 41, № 12, с.1714-1728.

Турутанов Е.X. Объемная модель Ангаро-Витимского батолита // Геодинамическая эволюция литосферы Центрально-Азиатского подвижного пояса (от океана к континенту). Материалы совещан., 2007, Вып. 5, т. 2, с. 131-132.

Хубанов В.Б., Буянтуев М.Д., Цыганков А.A. U-Pb изотопное датирование цирконов из PZ3-Mz магматических комплексов Забайкалья методом магнитно-секторной массспектрометрии с лазерным пробоотбором: процедура определения и сопоставление с SHRIMP данными // Геология и геофизика, 2016, т. 57, № 1, с. 241-258.

Цыганков А.А., Бурмакина Г.Н., Хубанов В.Б., Буянтуев М.Д. Геодинамика позднепалеозойского батолитообразования в Западном Забайкалье // Петрология. 2017, т. 25, № 4, с. 395-418.

Цыганков А.А., Литвиновский Б.А., Джань Б.М., Рейков М., Лю Д.И., Ларионов А.Н., Пресняков С.Л., Лепехина Е.Н., Сергеев С.А. Последовательность магматических событий на позднепалеозойском этапе магматизма Забайкалья (результаты U-Pb изотопного датирования) // Геология и геофизика, 2010, т. 51, № 9, с. 1249-1276.

Цыганков А.А., Матуков Д.И., Бережная Н.Г., Ларионов А.Н., Посохов В.Ф., Цыренов Б.Ц., Хромов А.А., Сергеев С.А. Источники магм и этапы становления позднепалеозойских гранитоидов Западного Забайкалья // Геология и геофизика. 2007, т. 48, № 1, с. 156-180.

Цыганков А.А., Хубанов В.Б., Бурмакина Г.Н. Этапы корообразования МонголоЗабайкальского сектора ЦАСП по данным U-Pb датирования цирконов из современных речных осадков // Фундаментальные проблемы тектоники и геодинамики. M-лы LII Тектонического совещания. Т. 2. Москва, ГЕОС, 2020, с. 391-395.

Цыганков А.А., Хубанов В.Б., Бурмакина Г.Н., Елбаев А.Л., Бурдуковский В.В. Соотношение мантийного и разновозрастного корового вещества в составе гранитоидов Забайкалья А-типа: петрологические и геодинамические следствия // Геодинамика и тектонофизика, 2019, т.10(3), с. 779-799.

Цыганков А.А., Хубанов В.Б., Буянтуев М.Д. Периодичность эндогенных событий Монголо-Забайкальского сектора ЦАСП по данным U-Pb датирования цирконов из современных речных осадков // Геодинамика и минерагения Северной и Центральной Азии Материалы V Всероссийской научно-практической конференции, посвященной 45летию Геологического института СО РАН. Ответственный редактор Е.В. Кислов. 2018, с. 380-382.

Цыганков А.А., Хубанов В.Б., Травин А.В., Лепехина Е.Н., Бурмакина Г.Н., Анциферова T.Н., Удоратина О.В. Позднепалеозойские габброиды Западного Забайкалья: U-Pb и Ar-Ar изотопный возраст, состав, петрогенезис // Геология и геофизика, 2016, т. 57, № 5, с. 1005-1027.

Цыганков А.А., Удоратина О.В., Бурмакина Г.Н., Гроув М. Новые данные U-Pb датирования цирконов и проблема длительности формирования Ангаро-Витимского гранитоидного батолита // ДАН, 2012. Т. 447. № 2. С. 204-209.

Чугаев А.В., Носова А.А., Абрамов С.С., Чернышев И.В., Бортников Н.С., Ларионов Ю.О., Гольцман Г.В., Вольфсон А.А. Раннепермский этап формирования золоторудных месторождений Северо-Восточного Забайкалья: изотопно- 
геохронологические (Rb-Sr и 39Ar-40Ar) данные по Уряхскому рудному полю // ДАН, 2015. № 6. T. 463. С. 700-704.

Шадаев М.Г., Хубанов В.Б., Посохов В.Ф. Новые данные о Rb-Sr возрасте дайковых поясов в Западом Забайкалье // Геология и Геофизика, 2005, т. 46, № 7, с. 723-730.

Шарпенок Л. Н., Костин А. Е., Кухаренко Е. А. ТАS-диаграмма сумма щелочей кремнезем для химической классификации и диагностики плутонических пород // Регион. геология и металлогения, 2013, № 56, с. 40-50.

Шацилло А.В., Федюкин И.В., Паверман В.И. Палеомагнетизм позднепалеозойских гранитов Ангаро-Витимского батолита и вмещающих пород Байкало-Патомской складчатой области: тектонические следствия // Геология и геофизика, 2014, т. 55, № 7, с. 1093-1111.

Ярмолюк В.В., Будников С.В., Коваленко В.И., Антипин В.С., Горегляд А.В., Сальникова Е.Б., Котов А.Б., Козаков И.К., Ковач В.П., Яковлева С.З., Бережная Н.Г. Геохронология и геодинамическая позиция Ангаро-Витимского батолита // Петрология, 1997a, т. 5, № 5, с. 451-466.

Ярмолюк В.В., Коваленко В.И., Котов А.Б., Сальникова Е.Б. Ангаро-Витимский батолит: к проблеме геодинамики батолитообразования в Центрально-Азиатском складчатом поясе // Геотектоника, 1997б, № 5, с. 18-32.

Ярмолюк В.В., Кузьмин М.И., Козловский А.М. Позднепалеозойскийраннемезозойский внутриплитный магматизм Северной Азии: траппы, рифты, батолитыгиганты и геодинамика их формирования // Петрология, 2013, т. 21, №2, с. 115-142.

Bryan S.E. Silicic Large Igneous Provinces // Episodes. 2007. V.30 (1). P.20-31.

Bryan S.E., Ernst R.E. Revised definition of Large Igneous Provinces (LIPs) // EarthScience Reviews, 2008, v. 86, pp. 175-202.

Condie K.C., Belousova E., Griffin W.L., Sircombe K.N. Granitoid events in space and time: Constraints from igneous and detrital zircon age spectra // Gondwana Research, 2009, v.15, pp. 228-242.

Donskaya T.V., Gladkochub D.P., Mazukabzov A.M., Ivanov A.V. Late Paleozoic Mesozoic subduction-related magmatism at the southern margin of the Siberian continent and the 150 million-year history of the Mongol-Okhotsk Ocean // J. Asian Earth Sci., 2013, v. 62, pp. 79-97.

Doroshkevich, A.G., Ripp, G.S., Izbrodin, I.A., Savatenkov, V.M. Alkaline magmatism of the Vitim province, West Transbaikalia, Russia: age, mineralogical, geochemical and isotope (O, C, D, Sr, Nd) data // Lithos, 2012, v. 152, pp. 157-172.

Griffin W.L., Powell W.J., Pearson N.J., O'Reilly S.Y. GLITTER: Data reduction software for laser ablation ICP-MS // Laser Ablation ICP-MS in the Earth Sciences. Ed. P.J. Sylvester. Mineralogical association of Canada short course series. 2008, v. 40, pp. 204-207.

Ivanov A.V., Vanin V.A., Demonterova E.I. Gladkochub D.P., Donskaya T.V., Gorovoy V.A. Application of the 'no fool's clock' to dating the Mukodek gold field, Siberia, Russia // Ore Geology Reviews, 2015, v. 69, pp. 352-359.

Izbrodin I., Doroshkevich A., Rampilov M., Elbaev A., Ripp G. Late Paleozoic alkaline magmatism in Western Transbaikalia, Russia: Implications for magma sources and tectonic settings // Geoscience Frontiers, 2020, v. 11, pp. 1289-1303.

Jackson S. E., Pearson N. J., Griffin W. L. and Belousova, E. A. The application of laser ablation-inductively coupled plasma-mass spectrometry to in situ U-Pb zircon geochro-nology // Chemical Geology, 2004, v. 211, pp. 47-69.

Liégeois J.P., Black R. Alkaline magmatism subsequent to collision in the Pan-African belt of the Adrar des Iforas // Alkaline igneous rocks / Eds. J.G. Fitton, B.G.J. Upton. Geol. Soc. London, Special Publ., 1987, v. 30, pp. 381-401.

Litvinovsky B. A., Zanvilevich A. N., Katzir Y. Formation of composite dykes by contact remelting and magma mingling: The Shaluta pluton, Transbaikalia (Russia) // Journal of Asian Earth Sciences, 2012, v. 60 (22), pp. 18-30. 
Litvinovsky B.A., Tsygankov A.A., Jahn B.M., Katzir Y., Be’eri-Shlevin Y. Origin and evolution of overlapping calc-alkaline and alkaline magmas: The Late Palaeozoic postcollisional igneous province of Transbaikalia (Russia) // Lithos, 2011, v. 125, pp. 845-874

Litvinovsky B.A., Zanvilevich A.N., Wickham S.M., Jahn B.M., Vapnik Y., Kanakin S.V., Karmanov N.S. Composite dikes in four successive granitoid suites from Transbaikalia, Russia: The effect of silicic and mafic magma interaction on the chemical features of granitoids // Journal of Asian Earth Sciences, 2017, v. 136, pp. 16-39.

Ludwig K.R. User's Manual for Isoplot 3.70: A Geochronological Toolkit for Microsoft Excel. Berkeley Geochronology Center. Spec. Publ. 4, 2008, 76 p.

Pavlov V., Bachtadse V., Mikhailov V. New Middle Cambrian and Middle Ordovician palaeomagnetic data from Siberia: Llandelian magnetostratigraphy and relative rotation between the Aldan and Anabar-Angara blocks // Earth Planet. Sci. Lett., 2008, v. 276, pp. 229-242.

Powerman, V., Shatsillo, A., Coe, R., Zhao, Xixi, Gladkochub, D., Buchwaldt, R., Pavlov, V. Palaeogeography of the Siberian platform during middle Palaeozoic times ( 450-400 Ma): new palaeomagnetic evidence from the Lena and Nyuya rivers // Geophysical Journal International, 2013, v. 194, pp. 1412-1440.

Reichow M.K., Litvinovsky B.A., Parrish R.R., Saunders A.D. Multi-stage emplacement of alkaline and peralkaline syenite-granite suites in the Mongolian-Transbaikalian belt, Russia: Evidence from U-Pb geochronology and whole rock geochemistry // Chemical Geology, 2010, v. 273 (1-2), pp. 120-135.

Rickwood P.C. Boundary lines within petrologic diagrams which use oxides of major and minor elements // Lithos, 1989, v. 22, pp. 247-263.

Sláma J., Košler J., Condon D.J., Crowley J.L., Gerdes A., Hanchar J.M., Horstwood M.S.A., Morris G.A., Nasdala L., Norberg N., Schaltegger U., Schoene B., Tubrett M.N., Whitehouse M.J. Plesovice zircon - A new natural reference material for $\mathrm{U}-\mathrm{Pb}$ and $\mathrm{Hf}$ isotopic microanalysis // Chem. Geol., 2008, v. 249, pp. 1-35.

Stacey J.S., Kramers J.D. Approximation of terrestrial lead isotope evolution by a twostage model // Earth and Planetary Science Letters, 1975, v. 26 (2), pp. 207-221.

Suvorov V.D., Mishenkina Z.M., Petrick G.V, Sheludko I.F., Seleznev V.S., Solovyov V.M. Structure of the crust in the Baikal rift zone and adjacent areas from Deep Seismic Sounding data // Tectonophysics, 2002, v. 351, p. 61-74.

Wiedenbeck M., Allé P., Corfu F., Griffin W.L., Meier M., Oberli F., van Quadt A., Roddick J.C., Spiegel W. Three natural zircon standards for U-Th-Pb, Lu-Hf, trace element and REE analyses // Geostandards Newsletter, 1995, v. 19, pp. 1-23.

Yarmolyuk V.V., Kuzmin M.I., Ernst R.E. Intraplate geodynamics and magmatism in the evolution of the Central Asian Orogenic Belt // J. Asian Earth Sci., 2014, v. 93, pp. 158-179.

Zorin, Yu.A. Geodynamics of the western part of the Mongolia-Okhotsk collisional belt, Trans-Baikal region (Russia) and Mongolia // Tectonophysics, 1999, v. 306, pp. 33-56. 
Подписи к рисункам

Рисунок 1. Схема расположения позднепалеозойских гранитоидов Западного Забайкалья (Ангаро-Витимский батоллит). Составлена на основе [Карта магматических формаций..., 1989; Цыганков и др., 2010]. 1 - щелочно-полевошпатовые и щелочные граниты и сиениты Монголо-Забайкальского вулкано-плутонического пояса (раннекуналейский (280 - 273 млн лет) и позднекуналейский (230 - 210 млн лет) комплексы); 2 - высококалиевая монцонит-сиенит-кварцевосиенитовая с синплутоническими базитами интрузивная серия (нижнеселенгинский комплекс - 285-278 млн лет); 3 - переходные, от высококалиевых известково-щелочных до субщелочных (alkaline) граниты и кварцевые сиениты с синплутоническими базитами (зазинский комплекс - 305 - 285 млн лет); 4 - высококалиевые известково-щелочные кварцевые монцониты, кварцевые сиениты и габброиды (чивыркуйский комплекс - 305 - 285 млн лет); 5 - известково-щелочные граниты авто- и аллохтонной фаций (баргузинский комплекс, 325 - 290 млн лет); 6 - места отбора проб, в которых проводилось U-Pb изотопно-геохронологическое датирование цирконов предшественниками; 6 - обозначена площадь исследования (рис. 2). Пунктирными линиями обозначены предполагаемые контуры позднепалеозойских рифтовых структур: I - Сыннырская, II - Сайженская, III Уда-Витимская [Yarmolyuk et al., 2014]. На врезке: схема террейнов Байкальской складчатой области [Булгатов, Гордиенко, 1999] с изменениями: 1 - Северо-Азиатский кратон (AR-PR1); 2 - пассивная окраина Северо-Азиатского кратона (Байкало-Патомский покровно-складчатый пояс, R3-PZ); 3 - кратонные террейны (AR-PR1); 4 метаморфические террейны (PR1-PZ); 5 - океанические террейны (R1-2, V-€1); 6 островодужные террейны (R2-3, $\mathrm{E} 1)$; флишевые террейны (турбидитовые бассейны): 7 (R1-2 - V- E1), 8 - (D-C1). NSC - Северо-Азиатский кратон; террейны кратонные: CH Чуйский, MS - Муйский, AM - Амалатский, NR - Нечерский; пассивной окраины: BB Бодайбинский; метаморфические: HD - Хамардабанский, OL - Ольхонский, ML Малханский, ZG - Заганский, океанические: PR - Парамский; островодужные: ER Еравнинский, KL - Келянский, DN - Джидинский; турбидитовые, BR-VV - БаргузиноВерхневитимский, DR - Даурский, ON - Ононский.

Рисунок 2. Сема геологического строения бассейна верхнего течения р. Агаракан. Составлена на основе составлена на основе Геологической карты СССР масштаба 1:200000, лист О-49-XXXVI с изменениями авторов. 1 - кайнозойские отложения; бургузинский комплекс (3-5): 2 - габброиды; 3 - мелко-, среднезернистые лейкограниты, 4 - порфировидные мелкозернистые граниты, 5 - гнейсовидные гранитоиды, 6 - среднекрупнозернистые массивные и порфировидные (Kfs) граниты и граносиениты; 7 метаморфические породы ( $\mathrm{PR}_{3}-\mathrm{PZ}_{1-2}$ ?); 8 - разломы; 9 - водосборный бассейн верховьев р. Ангаракан и р. Итыкит.

Рисунок 3. Классификационные диаграммы K2O-SiO2 (граничные линии, по [Rickwood, 1989] (а) и агпаитовый индекс NK/A-SiO2 (границы полей, по [Liégeois, Black, 1987] (б) для гранитоидов верховьев р. Ангаракан (черные квадраты) и известково-щелочных гранитоидов баргузинского комплекса (ромбики) по [Цыганков 2014].

Рисунок 4. Средневзвешенный конкордантный ${ }^{207} \mathrm{~Pb} /{ }^{235} \mathrm{U}-{ }^{206} \mathrm{~Pb} /{ }^{238} \mathrm{U}$ возраст (графики слева) цирконов из известково-щелочных гранитов бассейна верховьев р. Ангаракан и р. Итыкит и средневзвешенный возраст по отношению ${ }^{206} \mathrm{~Pb} /{ }^{238} \mathrm{U}$, скорректированный на обыкновенный свинец методом ${ }^{207} \mathrm{~Pb}$ (графики справа). 


\section{Продолжение рисунка 4.}

Рисунок 5. U-Pb изотопный LA-ICP-MS возраст цирконов из известково-щелочных граносиенитов бассейна верховьев р. Ангаракан и р. Итыкит. Слева приведены графики с изотопными отношениями ${ }^{207} \mathrm{~Pb} /{ }^{235} \mathrm{U}$ и ${ }^{206} \mathrm{~Pb} /{ }^{238} \mathrm{U}$ и конкордией, справа средневзвешенный позднепалеозойский возраст по отношению ${ }^{206} \mathrm{~Pb} /{ }^{238} \mathrm{U}$, скорректированный на обыкновенный свинец методом ${ }^{207} \mathrm{~Pb}$ коррекции.

Рисунок 6. Графики с изотопными отношениями ${ }^{207} \mathrm{~Pb} /{ }^{235} \mathrm{U}$ и ${ }^{206} \mathrm{~Pb} /{ }^{238} \mathrm{U}$ и конкордией (справа) и гистограммы и кривые плотности вероятности распределения возрастов (слева) для цирконов из проб гранитов КМ-05-15 и КМ-09-15.

Рисунок 7. Гистограммы и кривые плотности вероятности распределения возрастов (слева) для обломочных цирконов (SHL-01-15) (а, б) и магматических цирконов (в, г).

Рисунок 8. Гистограммы распределения U-Pb возрастов цирконов из позднепалеозойских магматических пород Западного Забайкалья [Цыганков и др., 2017] с добавлениями. Гранитоидные комплексы (а): 1 - раннекуналейский, 2 нижнеселенгинский, 3 - зазинский, 4 - чивыркуйский, 5 - баргузинский; Мафические и щелочные ассоциации (б): 1 - габбро-монцонитовые массивы, 2 - щелочные породы.

Использованы данные, опубликованные в [Ярмолюк и др., 1997; Цыганков и др., 2007, 2010, 2012, 2016, 2017; Ковач и др., 2012; Дорошкевич и др., 2012а, 2012б; Хубанов и др., 2016; Izbrodin et al., 2020]. Для массивов, в которых имеется более одного определения возраста (датированы разные фазы или фации), в случае их совпадения в пределах погрешности анализа, принят средний возраст. Звездочками показаны данные настоящей работы (по шести пробам гранитов баргузинского комплекса, принадлежащих одному массиву, показан средний возраст 306 млн. лет); стрелки с цифрами - пики по детритовым цирконам.

Рисунок 9. Палеогеодинамическая модель развития позднепалеозойского магматизма в Забайкалье. 1 - астеносферная мантия и направления ее восходящего движения (мантийного плюма); 2 - литосферная мантия и направления ее движения при подъеме плюма; 3 - континентальная кора кратонных блоков и направления их движения; 4 континентальная кора Забайкалья и тренды сдвиго-взбросового и сдвиго-сбросового смещения; 5 - область генерации мантийных магм; 6 - промежуточные камеры эволюции мантийных магм и их взаимодействия с коровым вещестовм, светлые стрелки - подъем флюидов из мантийных очагов, темные стрелки - подъем флюидов из нижнекоровых очагов; 7 -область выплавления известково-щелочных гранитоидных магм в средней коре; 8 - магматические камеры (тела) гранитоидных магм с мантинйыми и мантийно-коровыми изотопно-геохимическими метками. 
Табл. 1. Параметры настроек оборудования LA-ICP-MS для U-Pb изотопного датирования цирконов

\begin{tabular}{|c|c|}
\hline \multicolumn{2}{|c|}{ Лазерная абляция } \\
\hline Тип лазера & Nd-YAG \\
\hline Производитель / модель & New Wave Research / UP-213 \\
\hline Длина волны излучения & $213 \mathrm{Hм}$ \\
\hline Размер пучка излучения & 25 мКм \\
\hline Частота импульсов & 10 Гц \\
\hline Уровень выхода энергии & $45-50 \%$ \\
\hline Мощность излучения & 0,018-0,022 мДж \\
\hline Плотность потока энергии & 3,5-4 Дж/см² \\
\hline \multicolumn{2}{|c|}{ Масс-спектрометр } \\
\hline Тип масс-спектрометра & Магнитно-секторный \\
\hline Производитель / модель & Thermo Scientific / Element XR \\
\hline Энергия ионизации & 1180 Вт \\
\hline \multicolumn{2}{|l|}{ Газовые потоки: } \\
\hline Охлаждающий (Ar) & 16 л/мин \\
\hline Вспомогательный (Ar) & 0.9 л/мин \\
\hline Транспортный (Не) & 1 л/мин \\
\hline Пробоподающий (Ar) & 1.1 л/мин \\
\hline Разрешение & Низкое \\
\hline Режим сканирования & E-scan \\
\hline Мертвое время детектора (Dead Time) & 15 нс \\
\hline \multicolumn{2}{|l|}{ Метод измерения: } \\
\hline Измеряемые массы (изотопы) & 202, 204, 206, 207, 208, 232, 238 \\
\hline Режим регистрации сигналов & $\begin{array}{l}\text { Аналоговый режим - для масс } 232 \text { и } \\
\text { 238, режим счета (Counting) - для }\end{array}$ \\
\hline $\begin{array}{l}\text { Окно сканирования массы (Mass } \\
\text { Windows) }\end{array}$ & $\begin{array}{l}\text { других масс } \\
\text { 2\% - для } 202 \text { и 204; 4\% - 206, 207, } \\
\text { 208, } 232 \text { и } 238 \text { масс }\end{array}$ \\
\hline $\begin{array}{l}\text { Время задержки магнита (Settling } \\
\text { Time) }\end{array}$ & 0.001 с для каждой массы \\
\hline Время измерения (Sample Time) & $\begin{array}{l}0.001 \text { с для } 202 \text { и } 204 \text { массы; } 0.0015 \text { - } \\
232 \text { и 238; } 0.002 \text { с - 206, } 207 \text { и 208; }\end{array}$ \\
\hline $\begin{array}{l}\text { Количество сигналов в пике } \\
\text { (Samples Per Peak) }\end{array}$ & 100 - для каждой массы \\
\hline $\begin{array}{l}\text { Способ интегрирования сигнала } \\
\text { (Integration Tyре) }\end{array}$ & Среднеарифметический \\
\hline $\begin{array}{c}\text { Количество сканирований при } \\
\text { одном измерении (Runs) }\end{array}$ & 800 \\
\hline
\end{tabular}


Табл. 2. Химический состав представительных проб известково-щелочных гранитоидов баргузинского комплекса из верховьев р. Ангаракан и ее притока р. Итыкит (Западное Забайкалье)

\begin{tabular}{|c|c|c|c|c|c|c|c|c|c|}
\hline \multirow{2}{*}{ Компонент } & Km-04-15 & Km-06-15 & Km-01-15 & $\mathrm{Km}-02-15$ & Km-09-15 & Km-07-15 & Km-10-15 & Km-03-15 & Km-05-15 \\
\hline & 1 & 2 & 3 & 4 & 5 & 6 & 7 & 8 & 9 \\
\hline $\mathrm{SiO}_{2}$, мас.\% & 64.90 & 67.50 & 68.90 & 70.00 & 70.50 & 71.00 & 72.30 & 72.60 & 73.80 \\
\hline $\mathrm{TiO}_{2}$ & 0.51 & 0.48 & 0.33 & 0.37 & 0.21 & 0.41 & 0.21 & 0.27 & 0.12 \\
\hline $\mathrm{Al}_{2} \mathrm{O}_{3}$ & 17.10 & 15.80 & 16.10 & 16.30 & 16.20 & 15.20 & 15.40 & 14.90 & 14.80 \\
\hline $\mathrm{Fe}_{2} \mathrm{O}_{3}$ & 1.93 & 1.78 & 0.18 & 0.57 & 0.95 & 1.20 & 0.74 & 0.84 & 0.47 \\
\hline $\mathrm{FeO}$ & 1.58 & 1.39 & 0.89 & 0.89 & 0.50 & 0.81 & 0.58 & 0.58 & 0.35 \\
\hline $\mathrm{MnO}$ & 0.11 & 0.13 & 0.09 & 0.04 & 0.07 & 0.06 & 0.04 & 0.04 & 0.04 \\
\hline $\mathrm{MgO}$ & 0.72 & 0.61 & 0.44 & 0.36 & 0.22 & 0.37 & 0.25 & 0.28 & 0.22 \\
\hline $\mathrm{CaO}$ & 2.98 & 2.65 & 1.87 & 1.77 & 1.93 & 1.26 & 1.09 & 1.11 & 1.16 \\
\hline $\mathrm{Na}_{2} \mathrm{O}$ & 4.99 & 4.57 & 4.57 & 4.86 & 4.76 & 4.44 & 4.47 & 4.22 & 4.18 \\
\hline $\mathrm{K}_{2} \mathrm{O}$ & 4.20 & 4.79 & 4.46 & 3.89 & 4.16 & 4.20 & 4.10 & 4.35 & 4.28 \\
\hline $\mathrm{P}_{2} \mathrm{O}_{5}$ & 0.14 & 0.07 & 0.08 & 0.07 & 0.03 & 0.01 & 0.03 & 0.03 & 0.03 \\
\hline П.п.п. & 0.78 & 0.51 & 0.40 & 0.66 & 0.20 & 0.69 & 0.60 & 0.44 & 0.36 \\
\hline Сумма & 99.94 & 100.28 & 99.88 & 99.78 & 99.70 & 99.72 & 99.78 & 99.63 & 99.78 \\
\hline A/CNK & 0.94 & 0.90 & 1.02 & 1.06 & 1.02 & 1.07 & 1.12 & 1.09 & 1.09 \\
\hline NK/A & 0.75 & 0.80 & 0.77 & 0.75 & 0.76 & 0.78 & 0.77 & 0.78 & 0.78 \\
\hline $\mathrm{Ba}, \Gamma / \mathrm{T}$ & 3477 & 2311 & 2234 & 2898 & 1868 & 2695 & 2864 & 2722 & 1740 \\
\hline $\mathrm{Rb}$ & 89 & 102 & 100 & 106 & 92 & 110 & 79 & 104 & 108 \\
\hline $\mathrm{Sr}$ & 1400 & 968 & 979 & 1380 & 852 & 1075 & 1095 & 924 & 707 \\
\hline $\mathrm{Ga}$ & 17.5 & 17.9 & 17.0 & 17.5 & 17.7 & 18.2 & 18.0 & 16.9 & 15.8 \\
\hline $\mathrm{Nb}$ & 8.5 & 16.3 & 9.4 & 4.8 & 7.0 & 10.4 & 7.2 & 6.3 & 4.5 \\
\hline $\mathrm{Hf}$ & 4.5 & 4.0 & 1.8 & 4.7 & 2.5 & 4.4 & 3.9 & 5.0 & 3.8 \\
\hline
\end{tabular}




\begin{tabular}{|c|c|c|c|c|c|c|c|c|c|}
\hline $\mathrm{Zr}$ & 168 & 185 & 149 & 190 & 135 & 245 & 154 & 180 & 130 \\
\hline$Y$ & 19 & 25 & 18 & 6 & 11 & 12 & 9 & 8 & 3 \\
\hline Th & 6.60 & 9.40 & 9.60 & 11.50 & 4.60 & 12.40 & 11.10 & 11.30 & 13.50 \\
\hline $\mathrm{U}$ & 3.00 & 2.40 & 2.60 & 4.30 & 2.30 & 2.50 & 1.90 & 1.60 & 2.70 \\
\hline $\mathrm{Ni}$ & 1.8 & 0.9 & 1.0 & 1.2 & 0.9 & 0.9 & 1.1 & 1.8 & 2.0 \\
\hline $\mathrm{Cu}$ & 5 & 4 & 3 & 4 & 4 & 5 & 3 & 4 & 4 \\
\hline $\mathrm{Pb}$ & 24 & 27 & 25 & 4 & 31 & 33 & 30 & 33 & 36 \\
\hline $\mathrm{Zn}$ & 45 & 65 & 47 & 42 & 33 & 50 & 44 & 3 & 30 \\
\hline $\mathrm{F}$ & 0.15 & 0.13 & 0.12 & 0.12 & 0.03 & 0.07 & 0.03 & 0.04 & 0.04 \\
\hline $\mathrm{La}$ & 52 & 54 & 40 & 49 & 36 & 55 & 55 & 50 & 45 \\
\hline $\mathrm{Ce}$ & 104 & 94 & 79 & 92 & 56 & 115 & 75 & & 65 \\
\hline
\end{tabular}

Примечание. 1 и 2 - гранисиениты, 3-9 - граниты; NK/A = $\left(\mathrm{Na}_{2} \mathrm{O}+\mathrm{K}_{2} \mathrm{O}\right) / \mathrm{Al}_{2} \mathrm{O}_{3}$, мол.\%; $\mathrm{A} / \mathrm{CNK}=\mathrm{Al}_{2} \mathrm{O}_{3} /\left(\mathrm{CaO}_{+} \mathrm{Na}_{2} \mathrm{O}+\mathrm{K}_{2} \mathrm{O}\right)$, мол.\%; пробел - нет данных.

Анализ содержаний петрогенных элементов выполнен методом «мокрой химии» (аналитики Б.Б. Лыгденова,О.В. Корсун), элементы-примеси - методом РФА на спектрометре ARL PERFORM’X (аналитик Б.Ж. Жалсараев) в ЦКП «Аналитический центр минералого-геохимических и изотопных исследований» ГИН СО РАН, г. Улан-Удэ. 
Табл. 3. Сводная таблица возрастов магматических цирконов из известково-щелочных гранитоидов баргузинского комплекса и обломочных цирконов из современного песка (бассейн верховьев р. Ангаракан)

\begin{tabular}{|c|c|c|c|c|c|}
\hline № & Проба & Координаты & Порода, осадок & $\begin{array}{l}\text { Возраст, } \\
\text { млн лет }\end{array}$ & $\begin{array}{l}\text { Количество } \\
\text { измерений }\end{array}$ \\
\hline 1 & KM-02-15 & $\begin{array}{l}\text { 56¹8'16.6" с.ш. } \\
113^{\circ} 22^{\prime} 56.9^{\prime \prime} \text { в.Д. }\end{array}$ & $\begin{array}{l}\text { Массивный } \\
\text { среднезернистый Bt- } \\
\text { гранит }\end{array}$ & $304 \pm 3 *$ & 19 \\
\hline 2 & KM-04-15 & $\begin{array}{l}\text { 56¹8'15.2" с.ш. } \\
113^{\circ} 24^{\prime} 21.3^{\prime \prime} \text { в.Д. }\end{array}$ & $\begin{array}{l}\text { Массивный } \\
\text { среднезернистый Amf- } \\
\text { граносиенит }\end{array}$ & $310 \pm 2$ & 24 \\
\hline 3 & KM-07-15 & $\begin{array}{l}56^{\circ} 12^{\prime} 51.7^{\prime \prime} \text { с.ш. } \\
113^{\circ} 28^{\prime} 47.5^{\prime \prime} \text { в.Д. }\end{array}$ & $\begin{array}{l}\text { Массивный } \\
\text { среднезернистый Bt- } \\
\text { гранит }\end{array}$ & $307 \pm 2$ & 27 \\
\hline 4 & KM-10-15 & $\begin{array}{l}\text { 56¹8'3.7" с.ш. } \\
113^{\circ} 17^{\prime} 44.9^{\prime \prime} \text { в.Д. }\end{array}$ & $\begin{array}{l}\text { Порфировидный (KFS) } \\
\text { крупнозернистый Bt- } \\
\text { гранит }\end{array}$ & $305 \pm 3$ & 16 \\
\hline 5 & KM-01-15 & $\begin{array}{l}\text { 56¹8'10.4" с.ш. } \\
113^{\circ} 22^{\prime} 59.6^{\prime \prime} \text { в.Д. }\end{array}$ & $\begin{array}{l}\text { Порфировидный (KFS) } \\
\text { среднезернистый } \\
\text { граносиенит (Amf-Bt) }\end{array}$ & $\begin{array}{c}303 \pm 3 \\
472 \pm 15 \\
772 \pm 9\end{array}$ & $\begin{array}{c}28 \\
1 \\
1\end{array}$ \\
\hline 6 & KM-06-15 & $\begin{array}{l}\text { 56¹3'51.1" с.ш. } \\
113^{\circ} 25 ' 22.6^{\prime \prime ~ в . д . ~}\end{array}$ & $\begin{array}{l}\text { Порфировидный (KFS) } \\
\text { среднезернистый } \\
\text { граносиенит (Amf) }\end{array}$ & $\begin{array}{c}306 \pm 3 \\
444 \pm 24\end{array}$ & $\begin{array}{c}16 \\
2\end{array}$ \\
\hline 7 & KM-05-15 & $\begin{array}{l}\text { 56¹4'08.8" с.ш. } \\
113^{\circ} 24^{\prime 22.6 " ~ в . Д . ~}\end{array}$ & $\begin{array}{l}\text { Массивный } \\
\text { среднезернистый Bt- } \\
\text { гранит }\end{array}$ & $\begin{array}{c}270-316^{* *} \\
280^{* * *} \\
306 \\
314\end{array}$ & $\begin{array}{l}29 \\
14 \\
6 \\
4\end{array}$ \\
\hline 8 & KM-09-15 & $\begin{array}{l}56^{\circ} 19^{\prime} 12.3^{\prime \prime} \text { с.ш. } \\
113^{\circ} 16^{\prime} 2.6^{\prime \prime} \text { в.Д. }\end{array}$ & $\begin{array}{l}\text { Мелкозернистый } \\
\text { лейкогранит }\end{array}$ & $\begin{array}{c}293-884 \\
320 \\
708\end{array}$ & $\begin{array}{c}30 \\
4 \\
4\end{array}$ \\
\hline 9 & Shl-01-15 & $\begin{array}{l}56^{\circ} 17^{\prime} 22.2^{\prime \prime} \text { с.ш. } \\
113^{\circ} 20^{\prime} 22.2^{\prime \prime} \text { в.Д. }\end{array}$ & $\begin{array}{l}\text { Среднезернистый } \\
\text { аркозовый песок }\end{array}$ & $\begin{array}{c}260-1875 \\
782 \\
423 \\
314 \\
285\end{array}$ & $\begin{array}{c}140 \\
16 \\
21 \\
30 \\
21\end{array}$ \\
\hline
\end{tabular}

Примечание. *(для 1-6) - средневзвешенные значения конкордантного возраста, рассчитанные с помощью Isoplot (рис. 4-5); **(для 7-9) - общий диапазон разброса возрастов; ***(для 7-9) - возрастные пики, рассчитанные с помощью AGE PICK (рис. 6-9). Полная таблица измеренных изотопных отношений и возрастов доступна по запросу к В.Б. Хубанову (khubanov@mail.ru). 


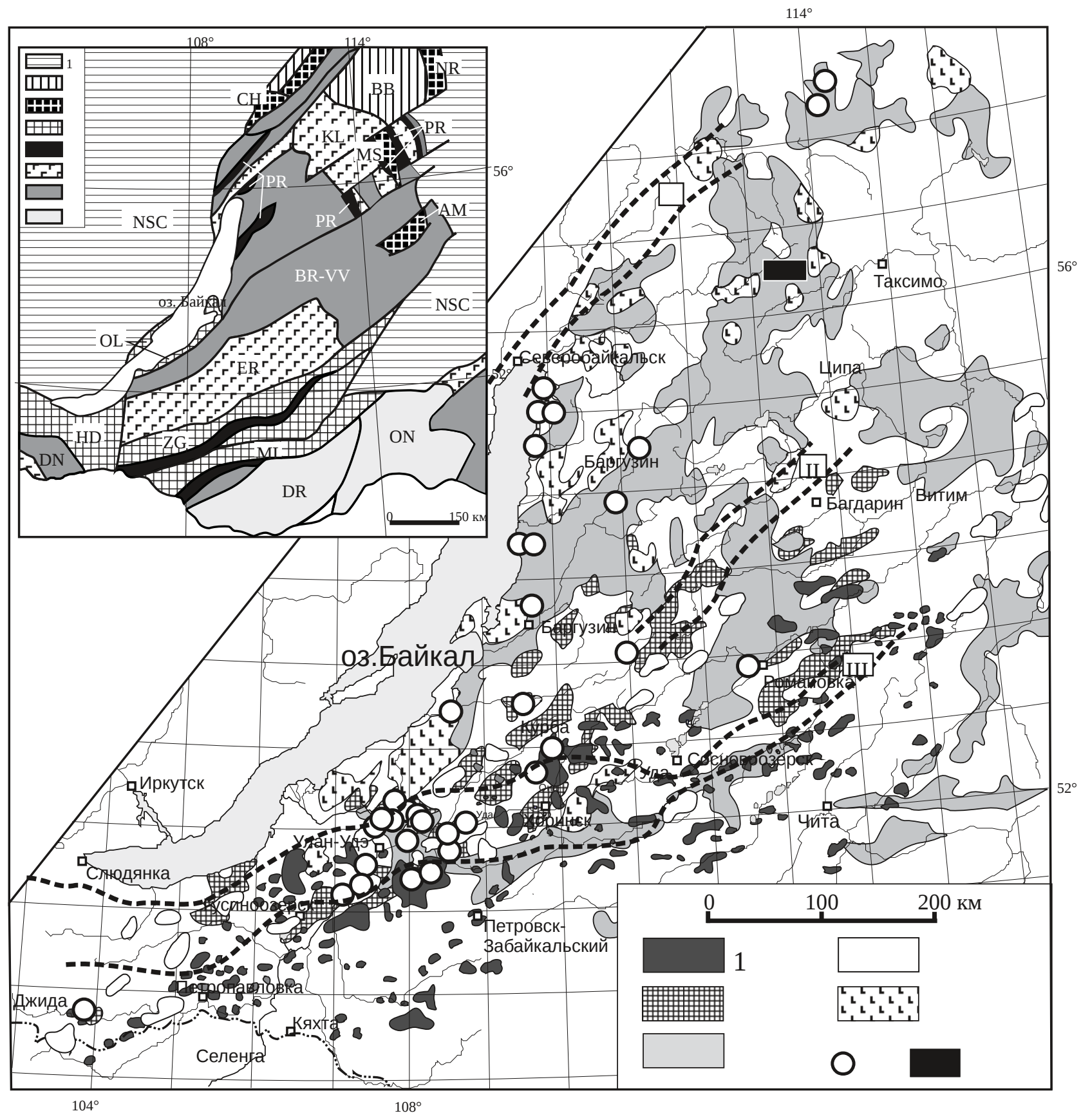




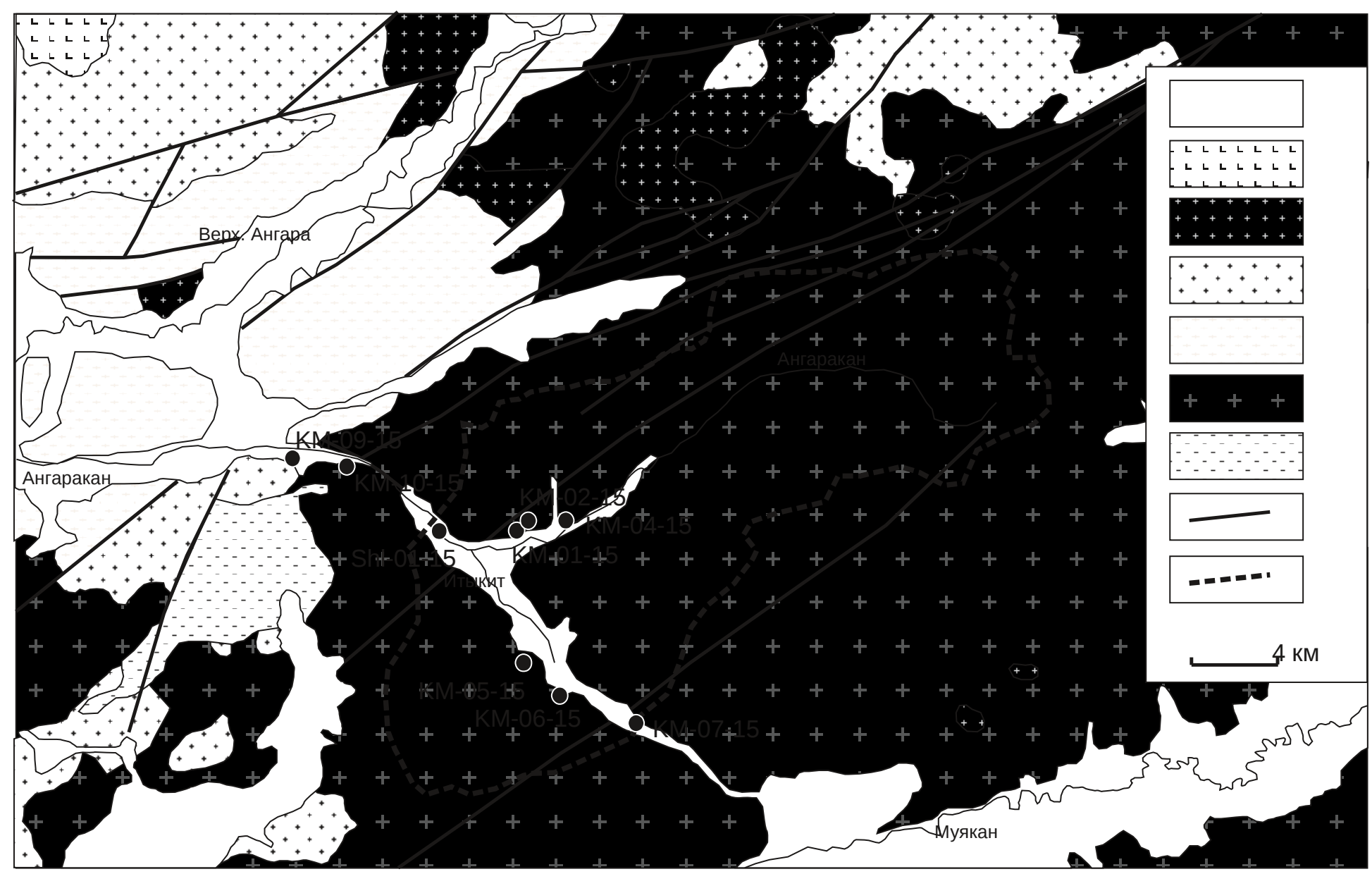



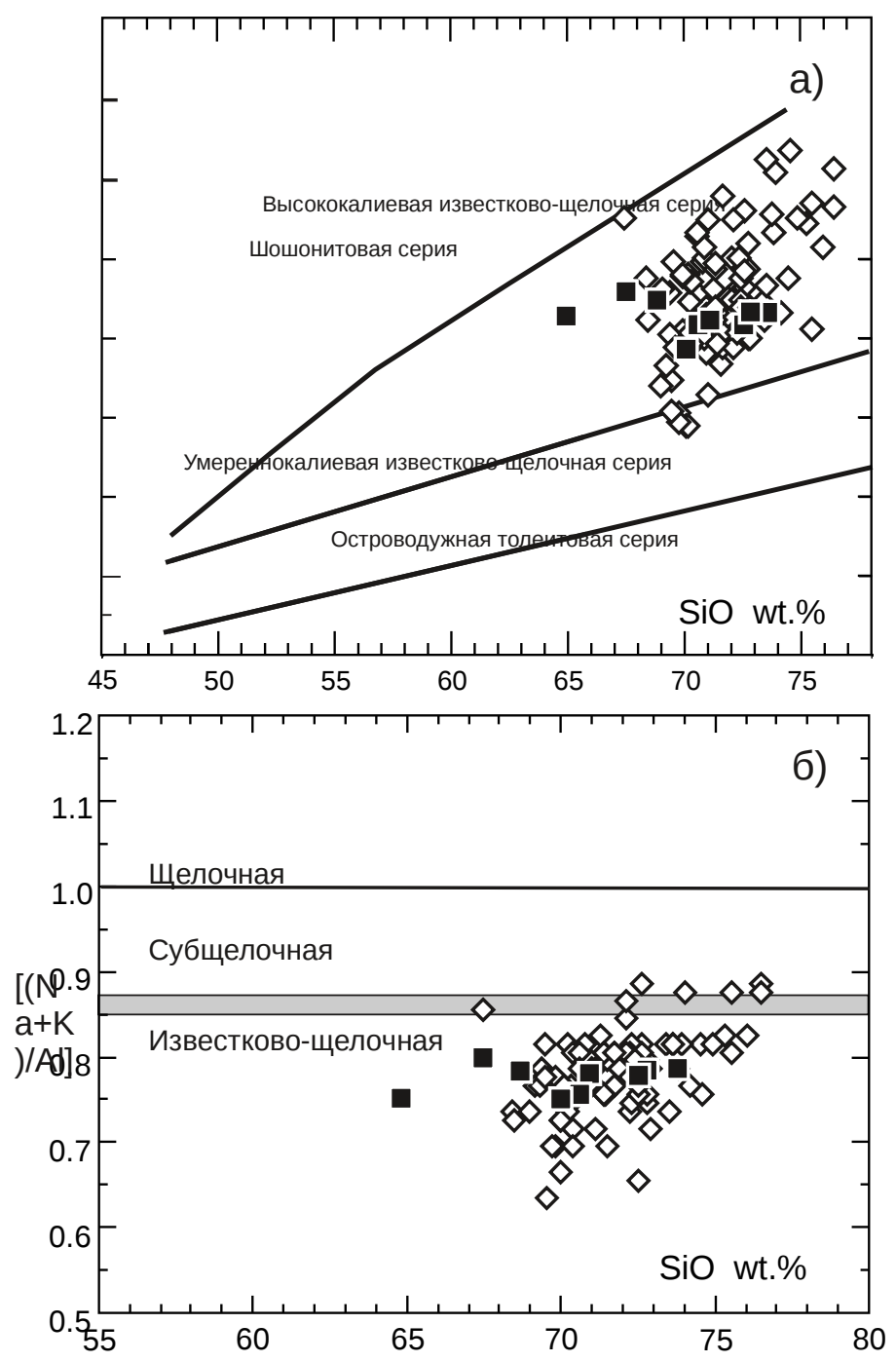
a)

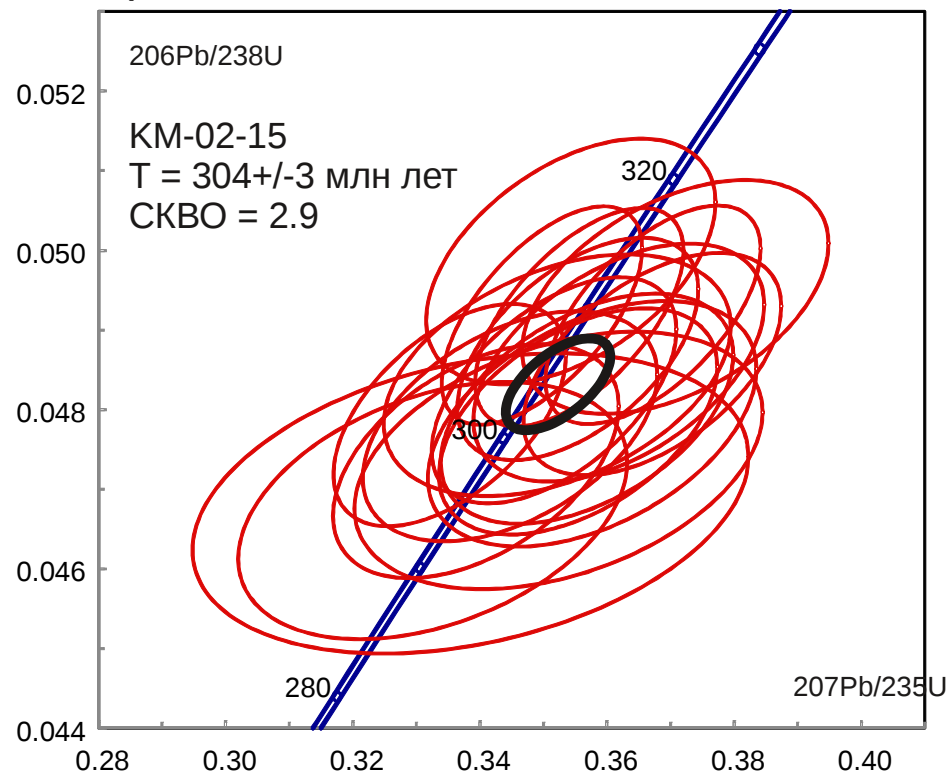

б)

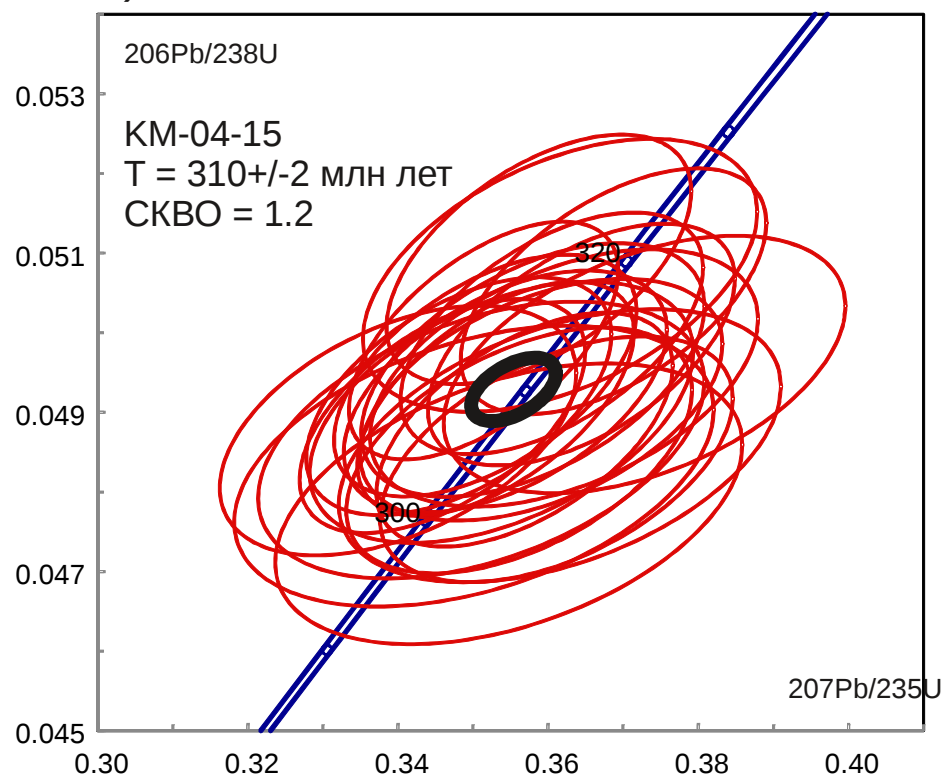

206Pb/238U

возраст

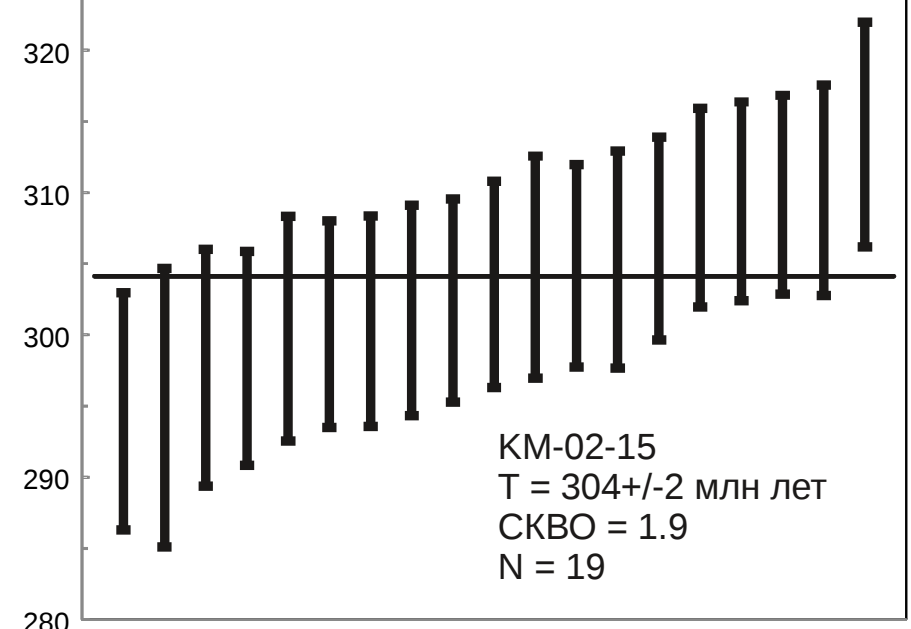

280

$335206 \mathrm{~Pb} / 238 \mathrm{U}$

возраст

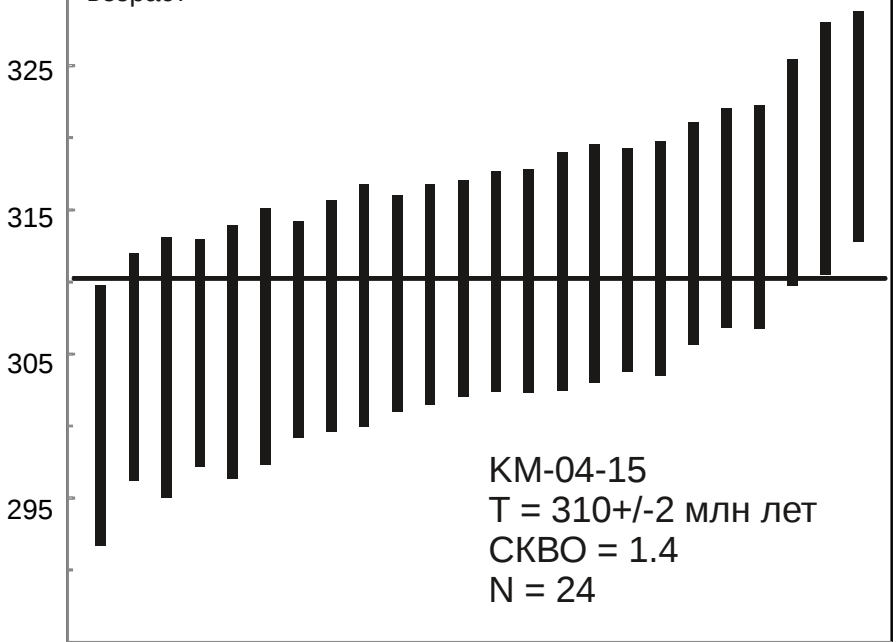


B)

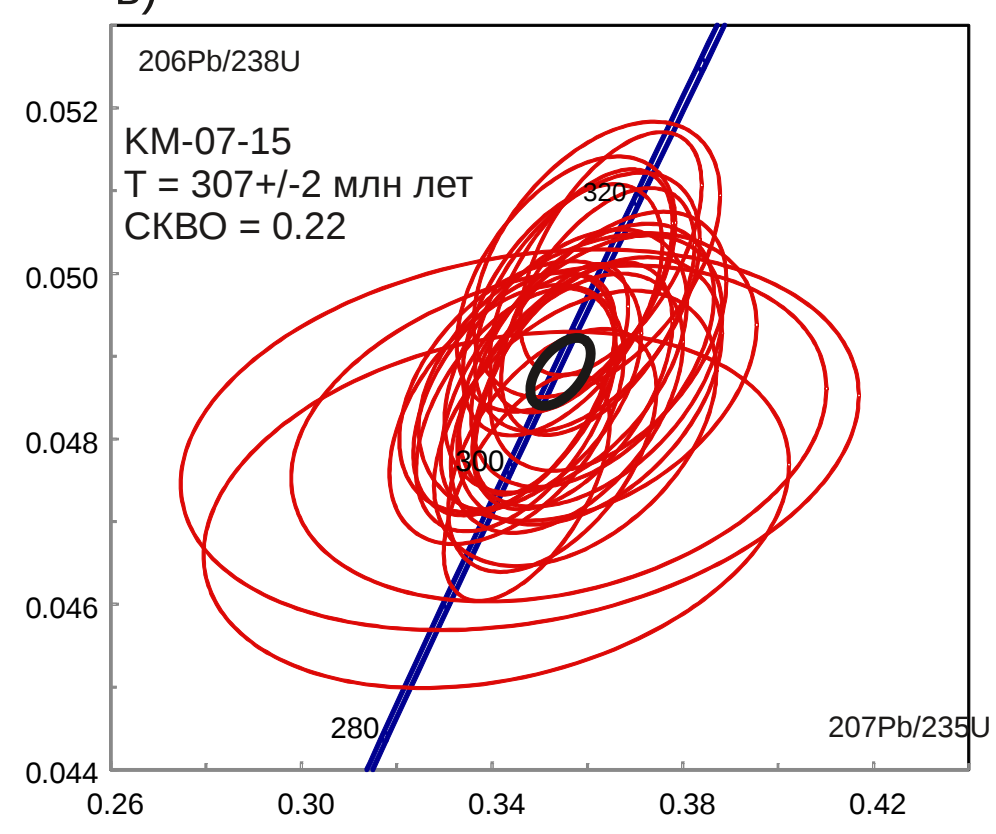

г)

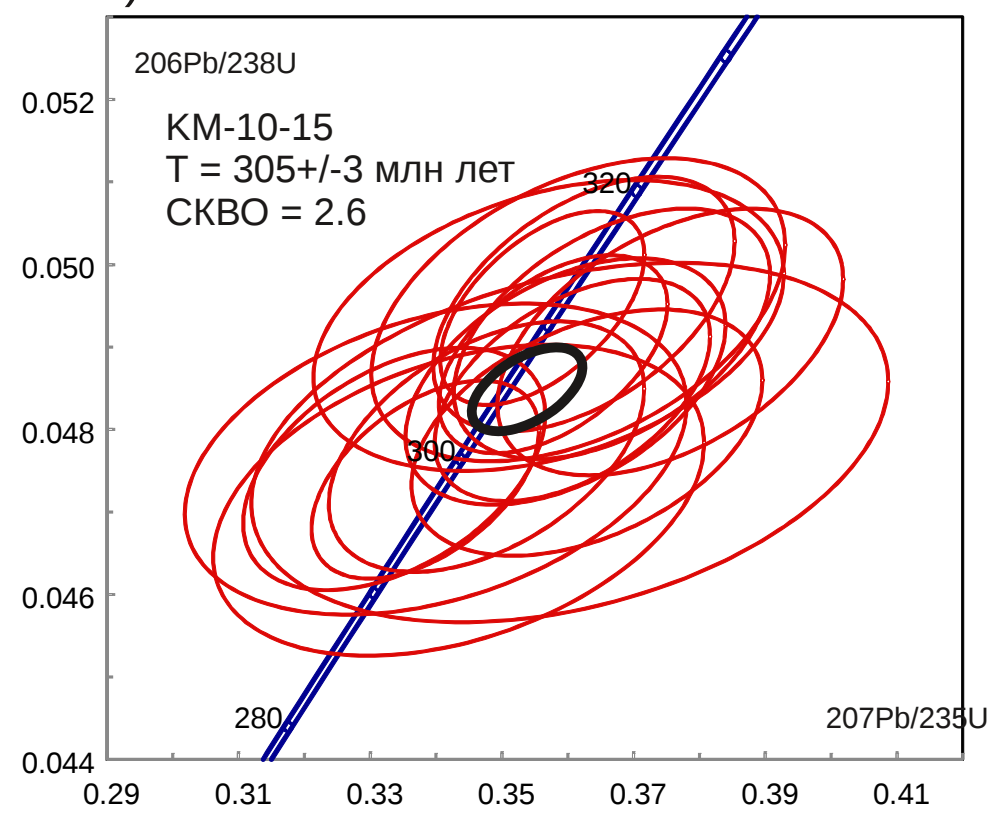

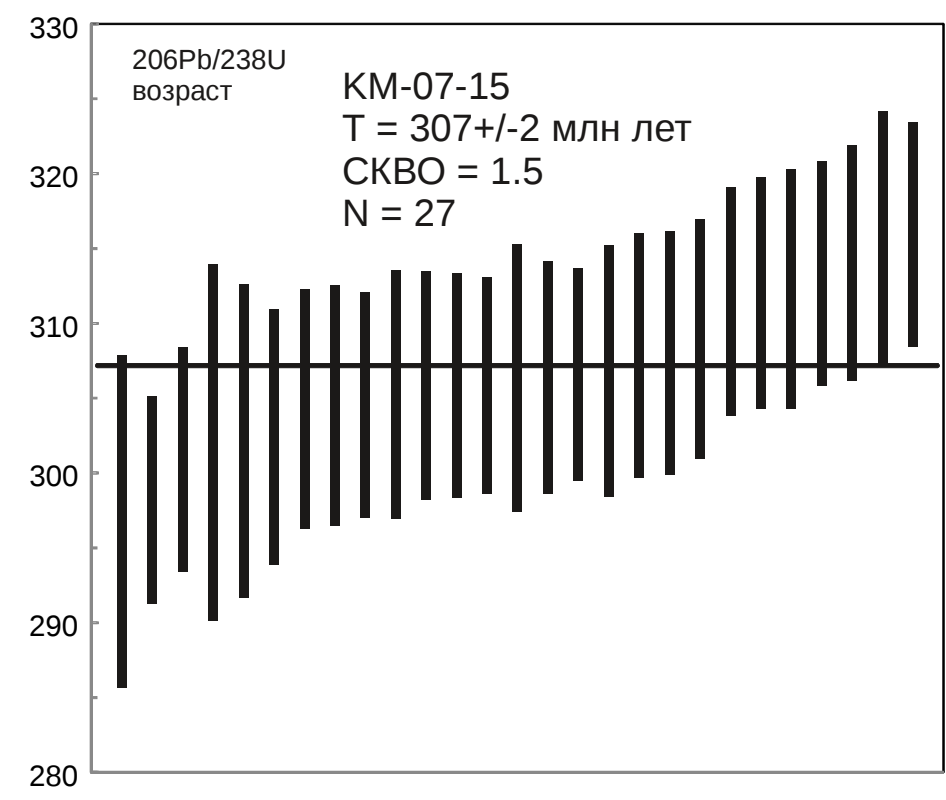

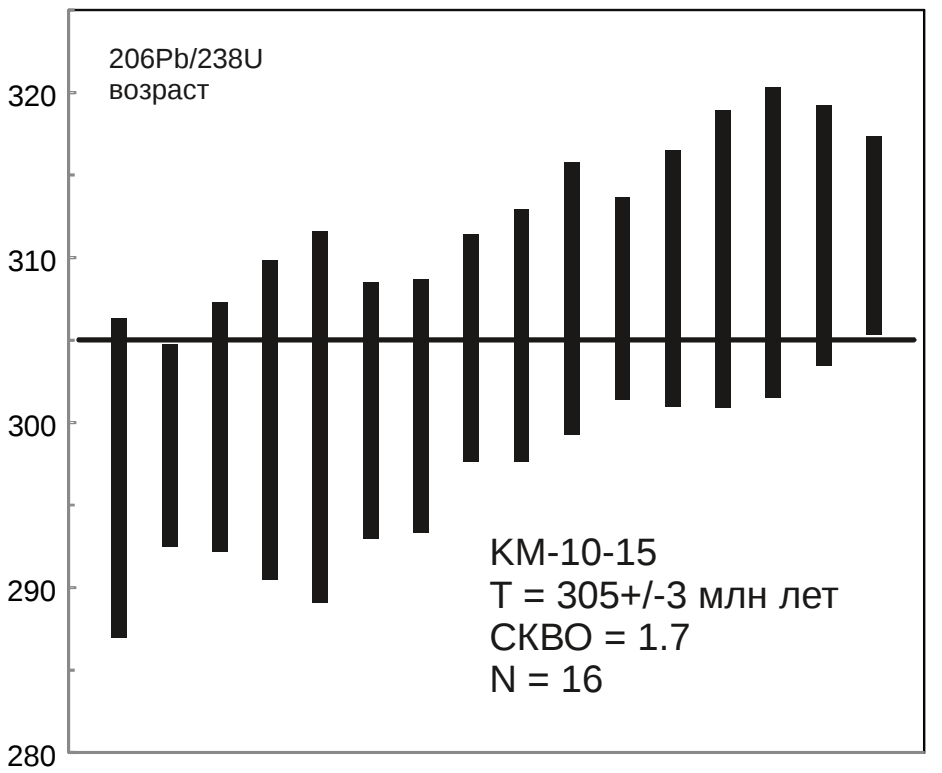


a)
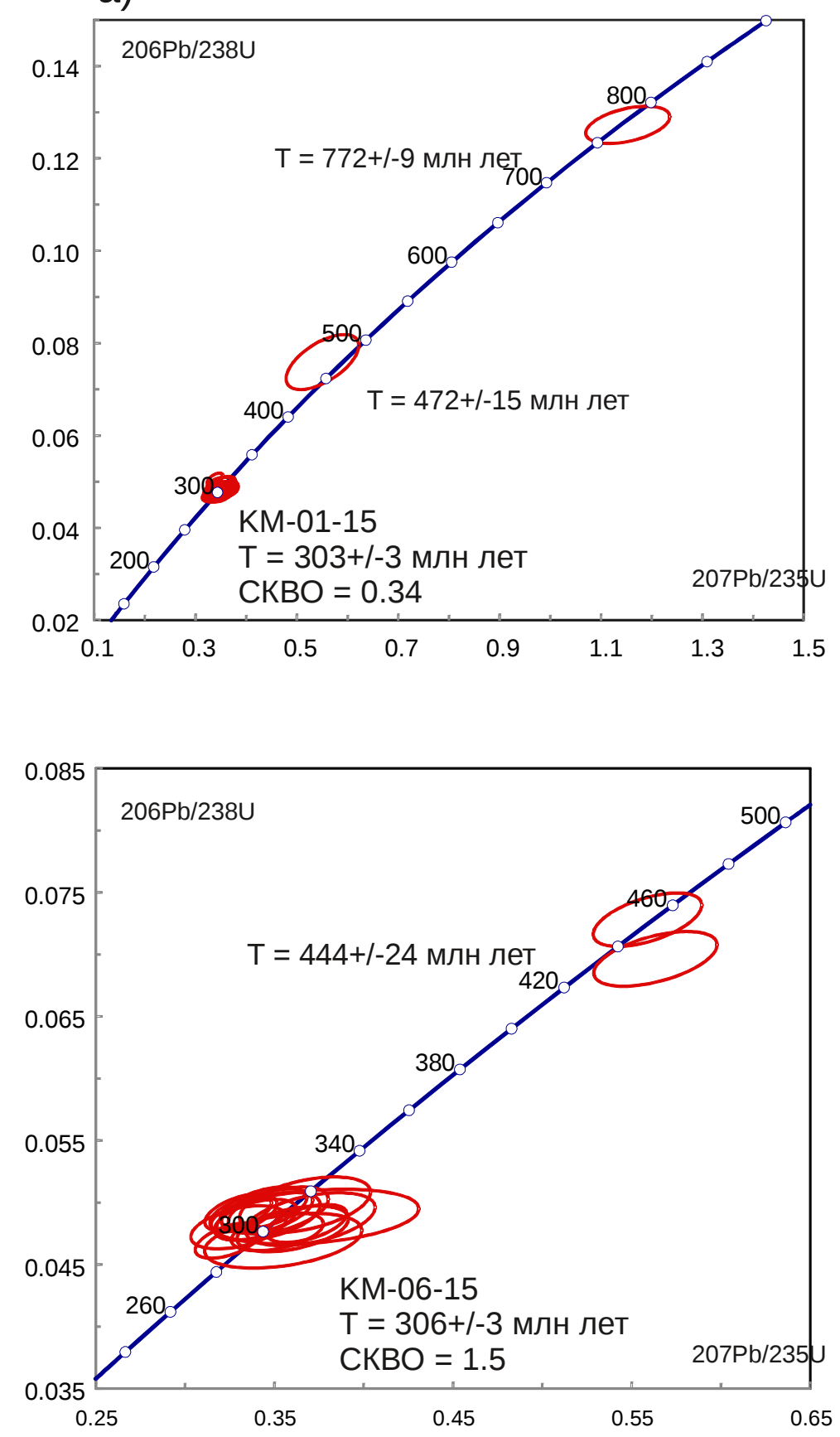
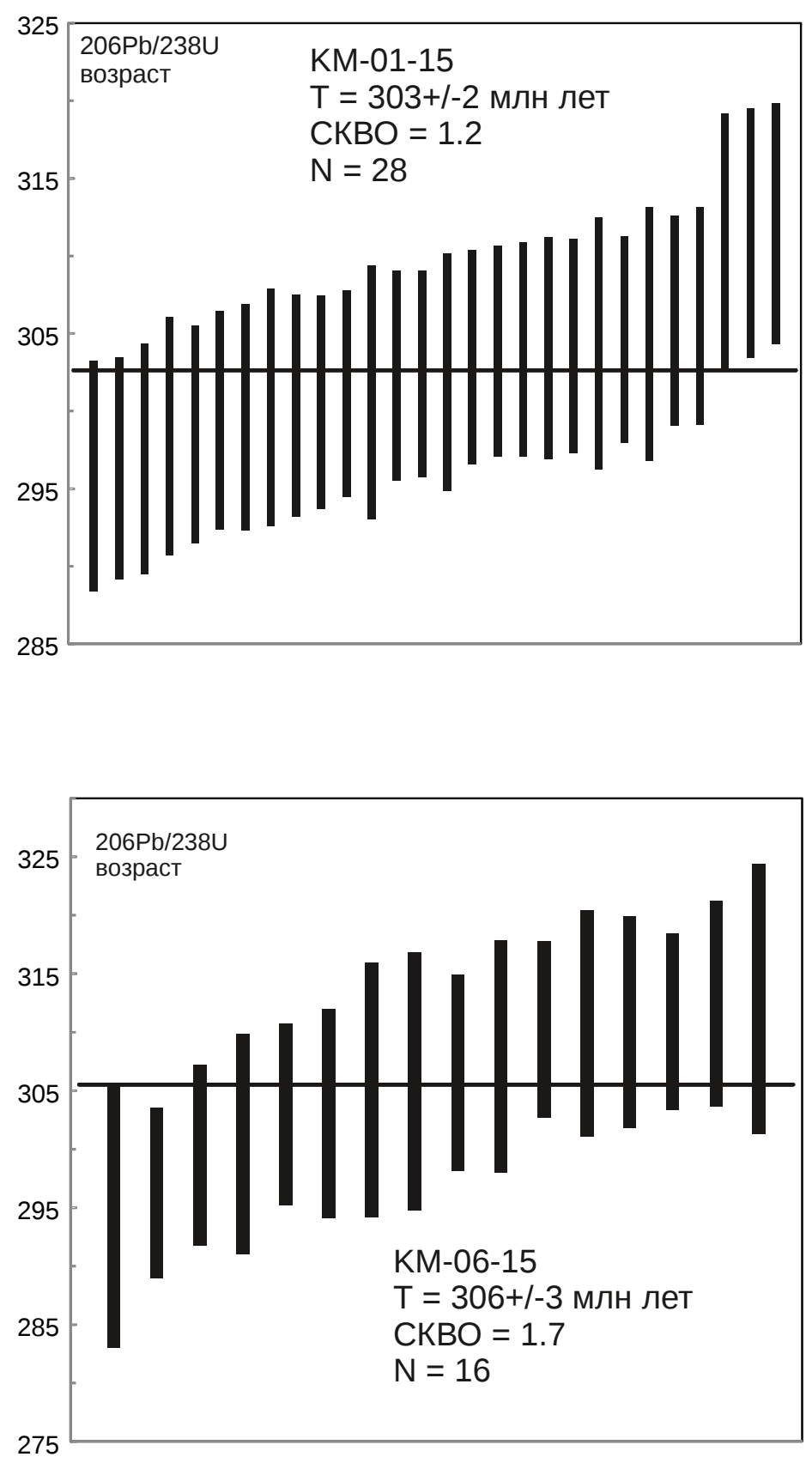
a)

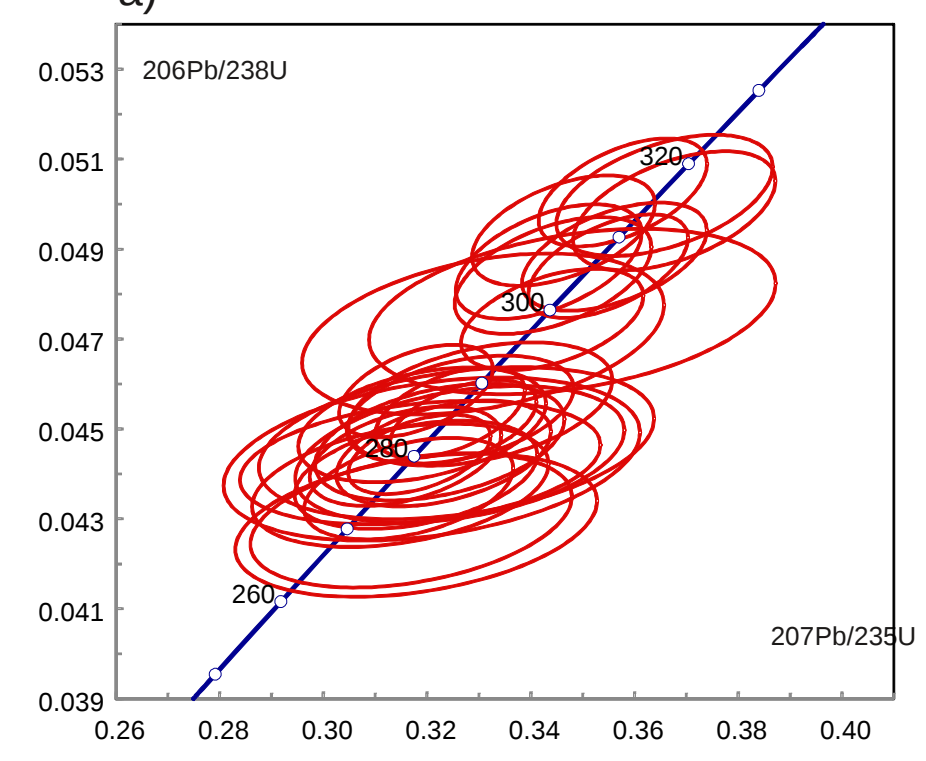

б)

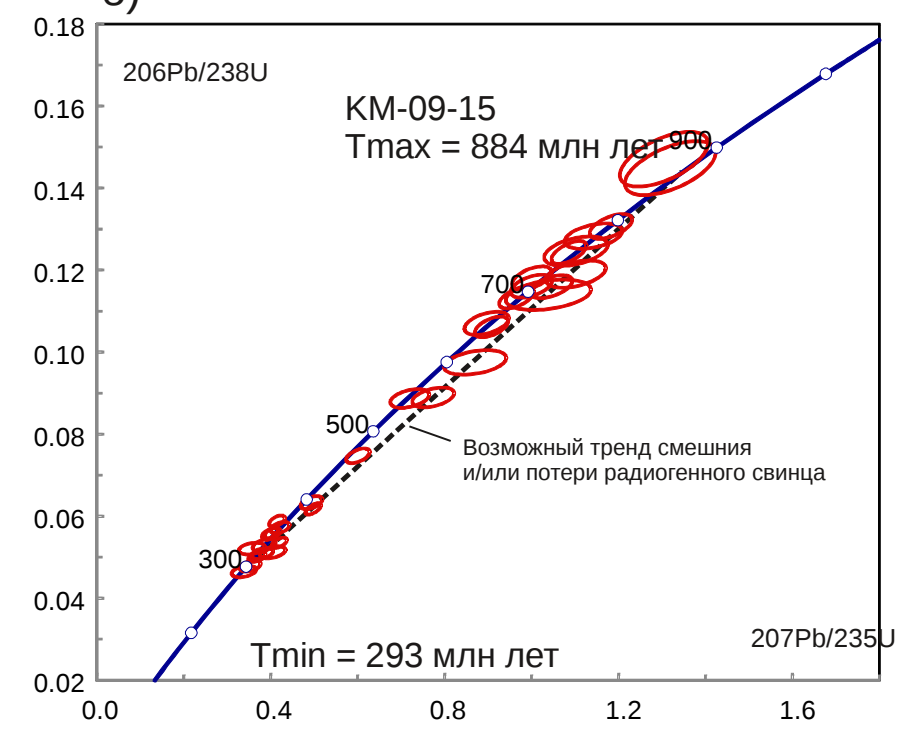

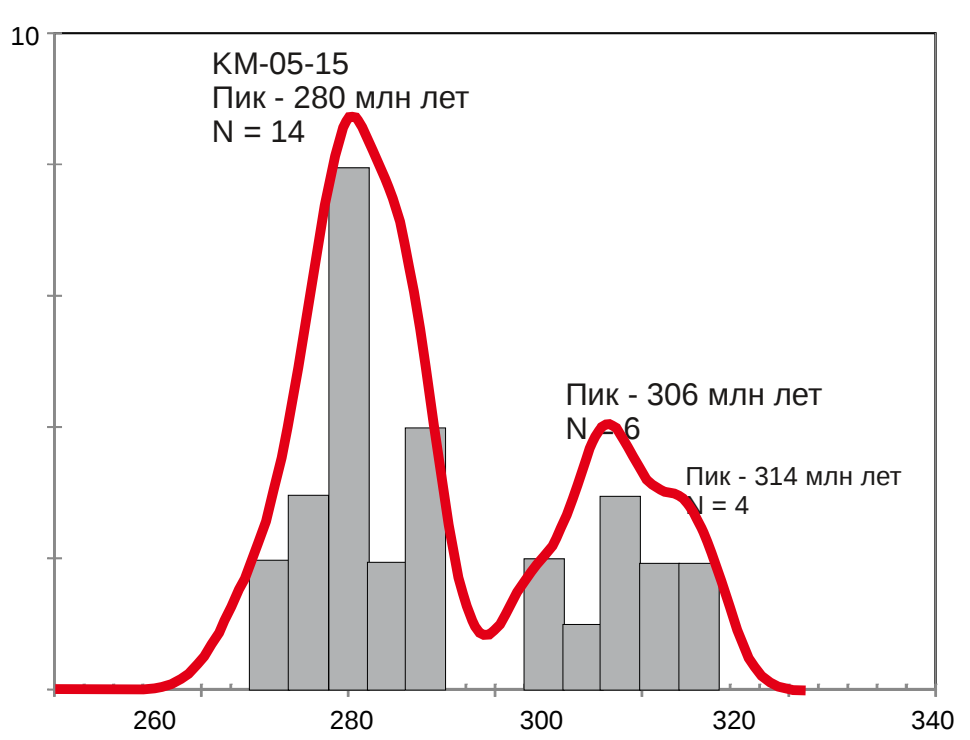

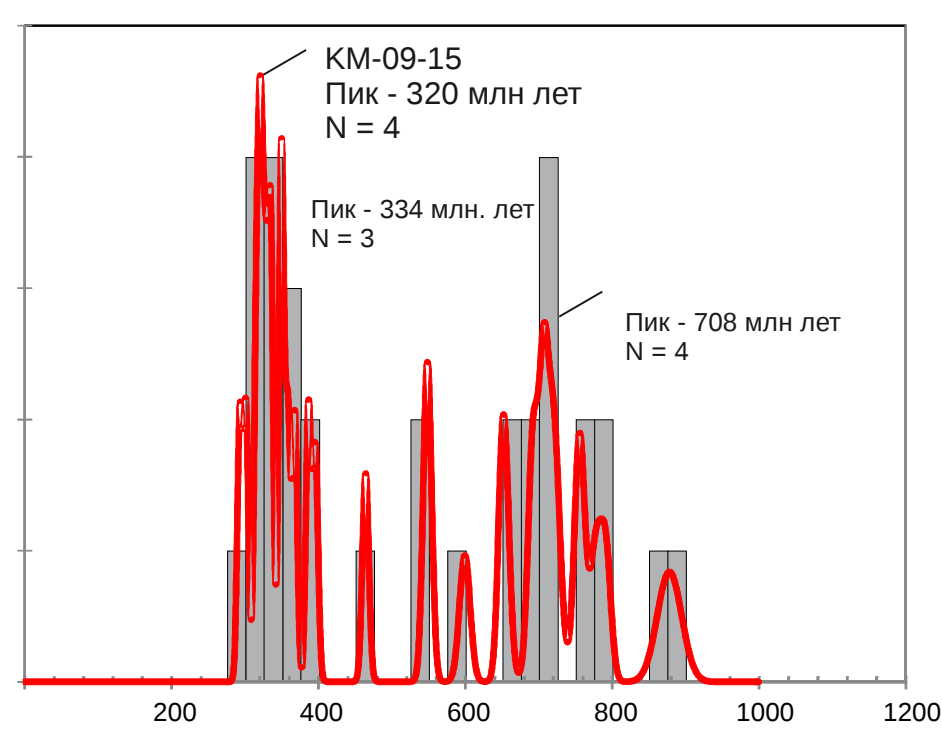




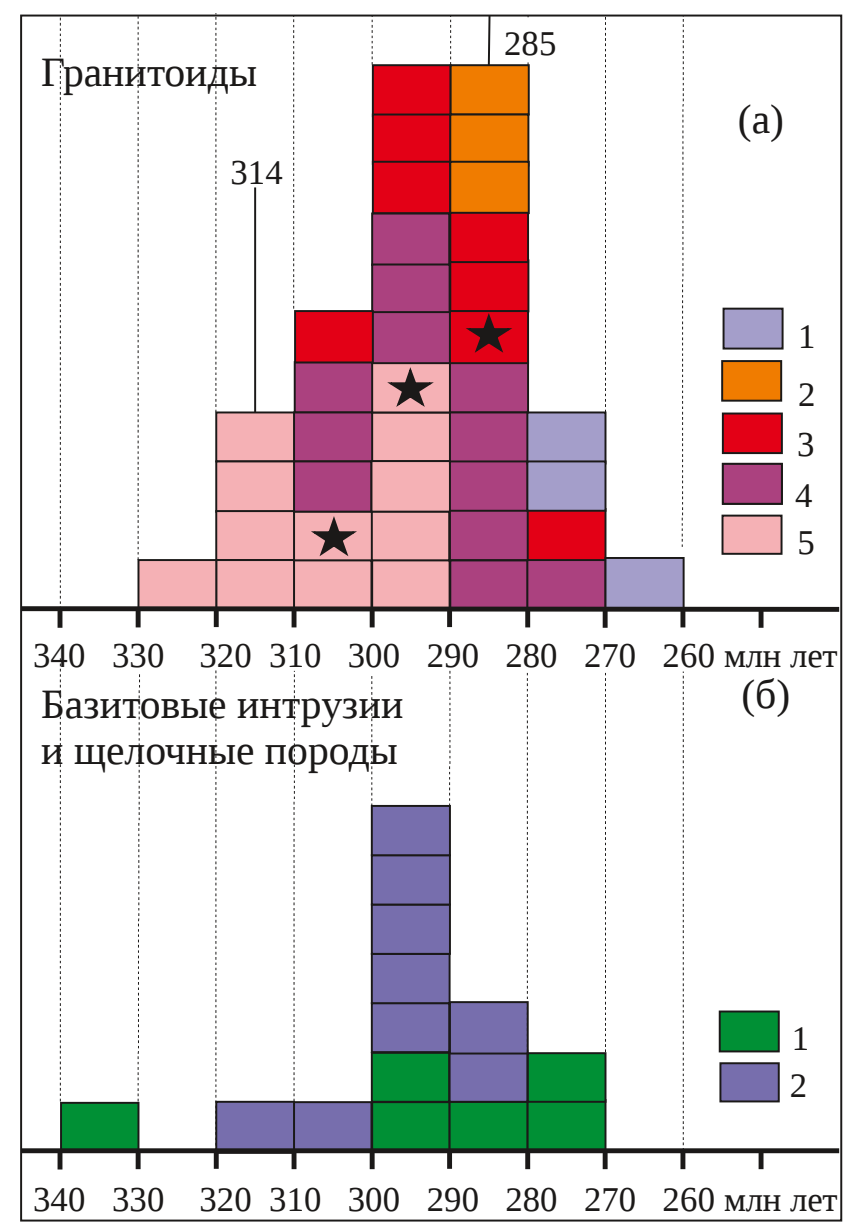


а) Поздний карбон
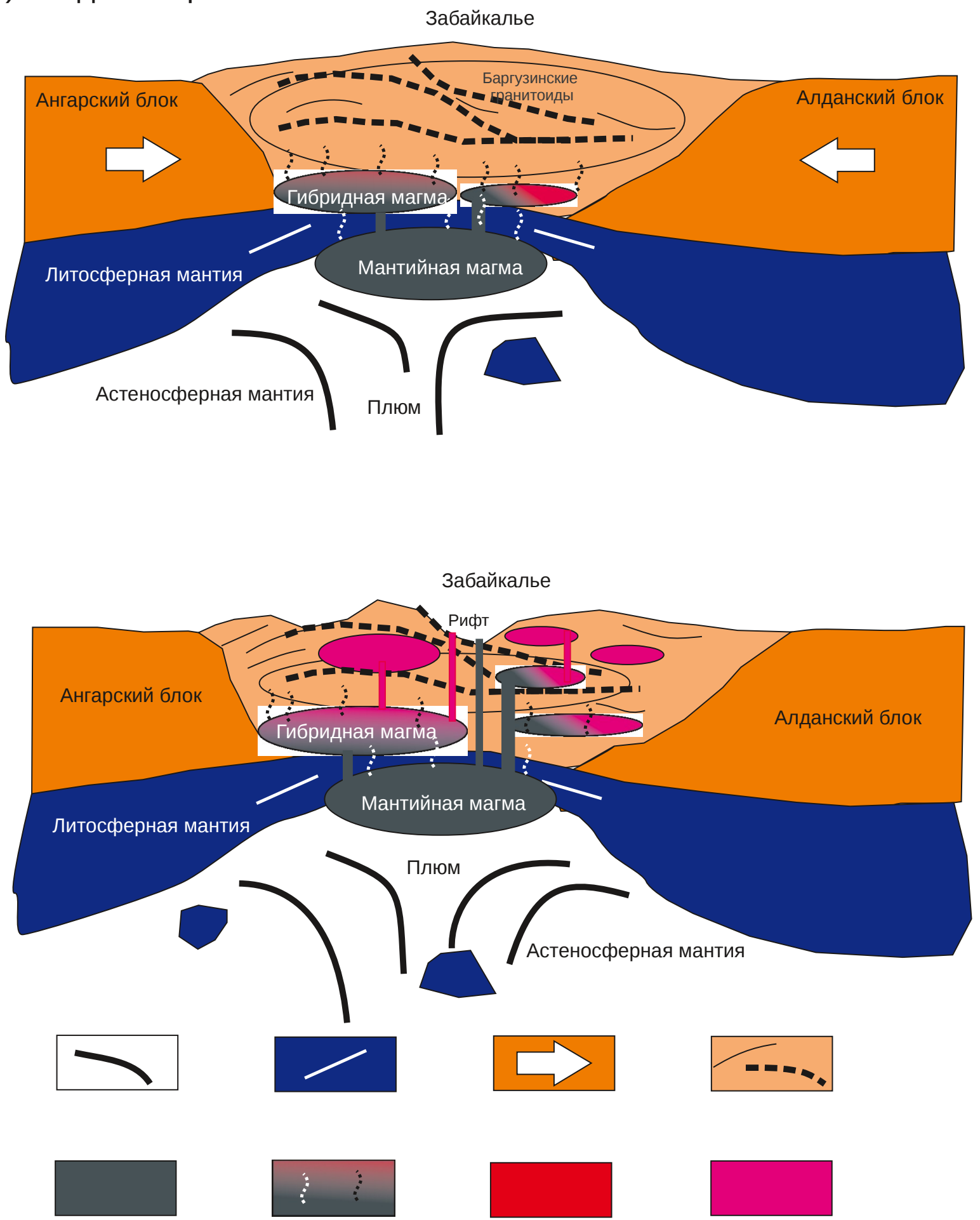


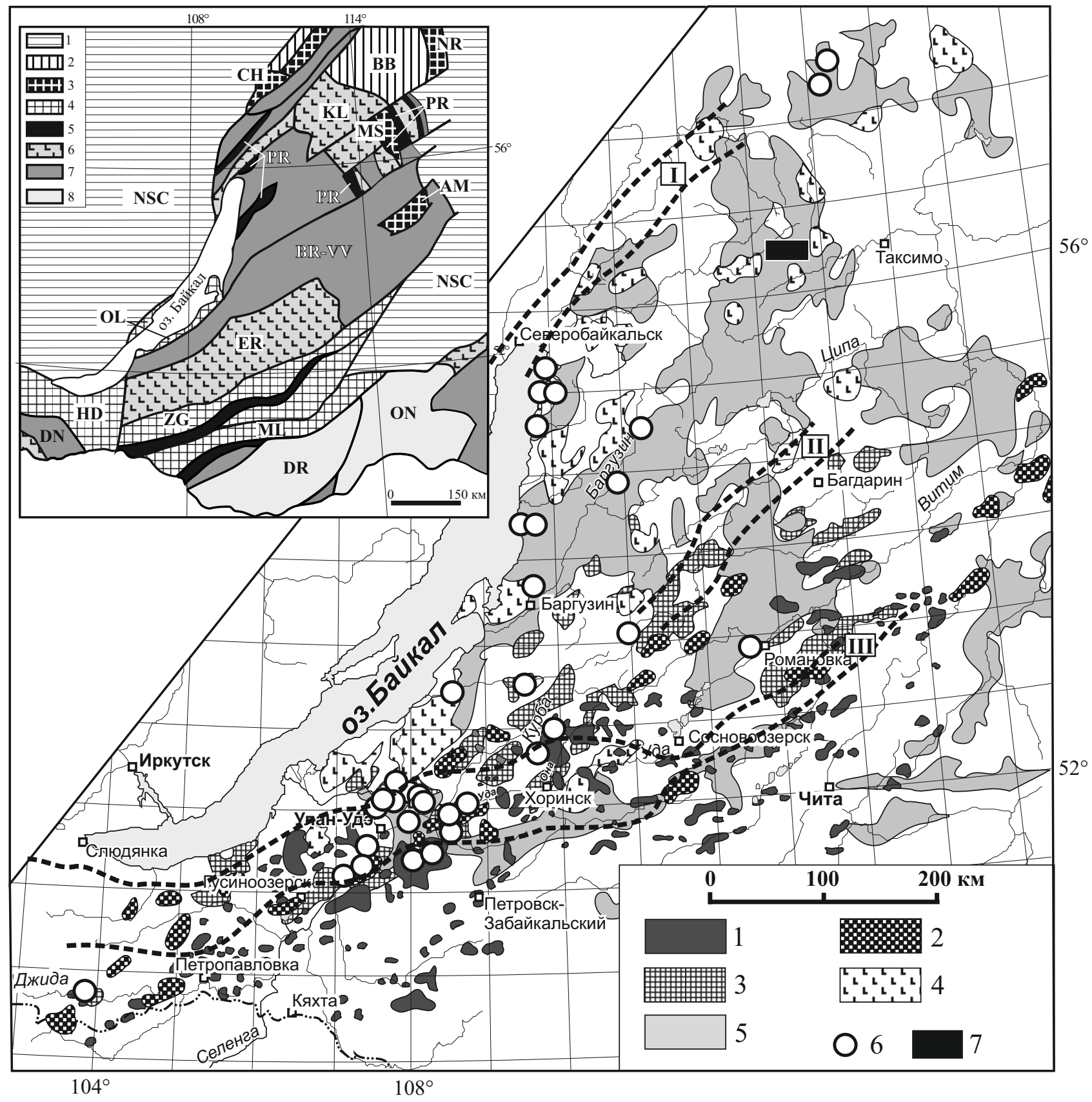




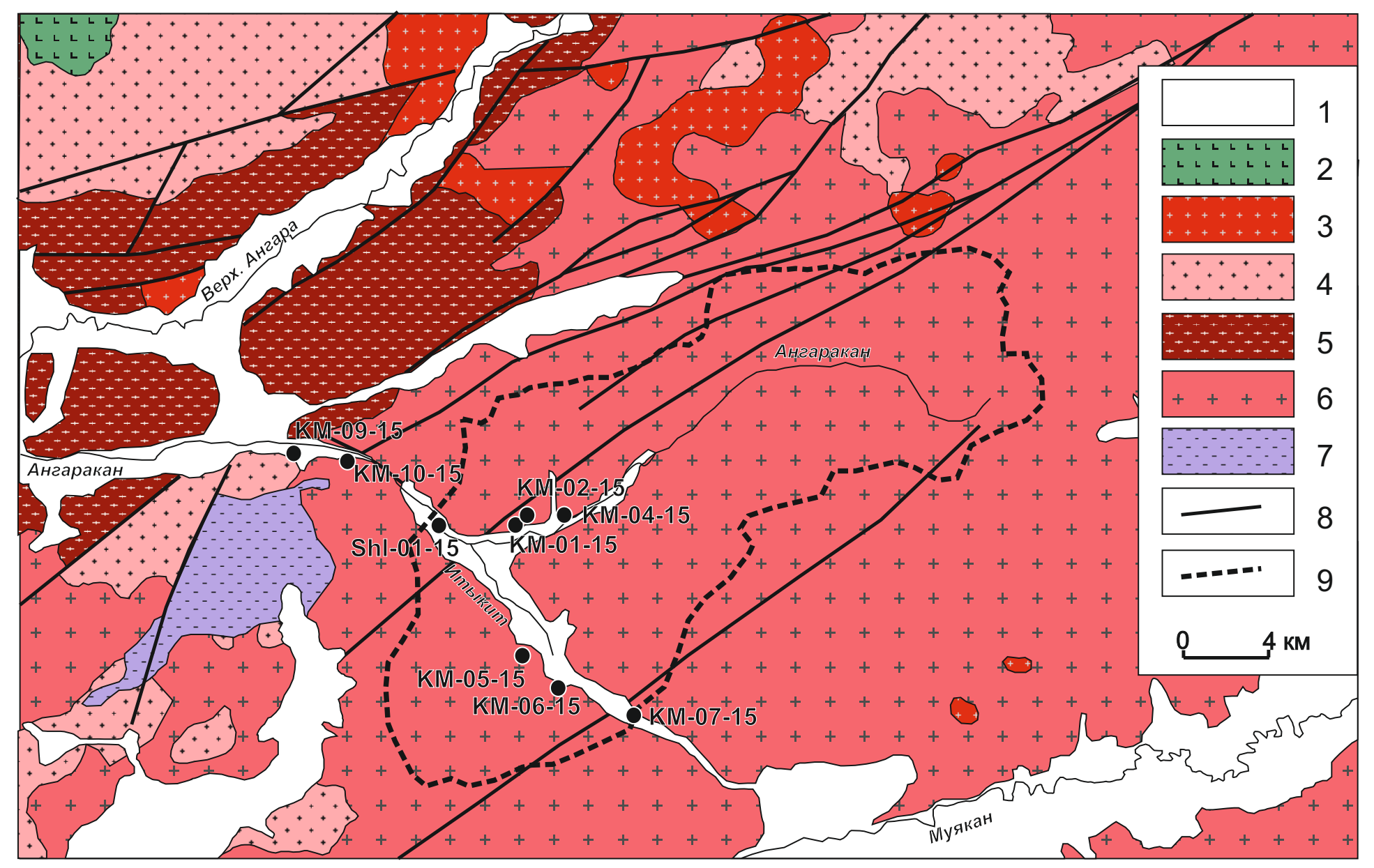



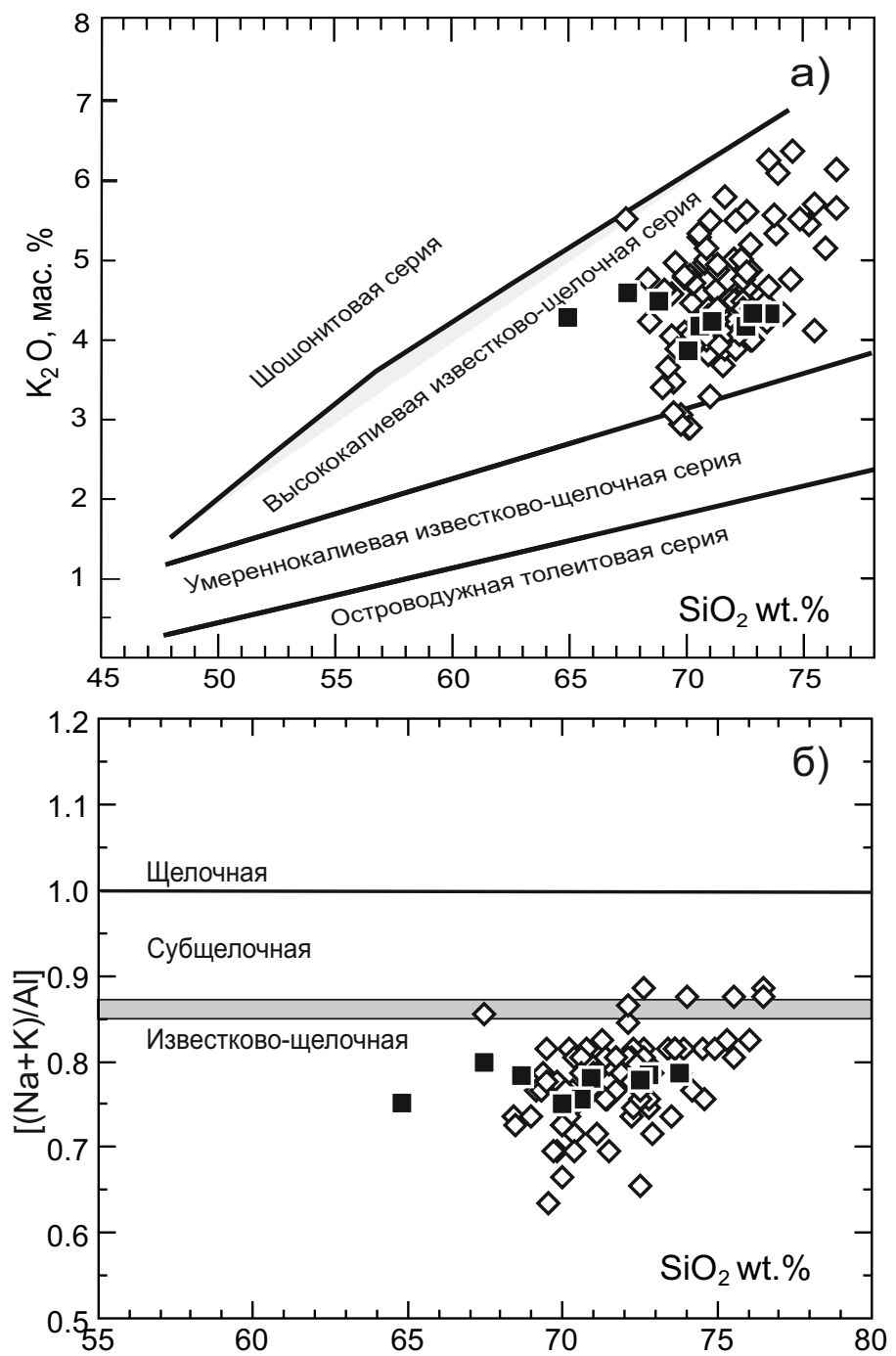
a)

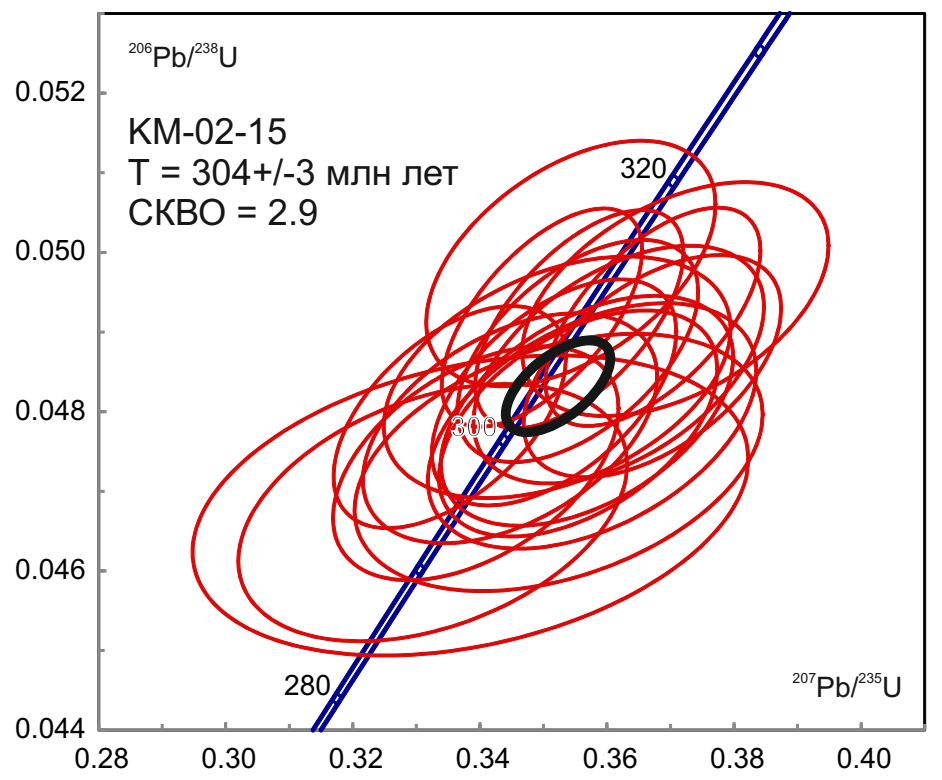

б)

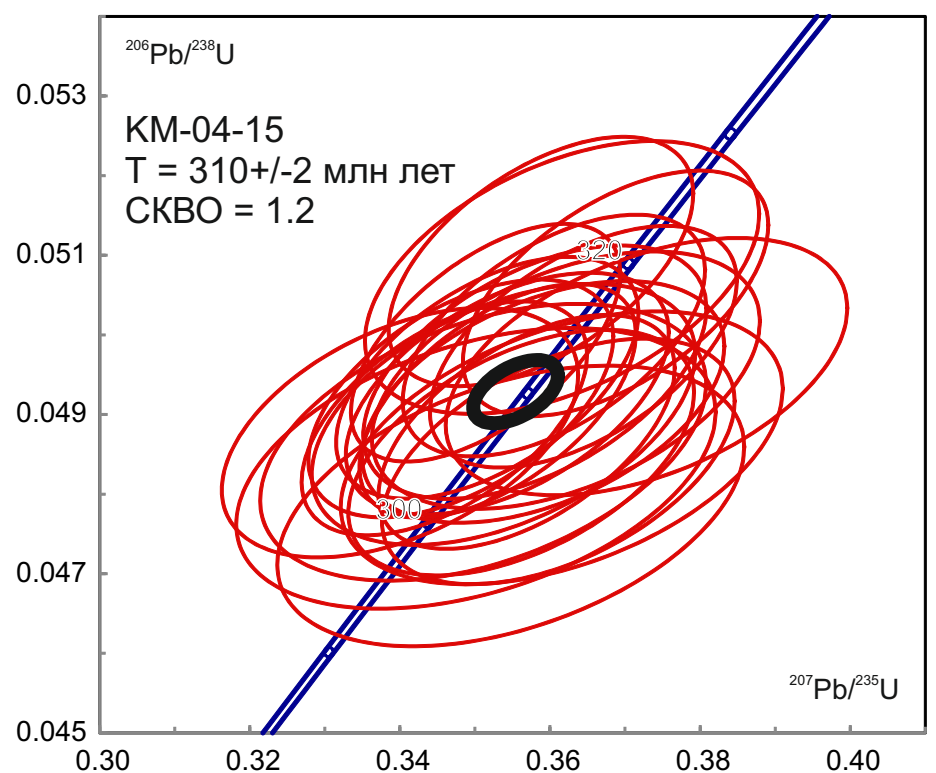

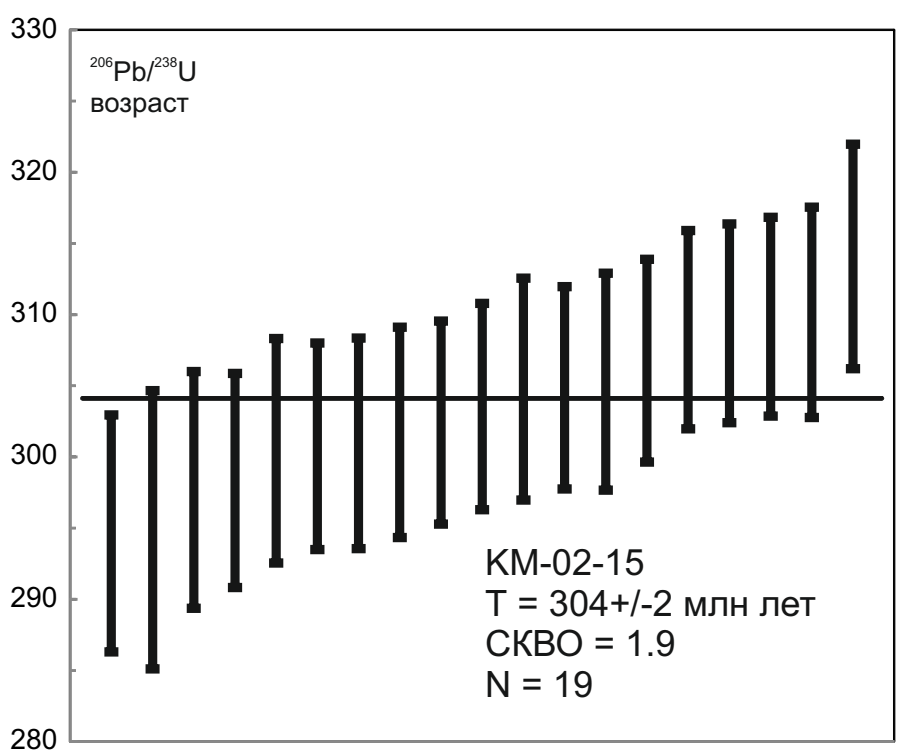

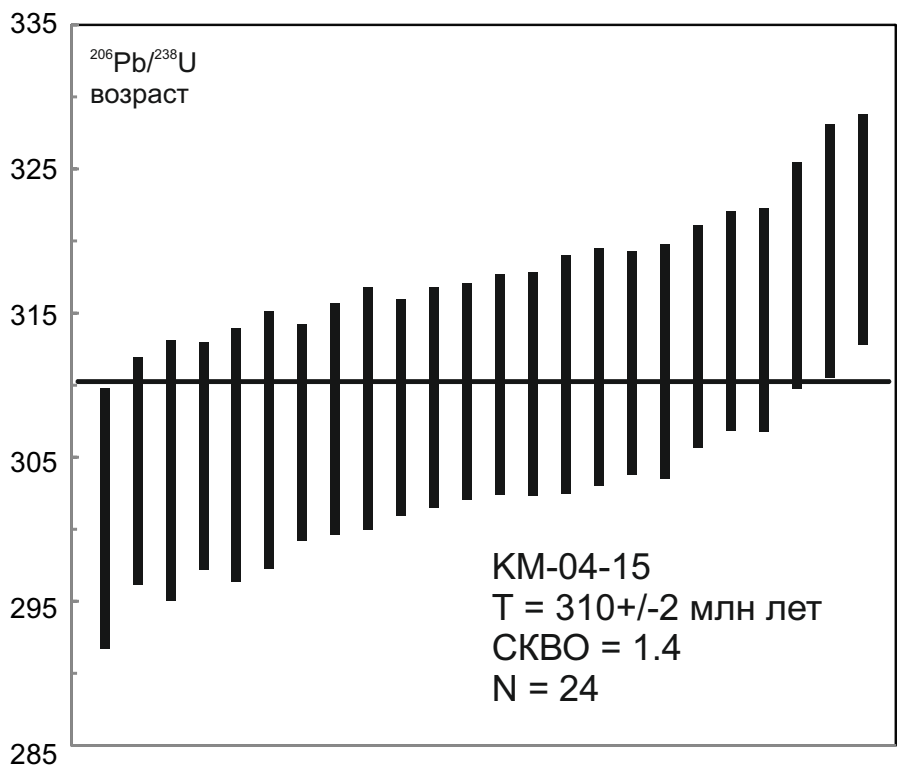


B)

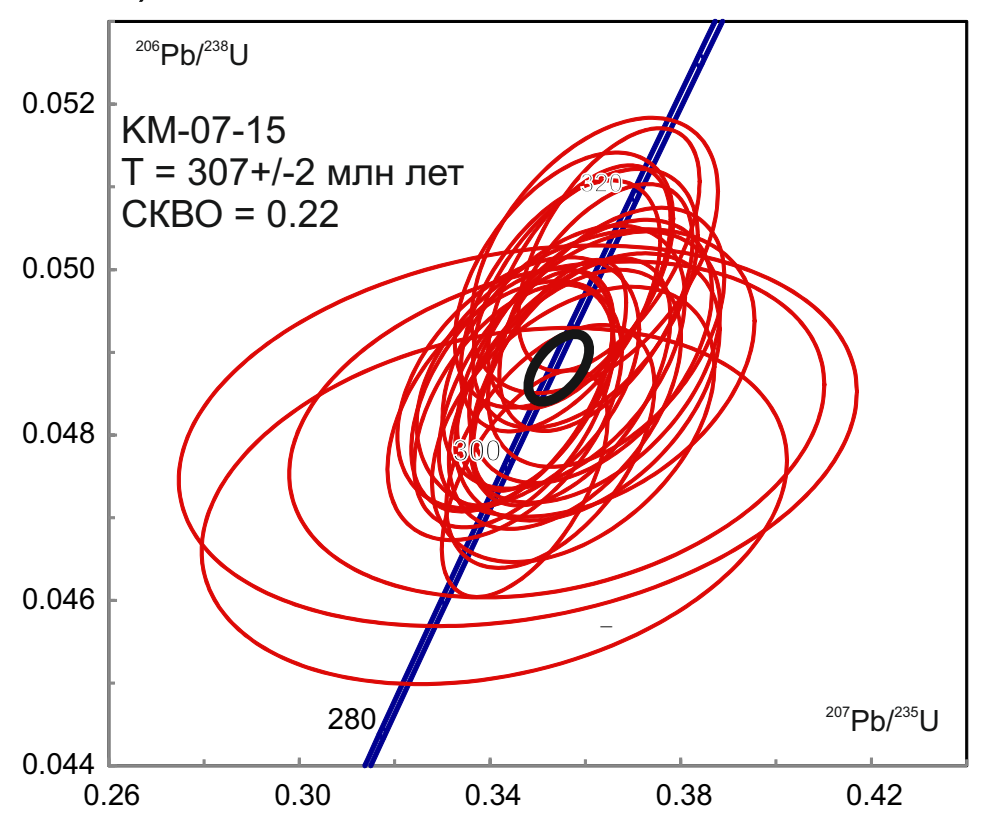

г)

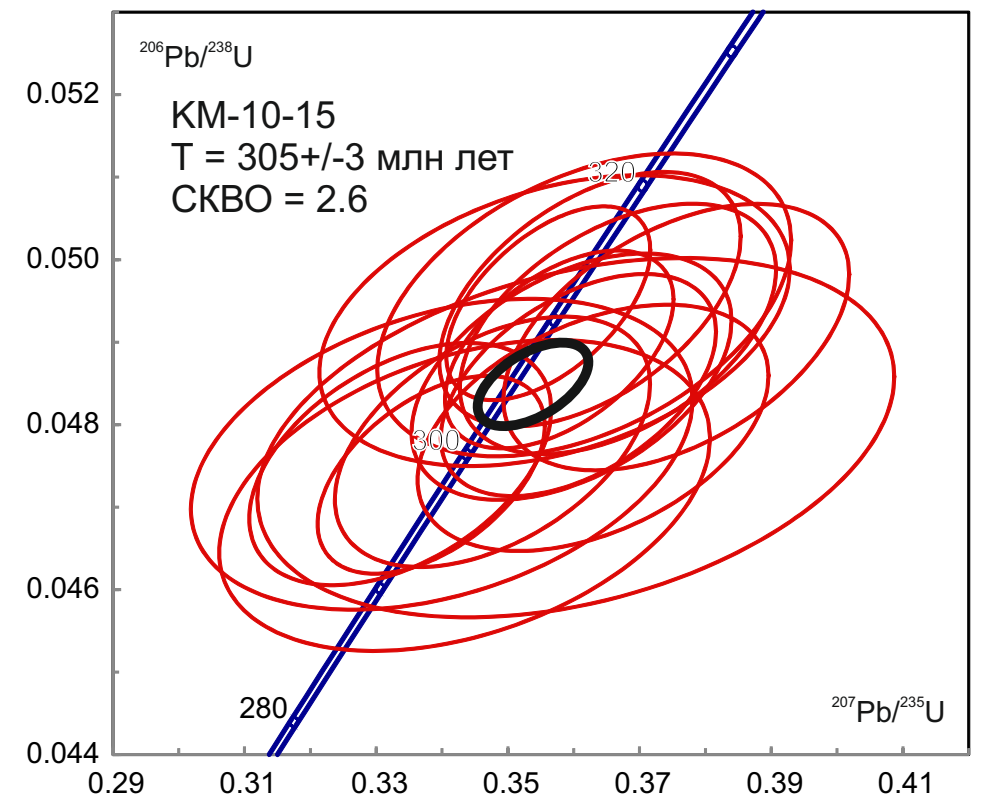

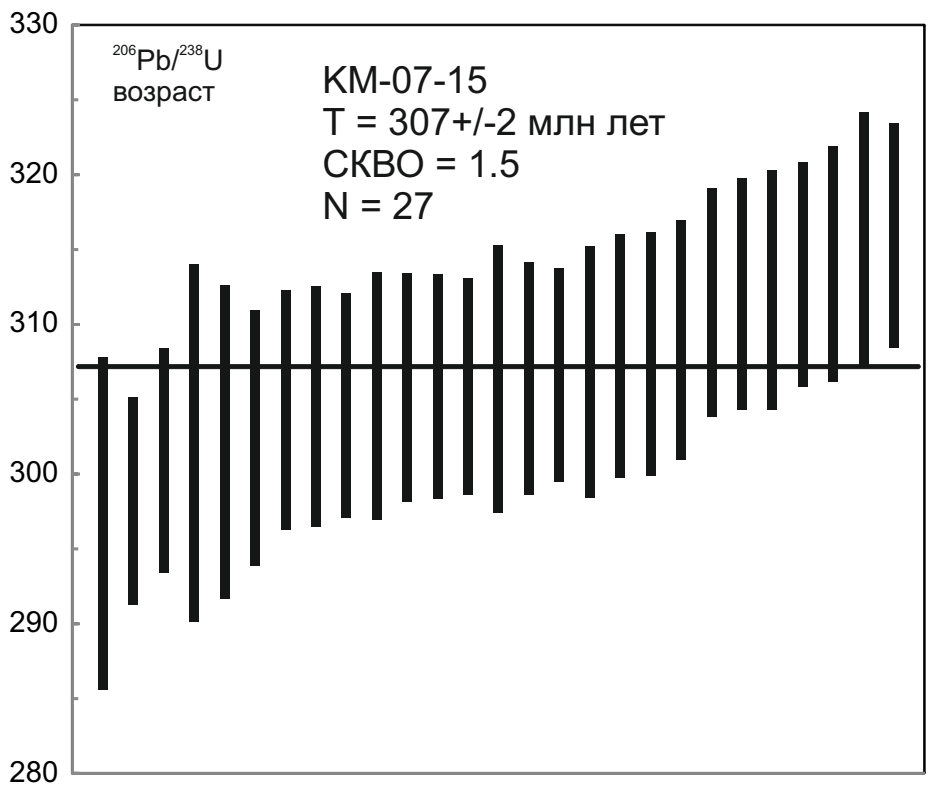

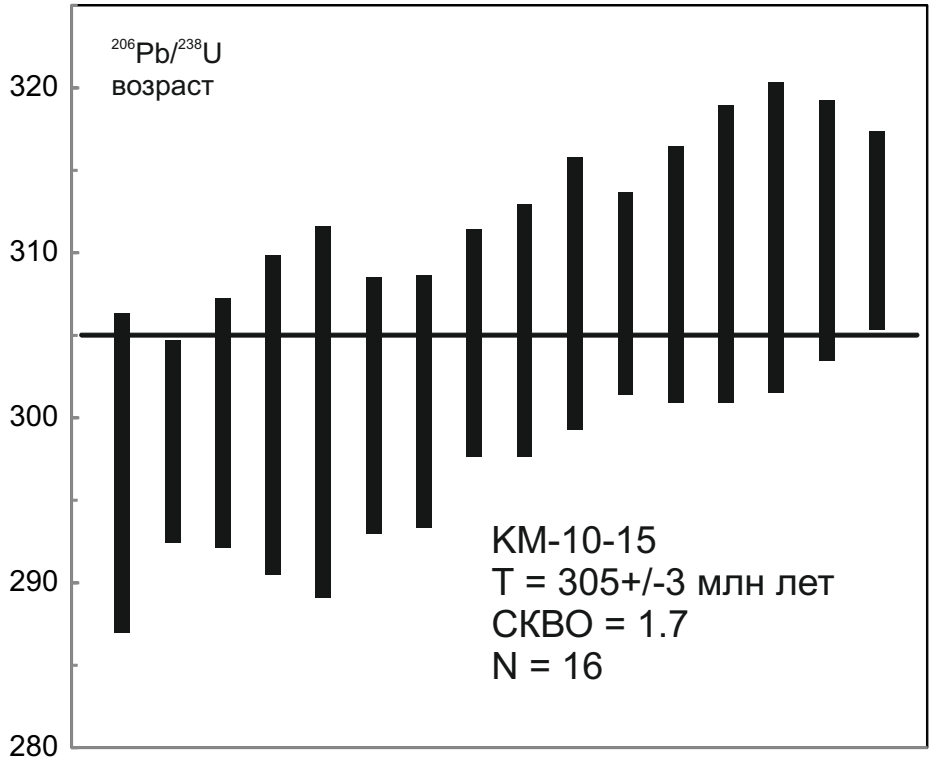


a)

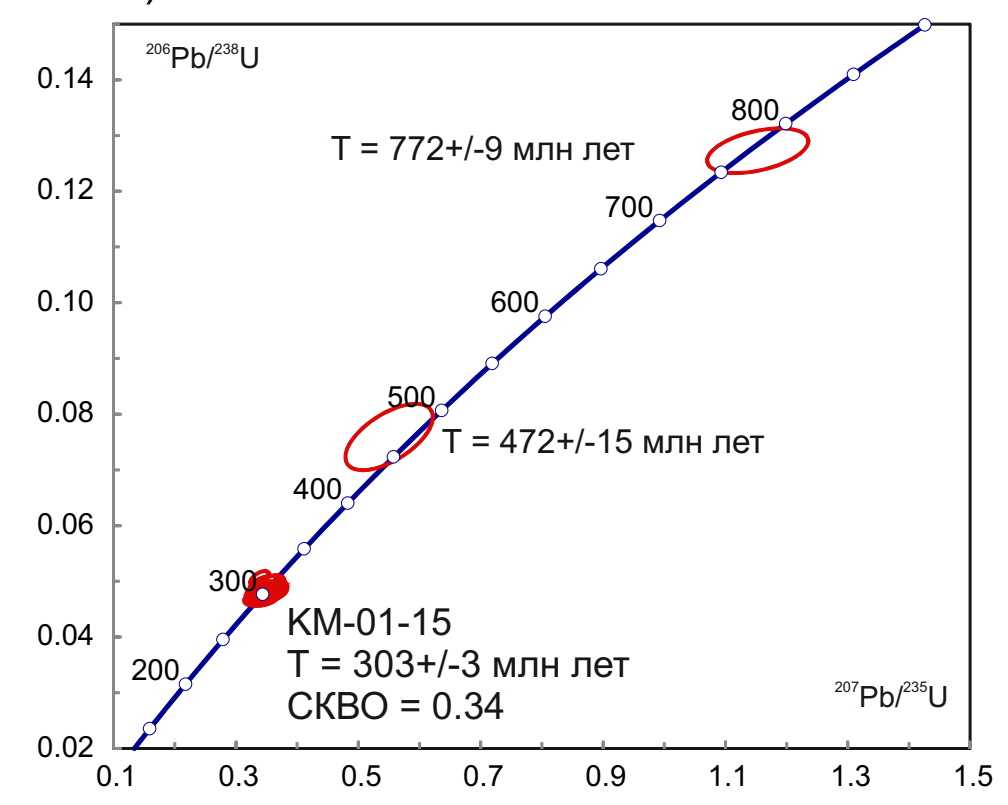

б)

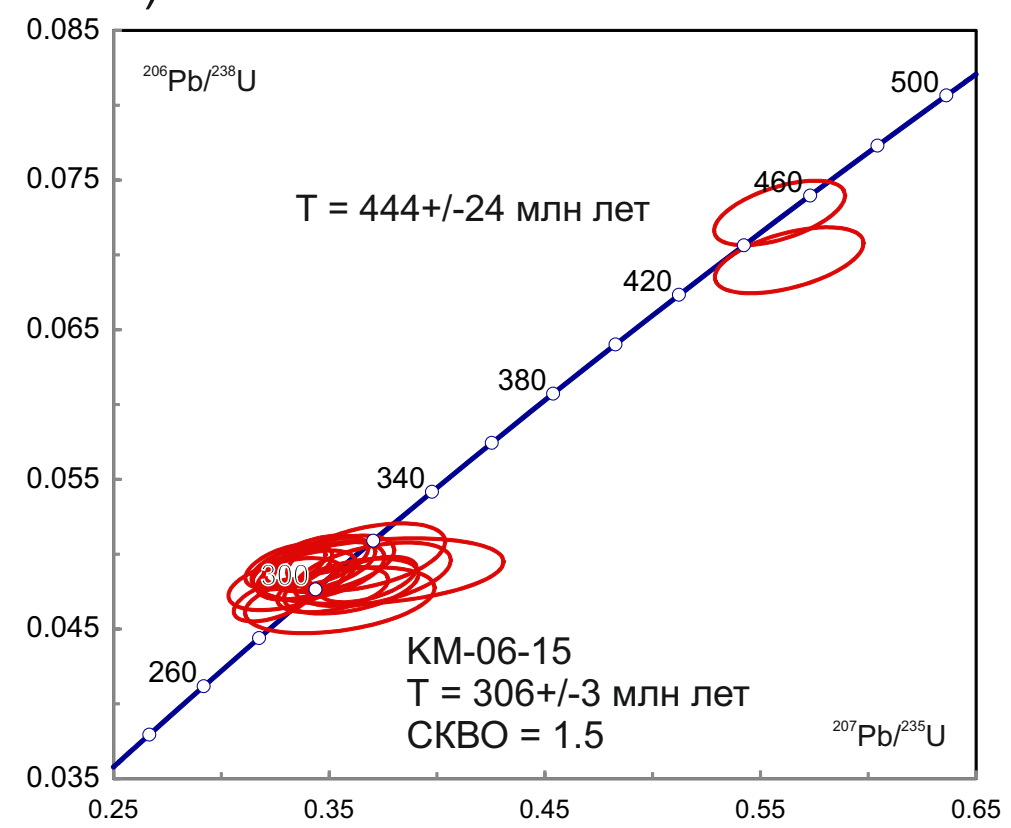

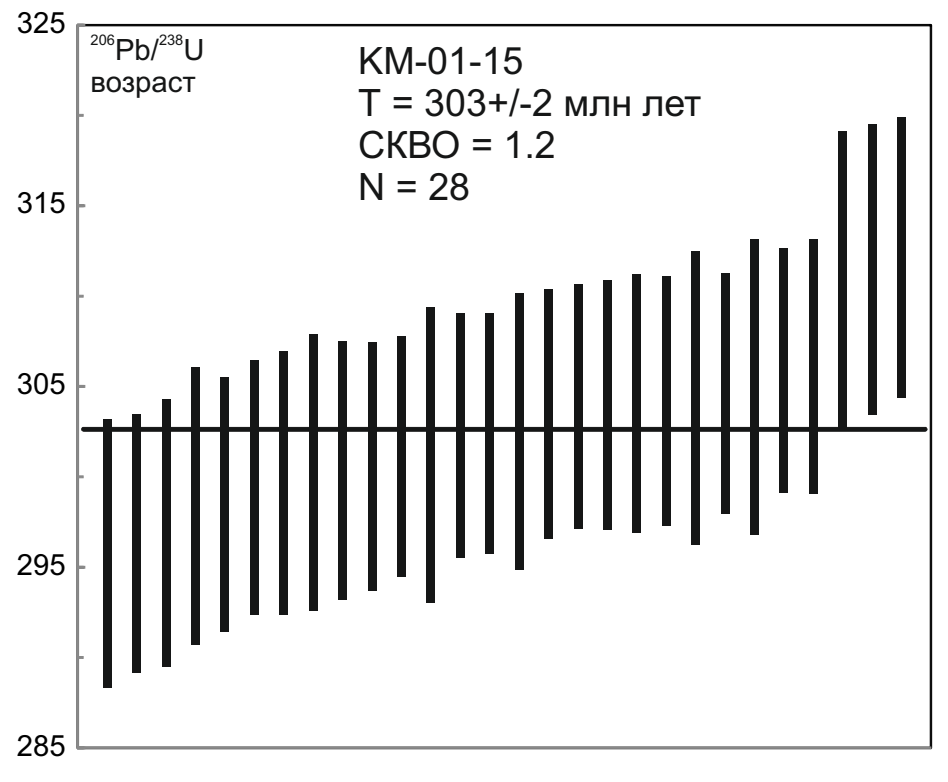

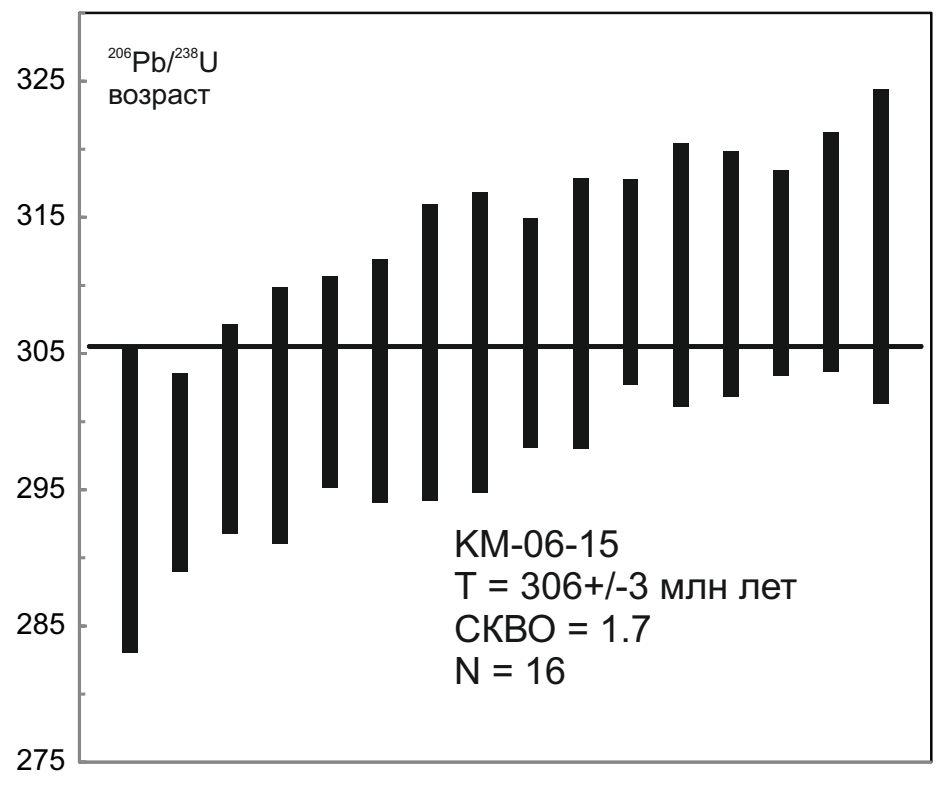


a)

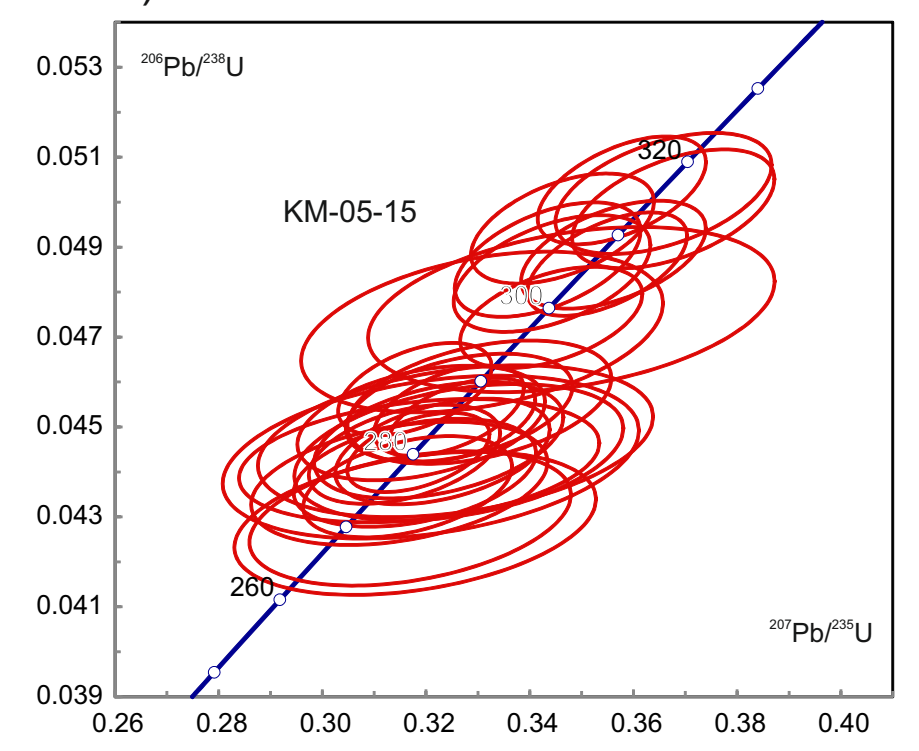

б)

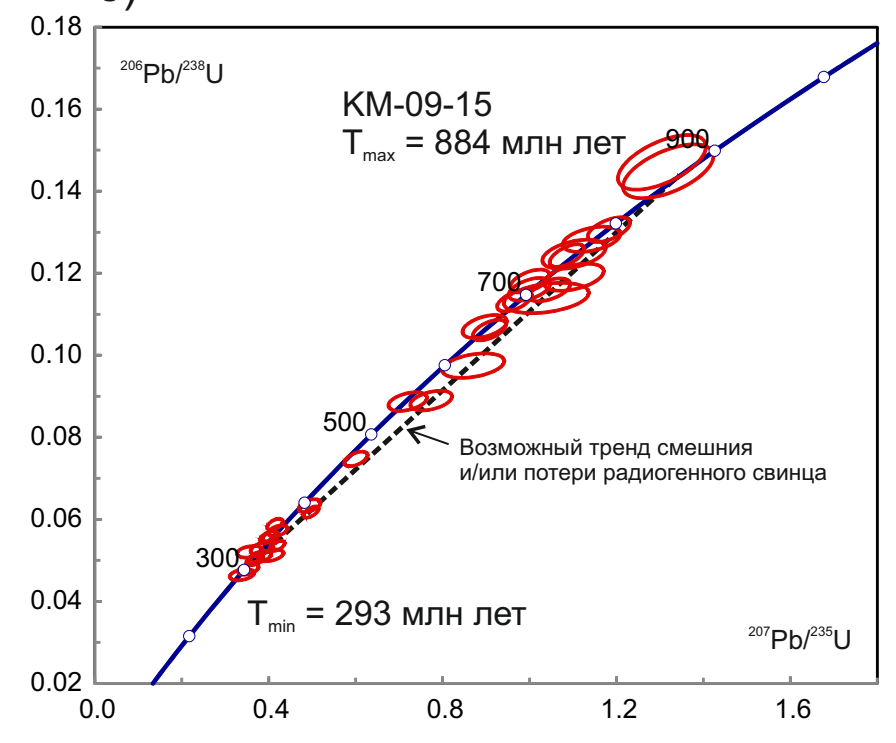

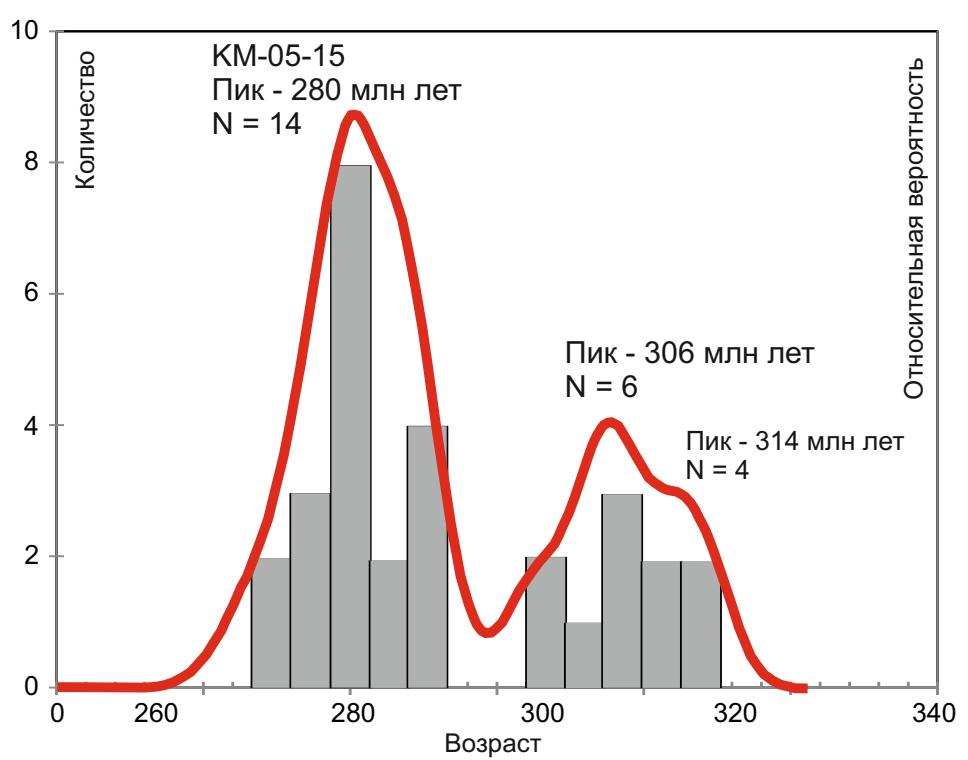

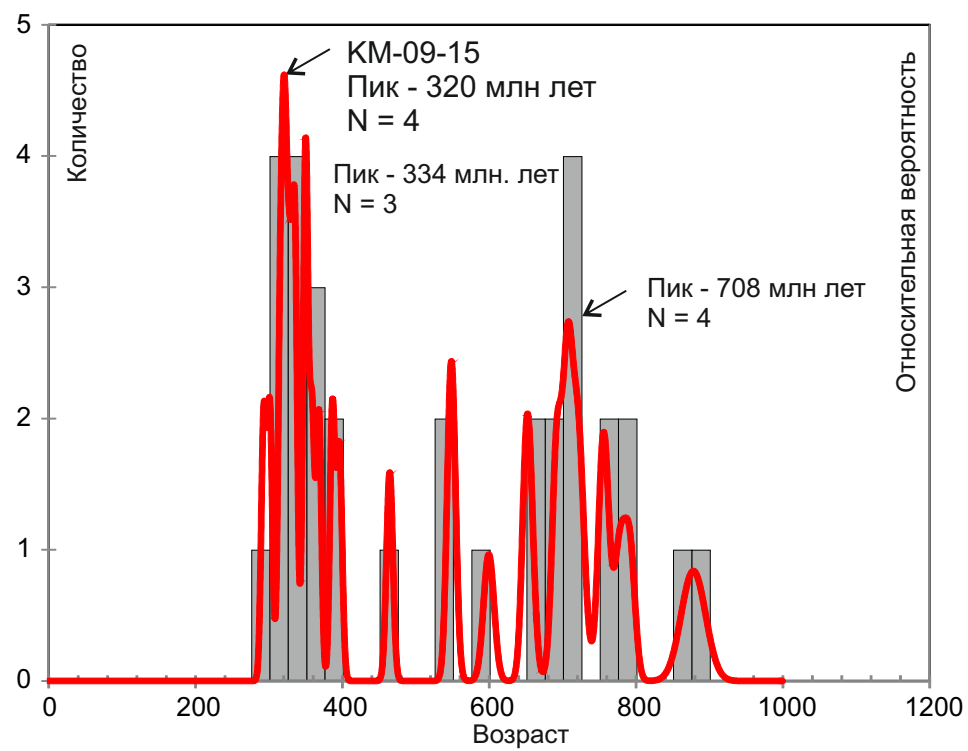


a)
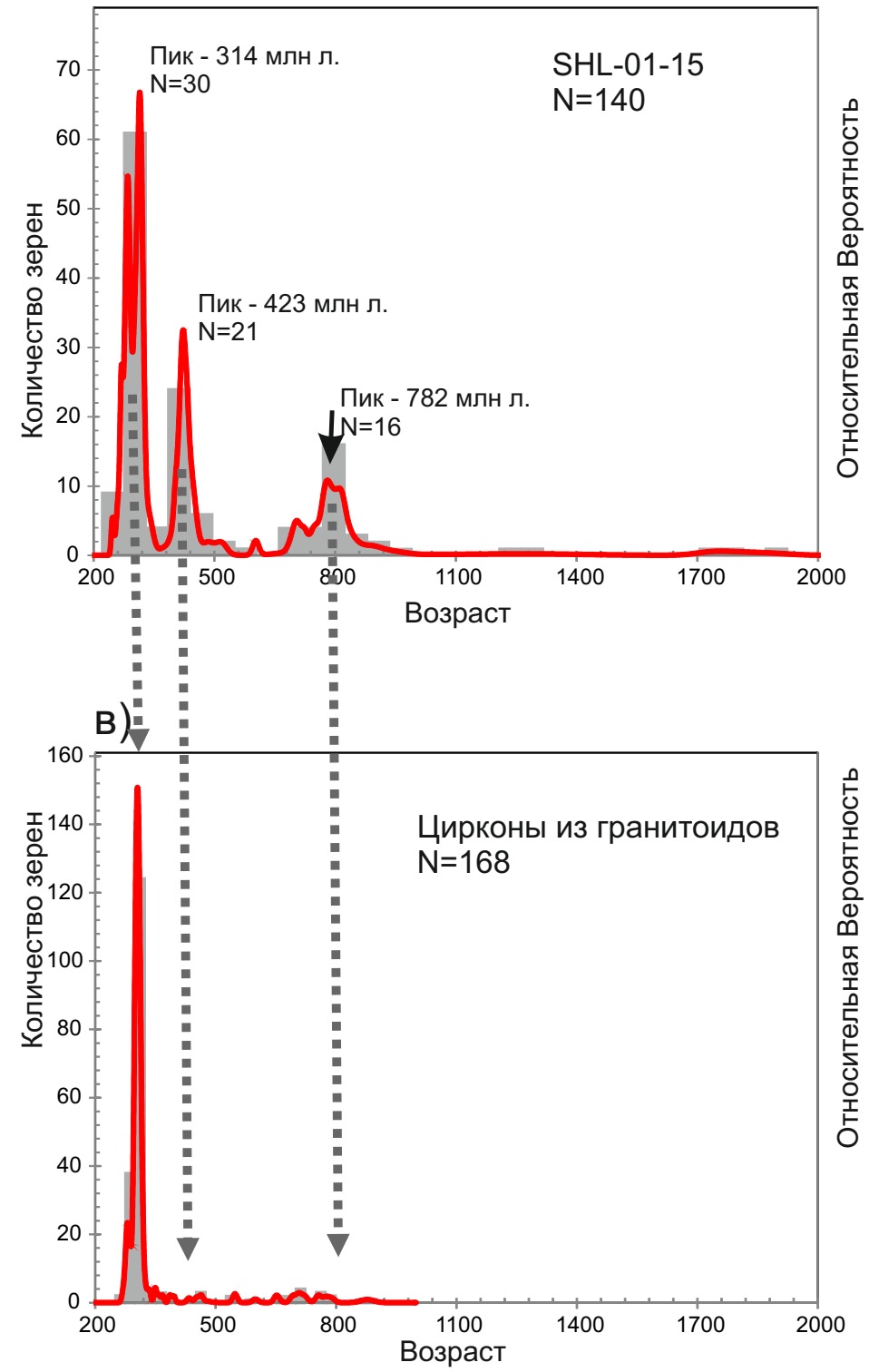

б)

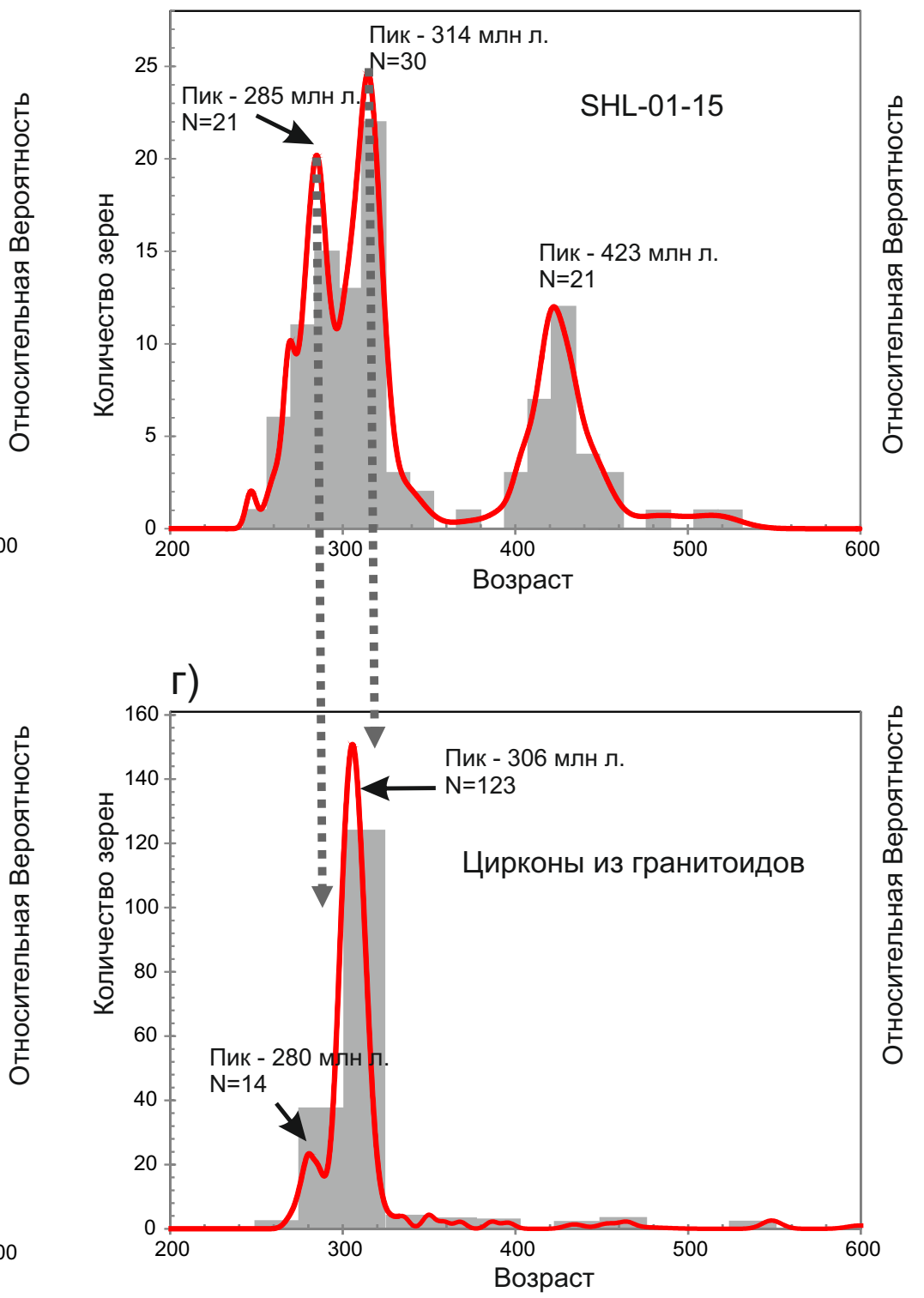




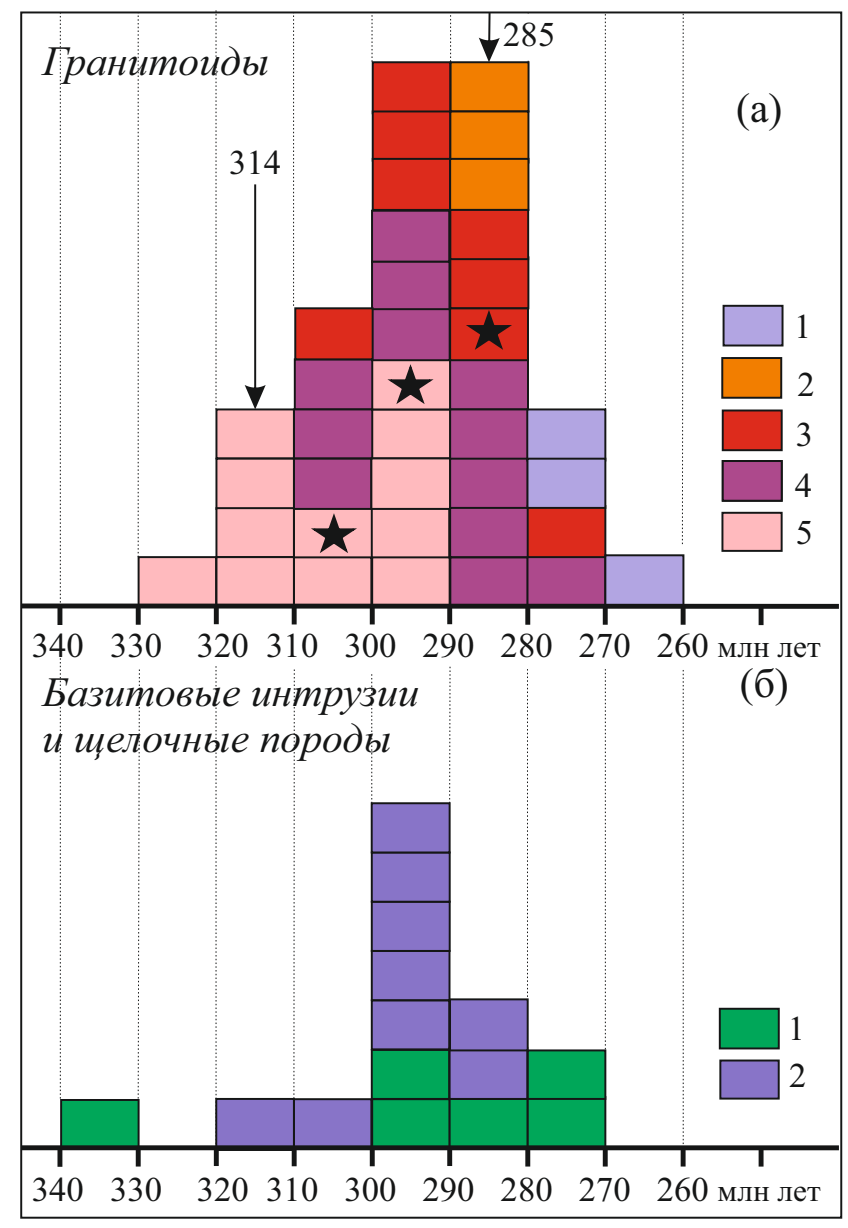


а) Поздний карбон

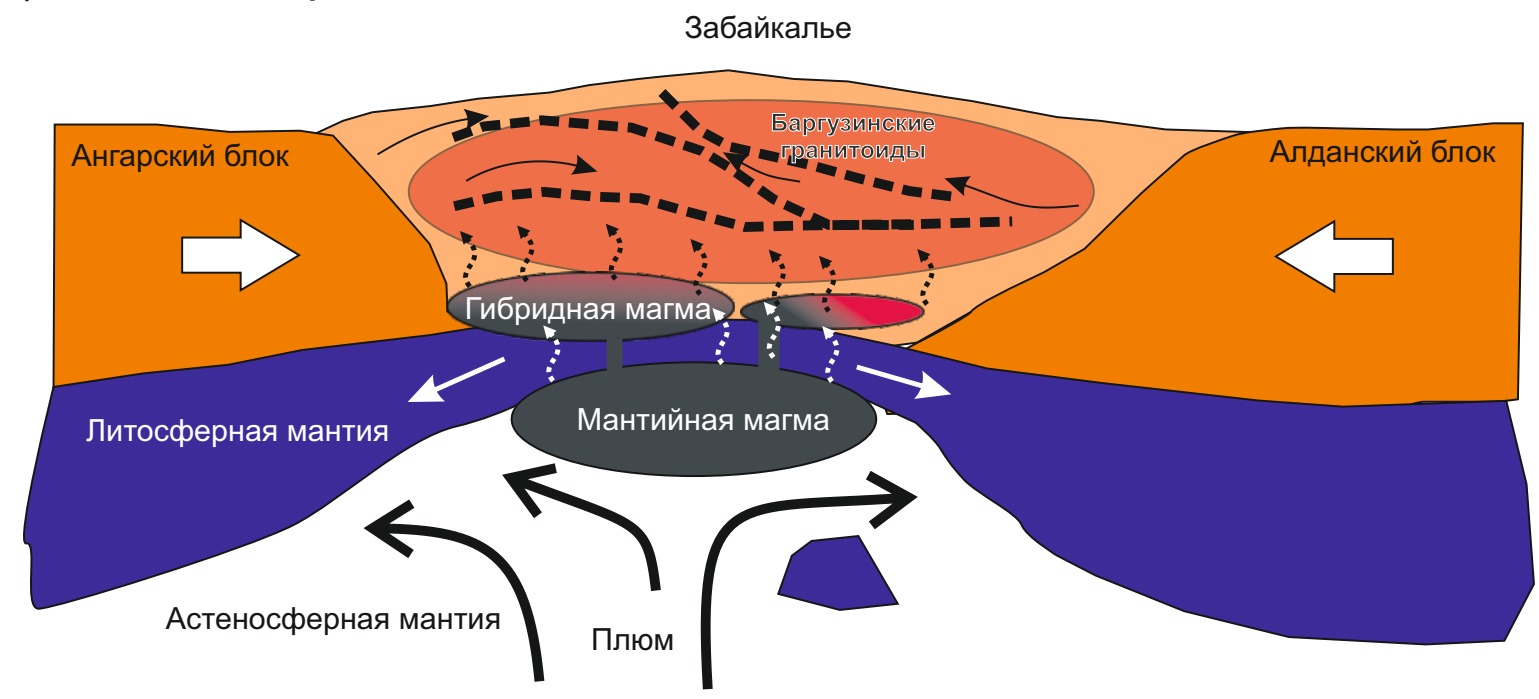

б) Поздний карбон - ранняя пермь

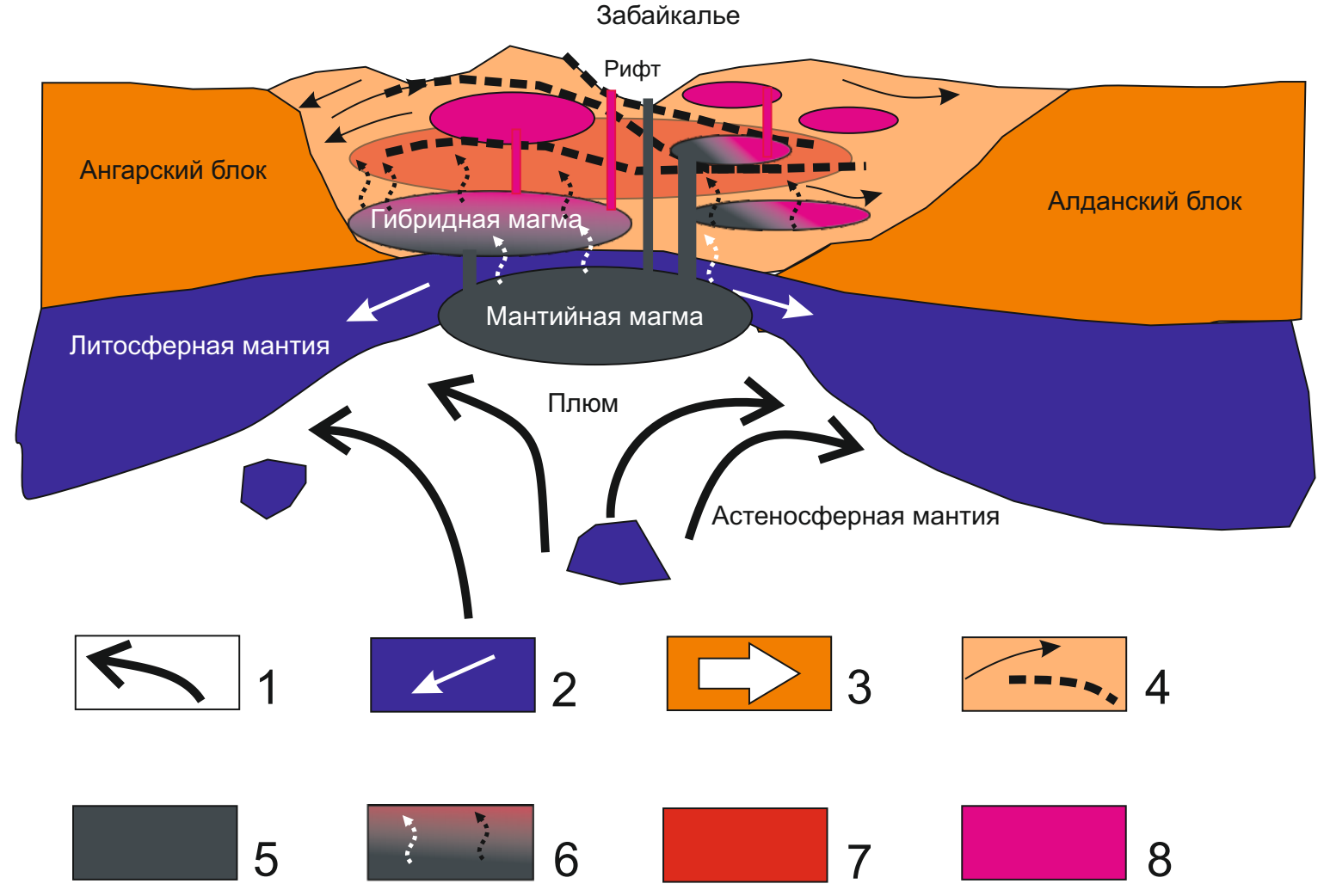

